Aline Duarte da Graça Rizzo

Entre o Desenvolvimento e a Segurança: Cooperação Sul-Sul entre Brasil e Líbia nos governos Lula e Dilma

Dissertação de Mestrado

Dissertação apresentada como requisito parcial para obtenção do título de Mestre pelo Programa de Pós-graduação em Relações Internacionais do Instituto de Relações Internacionais da PUC-Rio.

Orientadora: Prof. Adriana Erthal Abdenur

Rio de Janeiro

Fevereiro de 2015 


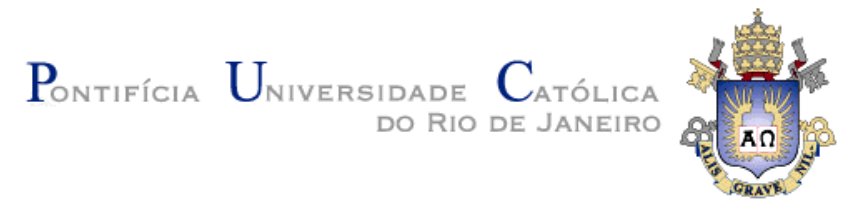

Aline Duarte da Graça Rizzo

\section{Entre o Desenvolvimento e a Segurança: Cooperação Sul-Sul entre Brasil e Líbia nos Governos Lula e Dilma}

Dissertação apresentada como requisito parcial para obtenção do título de Mestre pelo Programa de Pós-Graduação em Relações Internacionais do Instituto de Relações Internacionais da PUC-Rio. Aprovada pela Comissão Examinadora abaixo assinada.

Profa. Adriana Erthal Abdenur Orientadora e Presidente Instituto de Relações Internacionais - PUC-Rio

Profa. Paula Orrico Sandrin Instituto de Relações Internacionais - PUC-Rio

Profa. Monique Sochaczewski Goldfeld Escola de Comando e Estado Maior do Exército - ECEME

Profa. Monica Herz Vice-Decana de Pós-Graduação do Centro de Ciências Sociais - PUC-Rio

Rio de Janeiro, 25 de Fevereiro de 2015. 
Todos os direitos reservados. É proibida a reprodução total ou parcial do trabalho sem autorização da universidade, da autora e do orientador.

\section{Aline Duarte da Graça Rizzo}

Bacharela e licenciada em História pela Universidade Federal do Rio de Janeiro - UFRJ (2012). Atua como tutora presencial de História Moderna I e Moderna II do curso de licenciatura em História da Universidade Federal do Estado do Rio de Janeiro -UniRio juntamente com o Consórcio de Ensino á Distância do Estado do Rio de Janeiro-CEDERJ. Em 2014 atuou como Visiting Research Fellow no Departamento de Ciência Política da Brown University nos EUA. Tem interesse nas áreas de História Moderna e Contemporânea, Cooperação Internacional e Desenvolvimento.

Ficha Catalográfica

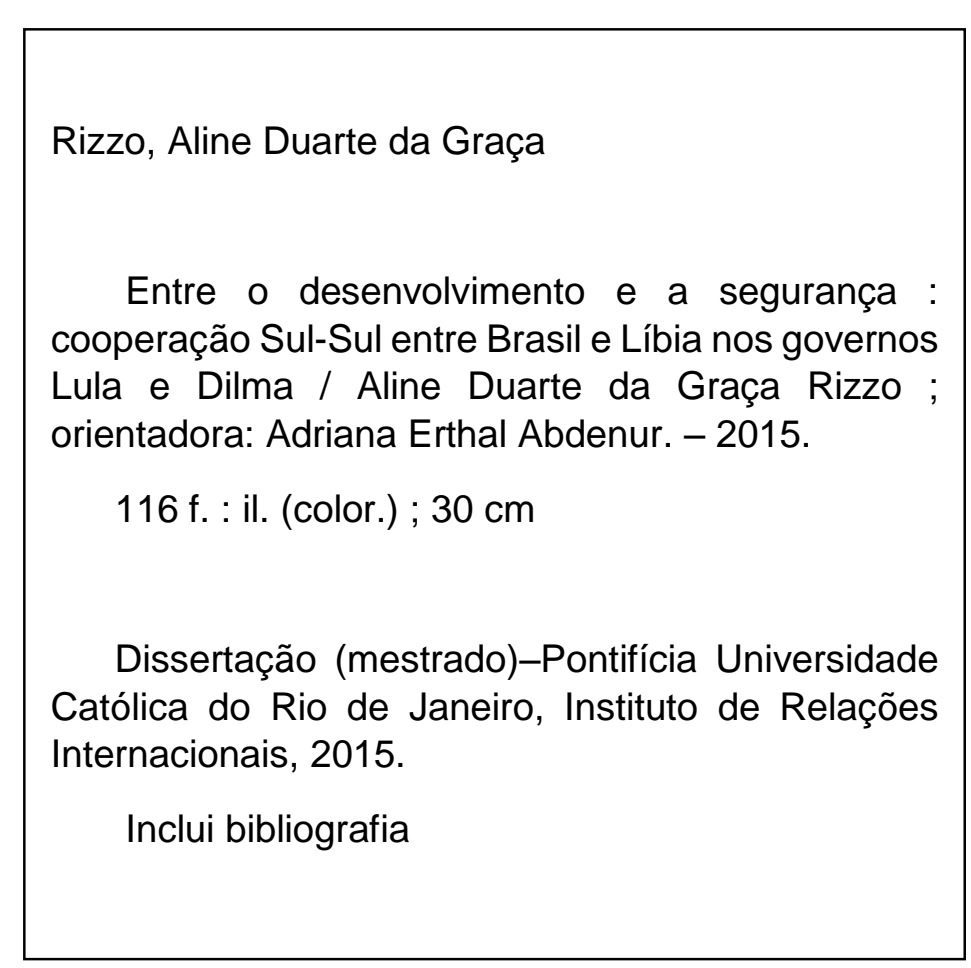

CDD: 327 


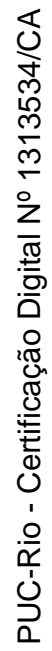

Aos meus pais, Jorge e Regina, e ao meu esposo Fabiano. 


\section{Agradecimentos}

Primeiramente e publicamente agradeço a Deus por ter me sustentado até aqui.

Aos meus pais Jorge e Regina pelo investimento e dedicação à minha carreira profissional e aos meus irmãos Priscila e Josué que me fazem ver a vida de forma mais leve.

Ao meu amado esposo Fabiano por ter dividido comigo cada momento desta caminhada. Por ter chorado o meu choro e sorrido o meu sorriso. Pelo investimento, paciência e companheirismo nos três meses de afastamento em prol da pesquisa.

Aos amigos queridos que por tantos momentos se fizeram suporte e incentivo. Em especial aos que tiveram participação direta na pesquisa: Anna Luiza Somner, Marcella Albaine, Rafaella Peres, Alessandra Sias e Anelise Gondar.

À minha orientadora Adriana Abdenur por todo apoio, amizade e pelas preciosas contribuições a esta pesquisa. Por ter acreditado no meu trabalho quando eu mesma não podia fazê-lo.

Aos amigos e colegas de turma de mestrado do IRI/PUC-Rio companheiros diários desta jornada.

Aos professores e funcionários do IRI/PUC-Rio por todo suporte e em especial aos professores Kai Kenkel e Letícia Pinheiro pelo constante apoio e à Lia pelo cuidado e atenção.

Às professoras componentes da banca examinadora e de qualificação pelas ricas contribuições à pesquisa.

À CAPES - Coordenação de Aperfeiçoamento de Pessoal de Nível Superior bem como à PUC-Rio pelo o auxílio concedido sem o qual este trabalho não poderia ter sido realizado.

À Brown University juntamente com a CCCI PUC-Rio-Coordenação Central de Cooperação Internacional pela concessão da bolsa de Visiting Research Fellow que me permitiu durante três meses pesquisar aspectos fundamentais desta dissertação. Ao Political Science Department pela calorosa recepção e à professora Melani Cammett pela precisa orientação. 


\section{Resumo}

Rizzo, Aline Duarte da Graça; Abdenur, Adriana Erthal. Entre o Desenvolvimento e a Segurança: Cooperação Sul-Sul entre Brasil e Líbia nos governos Lula e Dilma. Rio de Janeiro, 2015. 116p. Dissertação de Mestrado - Instituto de Relações Internacionais, Pontifícia Universidade Católica do Rio de Janeiro.

Nas últimas décadas a Cooperação Sul-Sul tem se intensificado substancialmente acompanhando o processo de crescente atuação das "potências emergentes" no cenário internacional pós Guerra Fria. Tal intensificação tem gerado debates na disciplina das Relações Internacionais acerca do papel desses atores com importante destaque à observância dos desafios pertinentes às agendas de desenvolvimento e segurança cada vez mais convergentes. Nesse sentido, esta dissertação tem por objetivo central analisar a Cooperação Sul-Sul entre o Brasil e a Líbia durante os governos Lula e Dilma estabelecendo assim o recorte temporal que se inicia em 2003 e que se estende até 2014. Este recorte será dividido em dois momentos tendo como marco de inflexão fundamental o ano de 2011 quando ocorreu a Primavera Árabe e a subsequente intervenção da OTAN na Líbia bem como a transição de governos entre Lula e Dilma no Brasil. Esse momento é marcado pelos debates acerca da Responsabilidade de Proteger (R2P), princípio implementado pela primeira vez no caso da Líbia, e a crítica brasileira seguida da proposta de formulação da Responsabilidade ao Proteger (RwP). Portanto, será dado destaque à observação da política externa brasileira e os esforços do Brasil de inserção no cenário internacional enquanto potência regional e poder global emergente compreendendo este movimento sob a perspectiva da interseção entre políticas de desenvolvimento e segurança. Esta pesquisa insere-se no marco teórico do recente debate no campo das Relações Internacionais denominado securitydevelopment nexus debate esse motivado pelos desdobramentos do evento de 11 de 
setembro e da subsequente "Guerra ao Terror" e que mobiliza discussões acerca da convergência dos campos da segurança e do desenvolvimento no atual cenário internacional. Desse modo, argumenta-se que há uma dinâmica conflitiva e crescente na política externa brasileira que alterna contestação do e inserção no sistema internacional. Essa dinâmica permeia as relações do Brasil com a Líbia bem como o posicionamento brasileiro no que tange às agendas de desenvolvimento e segurança.

\section{Palavras-chave}

Cooperação Sul-Sul; Brasil; Líbia; Nexo Segurança-Desenvolvimento 


\section{Abstract}

Rizzo, Aline Duarte da Graça; Abdenur, Adriana Erthal (Advisor). Between Development and Security: South-South Cooperation between Brazil and Libya in Lula and Dilma governments Rio de Janeiro, 2015. 116p. MSc. Dissertation - Instituto de Relações Internacionais, Pontifícia Universidade Católica do Rio de Janeiro.

In the last decades, the South South Cooperation has intensifying substancially following the process of increase role of the "emerging powers" on the international scene after Cold War. This intensification has improve the debate in International Relations discipline about the role of this players with focus on the challenges of development and security agenda convergence. In this sense, this dissertation has main goal to analyse the South-South Cooperation between Brazil and Libya in the Lula and Dilma governments setting the time frame that begins in 2003 and extends until 2014. This period will be divided in two moments with fundamental inflection point in 2011when happened the Arab Spring and the subsequente NATO intervention in Libya as well as the transition between Lula and Dilma government. This moment is marked for Responsability to Protect (R2P) debates in International Relations discipline, a principle implemented for the first time in the Libya case, and the Brazilian critics following for the Responsability while Protecting (RwP) proposal. Therefore, emphasis will be placed on Brazilian foreign policy and the Brazil efforts to insertion on international scene as a regional power and emerging global power understending this movement under the development and security policies intersection perspective. This research is based on recently theorical framework of International Relations field called securitydeveloment nexus. This debate was motiveted for 9/11 events and the "Terror War" as well as to mobilize the discussion about security and development fields 
convertion. In this sense, it will be argued that there is a conflitive and increase dynamics in Brazilian foreign policies that alternates contestations of and insertion on international sistem. This dynamics permeates the relations between Brazil na Libya as well as the brazilian position about development and security agendas.

\section{Keywords}

South-South Cooperation; Brazil; Libya; Security-Development Nexus 


\section{Sumário}

1.Introdução

2.Potências Emergentes e o Nexo Segurança-Desenvolvimento

2.1 O Nexo Segurança - Desenvolvimento

2.2 As Potências Emergentes e o Nexo - contribuições das potências emergentes para o debate

2.3 O Brasil e o Nexo

2.4 Conclusão

3.1 Líbia Independente

3.2 Relações Brasil e Líbia entre 1969 e 2002: um panorama

4.As Relações Brasil e Líbia nos governos Lula e Dilma sob a perspectiva do Nexo Segurança-Desenvolvimento 
$\begin{array}{ll}\text { 4.3 O Ouro Negro e as Empreiteiras } & 78\end{array}$

4.4 Governo Dilma e a Era pós Kadaffi 82

4.5 O Brasil e o Nexo no caso da Cooperação com a Líbia 92

$\begin{array}{ll}\text { 4.6 Conclusão } & 96\end{array}$

5.Considerações Finais $\quad 99$

6.Referências Bibliográficas 105 


\section{Lista de Figuras}

Figura 1 - Ernesto Geisel, Shigeaki Ueki, $\quad 55$

Araken de Oliveira e outros por ocasião da visita do ministro do petróleo da Líbia

Figura 2 - Gráfico de fluxo comercial entre Brasil e Países Árabes $\quad 68$

Figura 3 - Importação Brasil-Países Árabes 2011

Figura 4 - Exportação Brasil-Países Árabes 2011 


\section{Siglas}

ABC - Agência Brasileira de Cooperação

ANBA - Agência de Notícias Brasil Árabe

ASPA - Cúpula America do Sul-Países Árabes

BRICS - Brasil, Russía, Índia, China e África do Sul

CEDPEN - Centro de Estudos e Defesa do Petróleo

CNT - Conselho Nacional de Transição

CSS - Cooperação Sul-Sul

CTPD - Cooperação Técnica para o Desenvolvimento

GATT - Acordo Geral de Tarifas e Comércio

LEA - Liga dos Estados Árabes

MDIC - Ministério do Desenvolvimento, Indústria e Comércio Exterior

MINUSTAH - Missão das Nações Unidas Para Estabilização no Haiti

MRE - Ministério das Relações Exteriores

ONU - Organização das Nações Unidas

OTAN - Organização do Tratado do Atlântico Norte

OPEP - Organização dos Países Exportadores de Petróleo

PEB - Política Externa Brasileira

PT - Partido dos Trabalhadores 
R2P - Responsabilidade de Proteger

RwP - Responsabilidade ao Proteger

UNASUL - União de Nações Sulamericana

Duas lentes escuras curvavam-se como corcova de uma tartaruga por cima dos seus olhos. O céu, o sol, e o mar eram pintados por Deus em cores que podíamos identificar e dizer o mar é turquesa, o sol é cor de banana, o céu é azul. Óculos escuros são terríveis, eu pensava, porque modificam tudo isso e mantêm à distância quem os usa.

Hisham Matar, No País do Homens. São Paulo: Companhia das Letras, 2007 


\section{Introdução}

O cenário internacional pós Guerra Fria é marcado por uma transição na direção de maior multipolaridade e pela evidência de atores cuja margem de ação era outrora limitada pelo sistema bipolar então vigente. Tais transformações suscitaram importantes desafios à disciplina das Relações Internacionais à medida que novos atores estatais se articulam em novos arranjos que desafiam o status quo além da própria contestação à noção moderna de Estado Soberano e crescente fluidez de suas fronteiras.

É nesse contexto que surgem os debates acerca das então denominadas "potências emergentes" entendidas enquanto estados que têm apresentado notável fortalecimento de suas economias ao mesmo tempo em que contestam a atual governança global (Ikenberry e Wright, 2008). Tal contestação se dá fortemente no campo do desenvolvimento onde é possível observar nas últimas décadas um importante movimento de cooperação internacional: a intensificação da Cooperação Sul-Sul.

Atores estatais periféricos que anteriormente eram alvos de ajuda internacional, ou seja predominantemente recipiendários, ampliam seus esforços passando a oferecer mais assistência do que recebem em uma nova proposta de cooperação que se pretende horizontalizada e não hierarquizada. Trata-se da promoção de desenvolvimento através da ajuda mútua entre estados do Sul Global que contesta e desafia as estruturas econômicas, políticas, sociais e culturais ampliando e diversificando os fluxos de trocas comercias e expertise bem como estabelecendo novas relações com atores cada vez mais diversos. É certo que não se trata de uma inovação da virada do século, mas nas últimas décadas é observado crescente fluxo da Cooperação Sul-Sul que tem chamado à atenção e obtendo cada vez maior espaço nos debates acadêmicos (Mawdsley, 2012). 
Não apenas a agenda de desenvolvimento, mas também o campo da segurança tem se modificado diante das transformações oriundas do cenário internacional cada vez mais heterogêneo. O contexto pós Guerra Fria além de maior multipolaridade é caracterizado por conflitos intra-estatais e pelo incremento das intervenções de cunho humanitário. Busca-se legitimar tais intervenções através do discurso em que estados "incapazes" de proteger seus civis e garantir os direitos humanos a sua população não exercem, por esse motivo, sua soberania em plenitude e, portanto, seriam alvos legítimos de intervenção externa. (Bellamy, 2009).

As intervenções humanitárias contemporâneas são caracterizadas por serem multidimensionais, pois as ações não se concentram unicamente na paralização do conflito, mas também objetivam fomentar a "construção do estado" peacebuilding através do desenvolvimento. O modelo de desenvolvimento empregado nessas operações tem fortes matizes liberais ao que convencionou-se chamar Paz Liberal (Richmond, 2006).

Nesse sentido, o atual cenário internacional revela importante relação entre os campos do desenvolvimento e segurança especialmente após os ataques do 11 de setembro que catalisaram um crescente processo de securitização da agenda de desenvolvimento (Stern e Ojendal, 2010). Isso quer dizer que está em curso uma progressiva securitização da segurança internacional e que os esforços na promoção do desenvolvimento se concentram em atender prioritariamente a agenda de segurança.

O Brasil enquanto potência emergente tem exercido relevante papel no âmbito da Cooperação Sul-Sul para o desenvolvimento bem como na arena da segurança internacional sobretudo durante os mandados do presidente Luiz Inácio Lula da Silva (2003-2011), apresentando um posicionamento crítico ao processo de securitização do desenvolvimento descrito por Duffiled (2010). O caso específico da cooperação entre Brasil e Líbia será analisado à luz da interseção entre os campos do desenvolvimento e da segurança com foco nos governos de Lula, onde observouse grande ênfase na Cooperação Sul-Sul, e de Dilma Rouseff (2011-2015) onde mediante os desdobramentos da Primavera Árabe na Líbia observa-se importante ponto de inflexão.

O objeto desta pesquisa, portanto, é a Cooperação Sul-Sul estabelecida entre o Brasil e a Líbia e as questões relativas a desenvolvimento e segurança que permeiam tal cooperação. O recorte temporal aqui delimitado se concentra em dois 
momentos do governo do Partido dos Trabalhadores (PT) no Brasil: o primeiro tem início em 2003 quando Lula, cuja política externa é considerada pró-ativa e pragmática (Hirst, Lima e Pinheiro, 2010), assume a presidência e se estende ao fim de seu segundo mandato em 2010. O segundo momento compreende a gestão de sua sucessora Dilma Rouseff que assume a presidência em 2011, ano em que há um marco fundamental que é a intervenção da OTAN na Líbia, e se estende ao seu segundo mandato iniciado em 2015 e ainda vigente.

A política externa brasileira (PEB) é historicamente marcada pelo discurso de defesa da soberania e da não-intervenção. Tal posicionamento por vezes evidencia o ponto de inflexão estabelecido entre a defesa da soberania e a defesa dos direitos humanos, ambas definidas pela constituição de 1988. Os novos desafios de inserção brasileira enquanto potência emergente no cenário internacional revelam tal inflexão gerando discursos e práticas que estão em constante tensão.

O recente caso da intervenção da OTAN na Líbia, no ano de 2011, em decorrência dos conflitos políticos travados no contexto da Primavera Árabe traz à tona a discussão sobre a legitimidade das intervenções e, neste caso em especial, sobre o princípio da Responsabilidade de Proteger (R2P), pela primeira vez implementado. O posicionamento do Brasil, sua abstenção de voto referente à resolução 1973 que deflagra a ação na Líbia e sua crítica à implementação da R2P acompanhada de uma proposta de perspectiva alternativa, a Responsabilidade ao Proteger (RwP), são emblemáticos para compreendermos a tensão estabelecida entre soberania e direitos humanos na política externa brasileira.

Em um primeiro olhar podemos compreender facilmente a oposição brasileira à ação da OTAN, pois evoca a defesa da soberania, marca histórica não somente da política externa brasileira, mas também dos países que compõem o Sul Global. No entanto, será esse o único motivo para a crítica brasileira à intervenção na Líbia? Desde a década de 1970 o Brasil tem relações com a Líbia para além da diplomacia. É possível observar importante cooperação entre os dois estados que compreende desde trocas comerciais na década de 1970, com importante destaque à exploração de petróleo, aos projetos de cooperação técnica na área da saúde, investimentos de empresas públicas e privadas na área de infraestrutura que se intensificaram nos últimos dez anos além de cooperação política na transição de regime na Líbia pós-intervenção. 
Nesse sentido, a questão central que norteará esta pesquisa é: Em que medida a cooperação para o desenvolvimento oferecida à Líbia pelo Brasil corresponde ao discurso oficial da diplomacia brasileira no que diz respeito às intervenções humanitárias? Dessa questão fundamental decorrem questões secundárias tais como: Como a política externa brasileira concebe, mobiliza e articula o nexo Desenvolvimento-Segurança? Como a política externa brasileira em relação à Líbia tem se transformado ao longo de tal marco temporal? Quais os interesses econômicos e políticos por parte do Brasil na Líbia que são despolitizados no argumento RwP? Estas são os principais questionamentos que mobilizam este trabalho.

A hipótese desta dissertação é a de que a crítica do Brasil à intervenção da OTAN na Líbia não se restringe à crítica da implementação da Responsabilidade de Proteger. Existe interesses por parte do Brasil na Líbia que são despolitizados sob o discurso humanitário de crítica à intervenção. A despeito do ensaio de elaboração dos princípios da Responsabilidade ao Proteger existe desde longa data cooperação sobretudo econômica entre Brasil e Líbia e portanto, o posicionamento brasileiro neste caso não deve ser observado unicamente à luz de questões humanitárias e de segurança. Nesse sentido, há uma dinâmica conflitiva e crescente na política externa brasileira que alterna contestação do e inserção no sistema internacional. Essa dinâmica permeia as relações do Brasil com a Líbia bem como o posicionamento brasileiro no que tange às agendas de desenvolvimento e segurança.

Embora o Brasil recentemente tenha demonstrado fortes ambições de se tornar um ator mais relevante no cenário internacional a PEB tem sustentado um discurso de ênfase na agenda de desenvolvimento, onde há maior potencial de agência, em detrimento da agenda de segurança onde sua margem de ação é consideravelmente limitada. É evidenciado, nesse estudo de caso, não somente a ênfase da política externa brasileira na prevenção de conflitos, mas principalmente em dar enfoque e se movimentar no contexto da agenda Sul-Sul de desenvolvimento, onde sua margem de ação é seguramente maior.

Neste sentido, este trabalho tem por objetivo central analisar a Cooperação Sul-Sul entre o Brasil e a Líbia no recorte temporal que se inicia em 2003 e que se estende aos dias atuais. Será dado destaque à observação da política externa brasileira e os esforços do Brasil de inserção no cenário internacional enquanto 
potência regional e poder global emergente compreendendo este movimento sob o marco da interseção entre políticas de desenvolvimento e segurança. Para tal, foram traçados objetivos específicos, tais quais: mapear e delimitar as frentes de cooperação estabelecida entre Brasil e Líbia e os atores envolvidos; observar as transformações da política externa brasileira no período compreendido no recorte temporal proposto; analisar como o Brasil enquanto potência emergente entende a relação entre desenvolvimento e segurança; e identificar os interesses econômicos e geopolíticos envolvidos na relação Brasil e Líbia.

Esta pesquisa se justifica por pretender preencher lacunas de ordem teórica e empírica. Da perspectiva teórica as críticas ao discurso da securitização da agenda do desenvolvimento e à Paz Liberal estão focadas nas motivações dos países do Norte e sua inserção nos países do Sul Global. Há muito pouco acerca das motivações da inserção de potências emergentes em outros estados e portanto da observância do nexo segurança-desenvolvimento na perspectiva do Sul, existe uma literatura que contempla a percepção das potências emergentes no que diz respeito à intervenção, no entanto ainda são poucos os trabalhos nesse sentido e a discussão precisa ser melhor elaborada Este trabalho se propõe a um esforço teórico nesse sentido.

Da perspectiva empírica a literatura até então produzida sobre a Cooperação Sul-Sul estabelecida entre o Brasil e o continente africano têm se concentrado nas relações do país com estados da região da África Subsaariana, especialmente com estados de língua portuguesa. Os estudos acerca das relações entre o Brasil e os países do Norte da África são escassos, no entanto, desde a década de 1970 são observados movimentos de cooperação entre o Brasil e a Líbia. Este trabalho, portanto, é um esforço de contribuição para o debate complementando a literatura já existente sobre a inserção brasileira na região subsaariana.

O caso da cooperação Brasil-Líbia é especialmente importante, pois revela questões pertinentes ao papel almejado pelos países em desenvolvimento no cenário da política mundial. É igualmente pertinente destacar sua relevância mediante aos recentes conflitos políticos na Líbia, que deixa de ser um estado páreo para ser alvo de intervenção.

Esta pesquisa insere-se no marco teórico do recente debate no campo das Relações Internacionais acerca do nexo segurança-desenvolvimento. O contexto pós Guerra Fria, marcado pelos conflitos intra-estatais e incremento de intervenções 
de cunho humanitário, suscitou discussões acerca da convergência dos campos da segurança e do desenvolvimento que culminaram no recente debate denominado security-development nexus. As discussões teórico-epistemológicas acerca do security-development nexus foram motivadas pelos desdobramentos do evento de 11 de setembro e da subsequente "Guerra ao Terror". Os principais autores inseridos nesse debate cuja contribuições irão compor o quadro teórico desta dissertação são David Chandler (2007), Maria Stern e Joakim Ojendal (2010), Mark Duffield (2010) e Simon Reid-Henry (2011). Além desses autores serão incluídos trabalhos que buscam analisar o nexo a partir da perspectiva das "potências emergentes" como Adriana Abdenur e Danilo Marcondes (2014).

Para aprofundar tal discussão serão revistados os trabalhos acerca da Paz Liberal e suas críticas no intuito de agregar movimentos anteriores ao debate security-development nexus, mas que trazem à tona a análise da relação entre desenvolvimento e segurança em situações de conflitos. Dentre eles, destacam-se os trabalhos de Mark Duffield (2001, 2007), Oliver Richmond (2006), Roland Paris e Timothy Sisk (2009) e Roland Paris (2011).

Acerca da Cooperação Sul-Sul cabe ressaltar que este é um tema subteorizado no campo das Relações Internacionais. Nos últimos anos é observado um aumento de fluxo dessa forma de cooperação e consequentemente o interesse por estudos relacionados a esse tema somente foi despertado recentemente, é um tema que portanto carece de definição teórica e conceitual robusta. Os trabalhos que se caracterizam por esforços nesse sentido aqui privilegiado são de Elodie Brun (2008) Iara Leite (2010), Emma Mawdsley (2012). Além disso, serão minimente revisitados trabalhos anteriores ao movimento de Cooperação Sul-Sul mas que tratam de alianças e cooperação internacional como Robert Keohane (1984), Kenneth Waltz (1986) e Samir Amin (1990).

E por fim, será enfatizado o também recente debate no campo das Relações Internacionais sobre Responsabilidade de Proteger (Responsability to Protect R2P) e Responsabilidade ao Proteger (Responsability while Protecting - RwP). O princípio da Responsabilidade de Proteger visa balizar os termos da intervenção com o uso da força em situações de conflito. É utilizado pela primeira vez no caso da intervenção da OTAN na Líbia em 2011 quando o Brasil se posiciona de forma crítica à sua implementação propondo a elaboração da Responsabilidade ao Proteger visando esgotar os últimos recursos possíveis antes da intervenção. Os 
trabalhos em destaque são Alex Bellamy (2009), Kai Kenkel (2012), Thorsten Benner (2013), Eduarda Harmann e Robert Muggah (2013).

Este é um estudo de caso onde será adotado o método qualitativo a partir da triangulação de dados tais como fontes governamentais; informações de agências de notícias em mídia eletrônica; e dados de organizações e instituições de pesquisa. Além desse conjunto documental foi proposta a elaboração de entrevistas com representantes de instituições públicas e privadas envolvidas em projetos de cooperação nos dois estados.

Cabe ressaltar que apesar de ser um trabalho de análise que se concentra na perspectiva brasileira, por se tratar de uma relação bilateral, buscou-se agregar fontes e autores líbios, não obstante as limitações impostas pela língua e pelo próprio contexto de instabilidade política da região que se reflete no acesso à informação. Também é importante destacar que neste trabalho a Líbia não é referida como pertencente ao Oriente Médio. O projeto norte-americano de aumentar influência nas regiões produtoras de petróleo nos últimos anos inclui no que denominou-se de "Grande Oriente Médio" as regiões do norte da África, dentre elas a Líbia ${ }^{1}$ O livro organizado por Paul Amar (2014) intitulado "The Middle East and Brazil" traz importantes dados e reflexões sobre as relações entre Brasil e Líbia, porém não problematiza a questão também incluindo a Líbia no leque relações Brasil e Oriente Médio. Como o petróleo também será fator fundamental nas relações bilaterais entre Brasil e Líbia, nos momentos em que estiverem incluídas em políticas brasileiras comuns para as duas regiões será utilizada a referência "Norte da África e Oriente Médio".

Esta dissertação divide-se em três capítulos além da introdução e conclusão. No primeiro capítulo será apontado e debatido o marco teórico no qual este trabalho se insere, ou seja, o debate security-development nexus. Inicialmente serão apresentadas as ideias dos principais autores que discutem o nexo no campo das Relações Internacionais. Em seguida, serão analisadas as contribuições das potências emergentes para o debate e inseridas as discussões acerca da Cooperação Sul-Sul para o desenvolvimento. Por fim, será explanada a relação da política

\footnotetext{
${ }^{1}$ HAERI, Safa. Asia Times Online. Disponível em: http://www.atimes.com/atimes/Middle_East/FC04Ak06.html Acessado em: 03 de fevereiro de 2015.
} 
externa brasileira com o nexo segurança desenvolvimento com ênfase nos recentes debates acerca da Responsabilidade de Proteger e Responsabilidade ao Proteger.

No segundo capítulo há uma contextualização histórica das relações entre o Brasil e a Líbia objetivando apontar que apesar do grande impulso das relações entre ambos durante o governo Lula tais relações tem um percurso maior, de longa data, dando seus primeiros passos significativo na década de 1970 ainda durante a ditadura civil-militar no Brasil. Serão apresentados também os processos e dinâmicas internas da Líbia desde sua independência apontando seu potencial comercial no campo petrolífero. Essa contextualização é acompanhada de uma análise das transformações da política externa brasileira ao longo do período compreendido entre 1969 e 2002. Foi observado nessa análise que as relações Brasil e Líbia não obedeceram um continuum, mas ao contrário, foram caracterizadas por movimentos ora de encontros, ora de desencontros.

O terceiro capítulo dedica-se a análise das Cooperação Sul-Sul Brasil e Líbia durante o governo Lula e Dilma, período compreendido entre 2003 e 2014 tendo um ponto de inflexão fundamental no ano de 2011 marcado pelos desdobramentos da Primavera Árabe na Líbia culminando na intervenção da OTAN, bem como pela transição de governos no Brasil entre Lula e Dilma que trouxe significativas mudanças na condução da política externa brasileira. Será privilegiada a análise de como o Brasil articula o nexo segurança-desenvolvimento no âmbito da Cooperação Sul-Sul e a partir das discussões acerca da Responsabilidade de Proteger e Responsabilidade ao Proteger tendo como catalizador a intervenção da OTAN na Líbia. Por fim, nas considerações finais serão apresentadas possíveis respostas para a questão central da presente pesquisa bem como possíveis conclusões e recomendações futuras para aprofundamento do tema. 


\section{Potências Emergentes e 0 Nexo Segurança- Desenvolvimento}

O contexto pós 11 de setembro mobilizou importante discussão no campo das Relações Internacionais à qual denominou-se security-development nexus. Tal debate busca compreender o processo de securitização da agenda de desenvolvimento em curso no atual cenário internacional marcado pelo intervencionismo. $\mathrm{O}$ foco das discussões se direcionam para a forma pela qual se articula a segurança e o desenvolvimento em situações de intervenção em geral promovida pelos países do Norte Global em países do Sul Global.

A atuação cada vez mais evidente das potências emergentes no cenário internacional reivindicando novos espaços bem como reforma da governança global tem suscitado o interesse em se observar como o papel dos países emergentes tem se modificado no contexto do nexo segurança-desenvolvimento. Tem se questionado como esses países atuam e se engajam em situações de conflito e instabilidade em outros estados. Neste capítulo será examinada a trajetória do debate teórico acerca do nexo entre segurança e desenvolvimento enfatizando a contribuição da perspectiva das potências emergentes para a discussão.

Como a política externa brasileira concebe, mobiliza e articula o nexo Segurança-Desenvolvimento? Para a compreensão das relações entre o Brasil e a Líbia será utilizada a literatura de Relações Internacionais voltada para a análise do nexo. Portanto, objetiva-se examinar as possíveis relações entre os dois campos e seus limites explicativos para o caso em questão.

Diante da diversidade de possibilidades de interseção entre Segurança e Desenvolvimento será definido aqui o marco no qual tal nexo é compreendido a partir da lógica da intervenção. Nesse sentido, primeiramente serão apresentados os principais debates desde as discussões acerca da Paz Liberal aos mais atuais esforços em conjugar os dois campos.

Na primeira seção serão apresentados os principais debates da literatura das Relações Internacionais no que tange ao nexo. Em seguida serão analisadas as 
contribuições das potências emergentes para esse debate e por fim, será examinado o posicionamento brasileiro a respeito do nexo.

\section{1}

\section{O Nexo Segurança-Desenvolvimento}

O contexto pós Guerra Fria além da multipolaridade é caracterizado por conflitos intra-estatais e pelo incremento das intervenções de cunho humanitário capitaneadas. Tal cenário internacional traz à tona o debate da Paz Liberal, tanto no ambiente acadêmico quanto político, agora compreendido à luz do contexto de intervenção e pós-conflito avançando as contribuições de Locke e Kant (Doyle, 1983).

Em linhas gerais a Paz Liberal é definida como uma combinação de democracia, direitos humanos, livre mercado, rule of law e desenvolvimento nos parâmetros neoliberais. A crítica em torno da Paz Liberal basicamente questiona a transplantação desse modelo de "Paz" que é ocidental e eurocêntrico para países periféricos em situações de peacebuilding.

Segundo Oliver Richmond (2006), os discursos a respeito da Paz Liberal podem ser ordenados em três principais grupos: conservador, ortodoxo e emancipatório. O primeiro discurso se aproxima da abordagem do peacebuilding e do desenvolvimento estabelecidos através do uso da força; o modelo ortodoxo é sensível à realidade local, com suas diferenças culturais, mas ainda assim propõe a transferência de um método eurocêntrico, que nesse caso deve ser implementado a partir da negociação consensual; e por fim, o último discurso denomina-se emancipatório e é a abordagem mais crítica apontando a coercitividade, condicionalidade e dependência em que as perspectivas conservadoras e ortodoxas se assentam e traz preocupações referentes ao bem-estar social e à justiça. (Richmond, 2006, p.301).

As críticas à Paz Liberal podem ser direcionar a dois principais focos: crítica à implementação e crítica à legitimidade. No primeiro caso, não se questiona o modelo liberal de paz, mas sim a forma como ele tem sido implementado, muitas vezes se ignorando a realidade local. A proposta, portanto, seriam novas formas de execução que garantissem o sucesso da "transplantação" desse modelo. A crítica à legitimidade é mais profunda, pois se direciona à própria natureza da Paz Liberal 
apontando a imposição eurocêntrica de um determinado modelo que se pretende universal.

Um dos principais críticos da Paz Liberal, Roland Paris (Campbell et al., 2011), diferencia claramente peacebuilding de statebuilding definindo o primeiro como os esforços para a criação de condições em que a situação de guerra não seja retomada enquanto que o segundo objetiva construir instituições legítimas e efetivas que possibilitem o peacebuilding, se caracterizando portanto como um dos elementos deste. Sendo assim, em linhas gerais, a principal função do statebuilding é a promoção de: segurança, rule of law, serviços básicos, e ao menos um rudimentar plano de orçamento com coleta de impostos. Segundo o autor, nenhum desses elementos requer, em seu conceito de statebuilding, democracia ocidental ou uma ideologia de mercado neoliberal. Embora aponte que a democratização e mercantilização seja uma caraterística rotineira nas operações de peacebuilding. (Paris e Sisk, 2009)

Sua crítica consiste em apontar preocupação excessiva com liberalização política e econômica presente nas operações de paz. Há um movimento precoce de liberalização em ambientes de pós-conflito que na verdade deveria suceder a um processo anterior de institucionalização (Campbell et al. apud Paris, 2001).

Em contrapartida Mark Duffield (2001) defende que a Paz Liberal não se manifesta em uma única instituição de governança global, ao contrário, ela opera através de núcleos de autoridade dentro da governança liberal que traz consigo diferentes complexos estratégicos de atores estatais e não-estatais, civis e militares, públicos e privados o que inclui Organizações Não Governamentais, empresas de segurança dentre outros atores que buscam uma agenda radical de transformação social com finalidade de se alcançar a estabilidade global. A partir da concepção de biopolítica de Foucault, Duffield (2007;2010) propõe que existe um movimento de securitização da agenda de desenvolvimento em que desenvolvimento requer segurança e sem segurança não se pode ter desenvolvimento e que tal relação tem uma longa genealogia. A preocupação do autor é examinar o papel e função de tecnologias liberais em assegurar o "way of life" ocidental. Pressupondo o desenvolvimento como um discurso ocidental que se pretende universalizante Duffield busca compreender porque a problemática liberal da segurança domina o atual cenário político e como se operam dentro da arquitetura pós Guerra Fria o humanitarismo, desenvolvimento e o intervencionismo. Desse modo, o autor traz a 
perspectiva foucaultiana para a periferia do sistema internacional, antes sobre colonialismo, depois sobre migração.

Diante da longa genealogia entre tal nexo, Duffield não se questiona quanto a existência da interconexão entre desenvolvimento e segurança, mas sua questão central é o que há de novo nessa relação. Portanto, parte para a análise de dois movimentos contemporâneos: a contenção da migração espontânea e irregular e a reorientação do objeto de segurança: do estado para as pessoas que nele vivem (Duffield, 2010).

Dentro da lógica da intervenção, Duffiled elabora o conceito de soberania contingencial que é sinônimo de uma ordem de tecnologias liberais de segurança que, junto com seus mecanismos de coordenação estatais e não-estatais associados e a implementação de arranjos, estão de forma variada agindo na população para alterar mais uma vez a balança de poder entre grupos sociais, resolver conflitos, dar suporte em processos de paz ou reconstrução de sociedades. (Duffield, 2007). Ou seja, a soberania, pressuposto fundamental do Estado moderno, deixa de ser um valor absoluto e passa a ser equacionado mediante a capacidade ou não desse Estado exercer soberania. Um "Estado falido" portanto, diante de conflitos e crises humanitárias perde sua prerrogativa da soberania e a intervenção se torna "legítima". Portanto, a soberania é contingencial, e condicionada a capacidade do Estado de se auto gerir.

Nesse espaço é que operam as Organizações Não Governamentais (ONG's) em suas ações humanitárias. O mais importante não é destacar o espetacular crescimento do movimento internacional de ONG's desde 1950, mas sim interpretar esse crescimento como a internacionalização da gestão liberal que toma pessoas, direitos e liberdade como pontos de referência. Para as ONGs esse desenho de poder foi e ainda é premissa no estado de exceção entre pessoas não asseguradas popularmente conhecido como emergência humanitária. A emergência fornece um meio de penetração no mundo das pessoas, ignorando leis (direitos) existentes, convenções ou restrições; assim é permitida a colonização de novos estados ou o aumento da presença em pontos de apoio já existentes. Ou seja, é observado um processo de governamentalização da indústria da ajuda. (Duffield, 2007).

Nesse sentido, relativiza a ideia de fronteira e propõe que o desenvolvimento e subdesenvolvimento estabelecem uma zona de fronteira relacional e antropologicamente similar. Bem como as tecnologias de segurança, o 
desenvolvimento define exceções. A zona relacional que interconecta desenvolvimento e subdesenvolvimento é uma fronteira soberana. O autor argumenta que essa zona pode ser entendida como tendo tanto localização interna (metropolitana) e externa (ultramarina). Enquanto tecnologia de segurança o desenvolvimento interconecta as duas. Isso vai além da dicotomia nacional e internacional. (Duffield, 2007; 2010).

O contexto subsequente ao 11 de setembro de 2001 motivou o aprofundamento do debate teórico-epistemológico acerca do nexo entre segurança e desenvolvimento, o então denominado security-development nexus. Para Maria Stern e Joakim Ojendal (2010) a interseção entre Desenvolvimento e Segurança emerge do disparate ontológico existente entre os dois. A compreensão da relação entre os dois campos ontologicamente distintos requer recursos metodológicos interdisciplinares que sejam capazes de mapear as diversas possibilidades de nexo a partir de uma infinidade de narrativas.

Os autores então propõem um recurso metodológico que objetiva mapear as possíveis narrativas e discursos. Tal recurso é caracterizado pelo cruzamento das "histórias sobre o desenvolvimento" e as "histórias sobre segurança". As histórias sobre o desenvolvimento são classificadas como: Desenvolvimento como Narrativa Moderna (teleológica); Desenvolvimento Ampliado, Aprofundado e Humanizado; Desenvolvimento como Impasse; Pós-Desenvolvimento; Desenvolvimento como Governamentalidade e Desenvolvimento Globalizado. As histórias sobre segurança recebem a mesma classificação: Segurança como Narrativa Moderna (teleológica); Segurança Ampliada, Aprofundada e Humanizada e assim sucessivamente, com exceção da terceira categoria equivalente que se denomina Segurança como Impossível.

Cada uma das categorias é cruzada com sua correspondente: uma história sobre o desenvolvimento com uma história sobre a segurança equivalente. $\mathrm{O}$ resultado são seis categorias de narrativas sobre o nexo, a saber: Nexo Desenvolvimento/Segurança como Narrativa Moderna (teleológica), baseada na perspectiva ocidental de progresso; Nexo Desenvolvimento/Segurança Ampliado, Aprofundado e Humanizado, caracterizada por ambições complexas e combinações idealistas e normativas; Nexo Desenvolvimento/Segurança como Impasse/Impossível em que o nexo como atualmente é empregado se torna vazio, causando danos e desperdício de dinheiro; Pós segurança-desenvolvimento é 
semelhante à anterior com a diferença de que a ligação entre os dois campos é uma prática discursiva que opera como instrumento de poder; SegurançaDesenvolvimento como técnicas de Governamentalidade se baseia na noção de biopolítica de Foucault em que o nexo é uma técnica de biopoder através da qual a subjetividade, a imaginação e a vida são governadas; e por fim a categoria Segurança-Desenvolvimento Globalizados que se assemelha à segunda categoria, mas opera na arena de temas globais, como questões ambientais e terrorismo. (Stern e Ojendal, 2010).

No entanto, tal cruzamento não é rígido, é possível o movimento de interconexão entre todas as narrativas o que pode gerar uma infinidade de combinações: "Hence, a nexus can be understood as a network of connections between disparate ideas, processes or objects; alluding to a nexus implies an infinite number of possible linkages and relations." (Stern e Ojendal, 2010, p. 11).

Simon Reid-Henry (2011) responde à proposta de Stern e Ojendal criticando a metodologia dos autores tanto em nível discursivo como prático trazendo a questão central:

The question to be asked, then, is whether there is an alternative way of mapping the development-security nexus that takes Stern and Öjendal's illuminating attention to its discursive construction as a starting point, but that allows us to map not just the 'myriad readings' (Stern and Öjendal, 2010: 10) that result, but also how and why those different readings 'take place' and with what effects. (ReidHenry, 2011, p. 98).

No plano discursivo, portanto, Reid-Henry propõe que não é suficiente encontrar e relacionar os discursos que estão no mesmo espaço epistêmico do nexo. É preciso compreender as construções e relações que informam tais leituras e no plano da prática, quais os seus efeitos. Nesse sentido, o modelo Stern e Ojendal é útil em sua pretensão crítica, mas é necessário que avance.

No que tange ao discurso o nexo deve ser observado não unicamente como o resultado de diferentes abordagens discursivas, mas também como uma parte constitutiva de um conjunto de lógicas mais amplo, assim como propôs Duffield (2010) com o conceito de dispositif: "the security-development nexus can be understood as a dispositif, or 'constellation of insitutions, practices and beliefs that 
create conditions of posibility with a particular field". (Duffield, 2010, p.60). E ainda:

The nexus constitutes a field of development and security actors, aid agencies and professional networks, complete with their own forms of subjectivity, that call forth the conditions of need and insecurity to which collectively, and in competition, they seek to provide solutions. In this process, however, not only is risk normalized, but the origins and causes of the absences and instabilities these actors hope to rectify are also obscured and occluded. (Duffield, 2010, p. 56).

Em um segundo movimento, Reid-Henry propõe compreender o nexo analisando os seus efeitos, e assim conjugar o discurso e a prática: "Attending to the security-development nexus as part of a broader field of discourse and practice is but one basis for a more critical mapping, however." (Reid-Henry, 2011, p.98).

Fazendo referência a Edward Said (1978) e seu trabalho "Orientalismo", Reid-Henry aponta que Said descreve Orientalismo como um campo de discurso e prática que ressoa no uso contemporâneo do nexo segurança-desenvolvimento. Além disso, aponta a contribuição de autores pós-coloniais para a compreensão do nexo enquanto um campo de discurso e prática sem no entanto, reificá-lo ou naturalizá-lo. (Reid-Henry, 2011, p. 99).

Nesse sentido, propõe um modelo metodológico alternativo ao proposto por Stern e Ojendal enxergando três principais lacunas no método do mapeamento de narrativas. A primeira é o direcionamento ao foco regional que se concentra nos países em desenvolvimento. Evidentemente, o nexo desenvolvimento-segurança tem sua referência principal o Sul Global, mas uma visão regional mais abrangente encontraria o nexo em locais como as ex-repúblicas soviéticas, por exemplo. A segunda lacuna se encontra em uma visão focada unicamente em questões relacionadas a desenvolvimento e segurança enquanto que o nexo segurançadesenvolvimento também é encontrado em outros domínios como a economia. E por fim, a visão de que o nexo é uma espécie de alavanca através da qual se estabelece uma relação verticalizada em: “'we' have a control of 'them,". Esse movimento pode ser de fato verificado, mas é vital também observar os impactos do nexo para aqueles que buscam implementá-lo.

Seu argumento central, portanto, é que o projeto de mapear intelectualmente o nexo segurança-desenvolvimento precisa compreender como os quadros analíticos criados pela própria academia contribui para a realidade. Desse modo, 
seu mapeamento alternativo visa responder três questões centrais tendo sempre a referência espacial: Como o nexo ganha forma e significado em e através de imaginários geográficos anteriores? Como o nexo foi promovido e tem resistido em diferentes lugares e configurações (cultural, institucional, legal, política, econômica) e através de diferentes escalas de ação (a casa, a região, a nação)? Como o nexo se constitui dentro dos embates em seu próprio espaço?

$\mathrm{Na}$ mesma direção, David Chandler (2007) propõe que os debates e tentativas de compreensão sobre o nexo entre Segurança e Desenvolvimento têm elaborado críticas no sentido de apontar que o nexo reflete um movimento de solução de problemas (problem-solving) e busca por manutenção do status quo na medida em que os Estados do Norte enxergam a pobreza dos países do Sul como uma ameaça á sua segurança:

On the margins of this 'problem-solving' debate, some critical security theorists suggest that the development and poverty-reduction agenda is already one that has been subordinated to Western security concerns, and that the shift from macrodevelopment approaches to 'good governance', 'pro-poor' policy-making, sustainability and poverty reduction already contains within it the desire to contain these regions of potential instability and signifies the securitization and subordination of the development agenda (Chandler, 2007, p.363.).

Nesse sentido, Chandler aponta que tais abordagens têm separado a retórica política da prática política gerando um movimento que ele conceituou como "antipolítica externa" (anti-foreign policy). Ou seja:

The disconnection between policy rhetoric and political interests is captured by the concept of anti-foreign policy, indicating that policy is no longer framed by an interest-based instrumental relationship between the policy actor and the ostensible object of concern. This lack of framework has resulted in the ad hoc and incoherent proliferation of actors and policy perspectives driving the policy crisis which discussions of the security-development nexus seek to address. (Chandler, 2007, p. 364).

Chandler aponta que em grande medida as críticas ao nexo segurançadesenvolvimento perdem a dimensão da prática ao compreendê-lo sempre à luz da condenação à política externa dos países ocidentais. A proposta apresentada nesta 
dissertação, nesse sentido, é analisar o nexo o compreendendo enquanto discurso e prática sem, no entanto, despolitizar ou esvaziar a crítica, ao contrário, o objetivo é avançar e contribuir para o debate.

Portanto, é no marco teórico do nexo segurança-desenvolvimento que se insere esta dissertação, tendo como preocupação teórica-metodológica conjugar discurso e prática. A proposta aqui apresentada sugere conduzir o debate de modo a compreender como a política externa brasileira operacionaliza na retórica e na prática a interseção entre Segurança e Desenvolvimento a partir de sua relação com a Líbia.

De modo geral, a discussão que permeia o nexo segurança-desenvolvimento traz à tona o debate acerca de padrões de desenvolvimento, mais precisamente acerca da transplantação/imposição de um modelo de desenvolvimento ocidental em situações de conflito e peacebuilding. A seguir, será proposto um esforço teórico de compreensão do nexo estabelecido entre a segurança e o desenvolvimento a partir da perspectiva das potências emergentes.

\section{2}

\section{As potências emergentes e o Nexo - contribuições das potências emergentes para o debate.}

O fim da Guerra Fria marcou um período de transição na governança global inaugurando um processo de transformação no cenário internacional caracterizado por uma tendência à multipolaridade. Esse ambiente mobilizou discussões no campo das Relações Internacionais pertinentes ao papel cada vez mais evidente de estados que apresentaram nesse contexto um rápido desenvolvimento econômico, bem como expandiram sua influência política e cultural. Dessas discussões surge o conceito de "potências emergentes", "rising powers", ou "new powers" (Tank, 2012), entendidas enquanto estados que têm apresentado notável fortalecimento de suas economias ao mesmo tempo em que contestam a atual governança global (Ikenberry e Wright, 2008). Esse debate tem sido profícuo e o conceito de potência emergente tem sido contestado. Apesar das contestações e de suas limitações o conceito ainda é válido contribuindo para a compreensão do atual cenário internacional. 
Nesse sentido, as reivindicações por reforma da governança global por parte das potências emergentes têm lugar nos debates internacionais sobre desenvolvimento e segurança, arenas nas quais têm reivindicado voz e agência. Como acima apresentando, a literatura de Relações Internacionais até então tem discutido o nexo a partir do eixo Norte-Sul. No entanto, alguns recentes esforços de analisar o nexo a partir da perspectiva Sul-Sul podem ser encontrados como os trabalhos de Adriana Abdenur e Danilo Marcondes de Souza-Neto (2014) que analisa o nexo a partir do engajamento do Brasil em Guiné-Bissau e Ian Taylor (2009) cujo pesquisa é direcionada ao papel da China nos países da África subsaariana. Evidentemente, as concepções desses países no que toca ao nexo desenvolvimento-segurança não são necessariamente iguais, mas se aproximam quanto á pretensão de se diferenciarem da visão predominante do Norte se direcionando ao eixo Sul-Sul.

Nesse sentido, é de grande relevância compreender como a interseção entre segurança e desenvolvimento se dá no discurso e práticas a partir da perspectiva das potências emergentes em suas relações e engajamento com outros Estados do Sul Global:

Calls for reform of global governance have prompted new debates about the changing role of rising powers, including the BRICS countries, within the fields of security and development. These debates extend to the question of how these states perceive the links between security and development, and how these perceptions may shape their approaches to contexts of high instability and recurring violence. Understanding rising powers' attitudes towards, and concrete engagement with, the security-development nexus debate is all the more urgent because those states have begun playing a key role (whether through engagement or distancing) in the ongoing discussions of the post-2015 development agenda. (Abdenur e SouzaNeto, 2014, p. 1).

Os autores ainda apontam um posicionamento crítico de alguns países do Sul a respeito de como o nexo é articulado como um legitimador de práticas intervencionistas por parte dos países do Norte, mas também apontam abordagens e perspectivas alternativas de interseção do nexo a partir das potências emergentes:

In Africa, some analysts argue that the security-development nexus representes na attempt by the aid industry to braden its own mandate, and/or as a way of liberal- 
democratic states to legitimize forms of intervetionism (including of the military type) that flaunt the norms of multilateral regimes - a $n$ approach that may ultimately exacerbate inequalitites between North and South (Duffield, 2010). Some of these criticisms have yielded attempts to identify alternative perspectives on the intersection of securitya and development, including approaches unique to certain rising powers, such as the BRICS countries (Neethling e Hudson apud Abdenur e Souza-Neto (2014)

Os debates acerca da cooperação Sul-Sul, nesse sentido, trazem importantes contribuição na medida em que as potências emergentes têm buscado exercer papel chave em questões de segurança e desenvolvimento através da cooperação.

A Cooperação Sul-Sul nos últimos anos tem tido crescente aumento de fluxo desafiando as discussões teóricas tradicionais acerca do Desenvolvimento e Segurança, agora promovidos pela periferia do sistema internacional. As políticas de ajuda foram historicamente concebidas e examinadas a partir da perspectiva ocidental à luz dos binários Ocidente/Oriente, Norte/Sul, países desenvolvidos/países subdesenvolvidos notadamente marcados por relações assimétricas e verticalizadas. O contexto pós Guerra Fria, marcado pela multipolaridade, vislumbra um cenário internacional no qual uma diversidade de atores reivindica maior agência e desafiam o seu status quo.

A ajuda entre Estados que não são considerados doadores tradicionais, ou não "desenvolvidos", tem um percurso histórico como é o caso da cooperação entre o Brasil e a Líbia que data da década de 1970. No entanto, somente nos últimos anos essa cooperação tem sido alvo de interesse e pesquisa. Além do fato de que a ajuda para o desenvolvimento tenha tido o foco voltado para a ajuda fornecida por países "desenvolvidos" aos países "subdesenvolvidos" de fato nos últimos anos a cooperação entre "doadores emergentes" teve exponencial crescimento sendo imbuída de grande caráter de contestação simbólica gerando novos questionamentos acerca de padrões de desenvolvimento e de reordenamento do sistema internacional (Mawdsley, 2012).

Nesse sentido, a cooperação Sul-Sul se pretende horizontalizada, simétrica desafiando as teorias tradicionais das Relações Internacionais e seus esforços explicativos. Consideradas teorias mainstream das RI's as teorias Realista e Neoinstitucional tratam da formação de alianças (Waltz, 1976) ou ainda da cooperação internacional (Keohane, 1984), no entanto, não observam as especificidades dos países não industrializados ou emergentes sendo assim 
limitadas para a compreensão da cooperação Sul-Sul. Por sua vez a Teoria da Dependência compreende o subdesenvolvimento não como uma fase para o desenvolvimento, mas como um fenômeno histórico que reflete o aprofundamento do capitalismo e a dominação/imperialismo dos países do Norte. Como solução propõe trocas econômicas, tecnológicas e técnicas entre os países do Sul. Limita-se por ser mais normativa do que empírica ao propor que as iniciativas dos países do Sul Global seriam sempre neutras. (Amin, 1986).

Por outro lado, a Teoria Social compreende a cooperação Sul-Sul em uma lógica de troca, que deve ser problematizada: em que medida as expectativas dos doadores e recipiendários são atendidas? de fatos tais relações são horizontalizadas como se pretendem?

Em uma abordagem antropológica o trabalho de Emma Mawdsley (Mawdsley, 2012) faz uma contextualização dos movimentos de cooperação internacional levantando questões relacionadas à reciprocidade e doação. É nesse marco teórico da Teoria Social que este trabalho se insere admitindo-se no entanto, a carência teórica e metodológica da definição do termo "Cooperação Sul-Sul" e utilizando-se de recursos dos estudos sociológicos onde a cooperação é compreendida como um processo de troca entre indivíduos e grupos sociais da qual a longo prazo emergem instituições. (Leite, 2010).

Contribui também para este marco teórico a proposta de Elodie Brun (2008) que ao tratar das relações entre países da América Latina e países do Oriente Médio (Brasil, Venezuela, Egito e Irã) como cooperação Sul-Sul elabora a ideia de “espírito do não-alinhamento" fazendo referência ao Movimento dos Países NãoAlinhados do qual o Brasil participou como observador. Nesse sentido, o "espírito do não alinhamento" presente na ideia de Sul Global abarca o desejo de autonomia, ampliação do espaço de ação no cenário internacional e a rejeição da ingerência estrangeira.

Compreendendo, portanto, a cooperação Sul-Sul da maneira mais ampla é possível observar como as potências emergentes cooperam para a promoção do desenvolvimento bem como para a participação na arena das normas de segurança. A reivindicação por um assento permanente no Conselho de Segurança da ONU pelo Brasil e pela Índia, por exemplo, vem acompanhada de esforços nas operações de peacebuilding capitaneadas pela Organização das Nações Unidas. Adriana Abdenur e Danilo Marcondes (2014) apontam como o engajamento do Brasil em 
Guiné-Bissau, por exemplo, contribui para o desejo brasileiro de se afirmar enquanto ator global na arena de segurança e desenvolvimento, nesse caso especificamente em situação de peacebuilding, a partir da cooperação imbuída do discurso do Sul Global. Na seção seguinte será analisado com mais detalhes o posicionamento brasileiro no que tange ao nexo segurança-desenvolvimento.

\title{
2.3
}

\section{O Brasil e o Nexo}

Enquanto potência emergente (Hurrel, 2010), o posicionamento do Brasil acerca do nexo segurança-desenvolvimento está intimamente relacionado aos objetivos de maior atuação no cenário internacional em temas pertinentes aos dois campos evidenciados em suas experiências no Haiti, Timor-Leste e em GuinéBissau:

\begin{abstract}
Although Brazil's experience in post-conflict and fragile states is still limited when compared to its overall South-South cooperation, its role in East Timor, Haiti, and Guinea-Bissau has given Brazilian state and non-state actors a greater voice in global debates relating to peacekeeping, civilian protection, and disaster relief. (Abdenur e Marcondes, 2014, p. 3).
\end{abstract}

A postura brasileira é tradicionalmente reconhecida por um posicionamento crítico ao paradigma liberal de peacebuilding, o que não significa dizer que não existam contradições em seu discurso e prática. É exatamente no seio das discussões sobre peacebuilding que a interseção entre segurança e desenvolvimento se torna evidente e nela é possível analisar as peculiaridades do posicionamento brasileiro:

Peacebuilding, with its close interaction of security and development, or hard and soft power, has become an emerging-power diplomatic niche in which these objectives can be reached.In consequence Brazil has made considerable strides in developing a specific form of peacebuilding that both advances its own interests and brings improvements to the overall practice of peacebuilding in terms of effects on the target population. However, whereas this paradigm is clearly couched in a revisionist stance towards global structures of power and is thus inclined to be critical of the dominant Western-led liberal paradigm of peacebuilding, Brazilian efforts have yet to truly move beyond ad hoc improvements based on domestic experience and towards the development of a true normativa and practical counterproposal. What Brazil considers as the particularities of its incipient model 
are: close contact with the local population; cultural affinities' easing of communication difficulties with local actors; the exportation of successful domestic socioeconomic policies such as combating poverty, hunger and underdevelopment; the use of 'soft power'; and a focus on development aspects of peacebuilding rather than security, using a rhetoric of South- South cooperation and a diplomacy of solidarity as a means to differentiate from the Western liberal paradigm. (Kenkel, p. 284, 2013).

A Responsabilidade de Proteger, princípio evocado pela primeira vez no caso da intervenção da Organização do Tratado do Atlântico Norte (OTAN) na Líbia em 2011 e que deu o desfecho ao conflito decorrente dos desdobramentos da Primavera Árabe nesse país, é um ponto emblemático que evidencia a postura do Brasil no cenário internacional e especialmente sua busca por um papel normativo. Sob o princípio da Responsabilidade de Proteger, Responsability to Protect (R2P), a OTAN intervém na Líbia em 2011 gerando controvérsias.

O conceito de R2P foi elaborado em 2001 através da International Commission on Intervention and State Sovereignty ${ }^{2}$ e foi endossado pela Assembleia Geral da ONU em 2005. Tem como princípio a intervenção com uso da força em casos em que um determinado Estado não exerce sua responsabilidade de proteção de civis violando uma série de direitos humanos contra os seus cidadãos. Essa noção surge no intenso debate que contrapõe a soberania e os direitos dos indivíduos diante do contexto de diversos casos de genocídio, crimes contra a humanidade, crimes de guerra e limpeza étnica perpetrados por Estados ao longo da história recente (Bellamy, 2009). A Responsabilidade de Proteger, substituta do "direito de ingerência" tem três princípios fundamentais: responsabilidade de reagir, responsabilidade de prevenir, responsabilidade de reconstruir. Assumindo tais responsabilidades a ação com uso da força, sob capítulo VII da Carta das Nações Unidas pode ser deflagrada. (Jubilut, 2007).

O Brasil se absteve na votação da Resolução 1973 do Conselho de Segurança da ONU que deflagrou a intervenção da OTAN na Líbia sob o princípio da R2P. Dessa forma, se tornou porta-voz de um novo conceito: Responsabilidade ao Proteger, Responsability while Protecting (RWP), criticando não o princípio da

\footnotetext{
${ }^{2}$ CFR - Council of Foreign Relations - Disponível em: http://www.cfr.org/humanitarianintervention/international-commission-intervention-state-sovereignty-responsibility-protectreport/p24228 Acessado em 16 de outubro de 2013.
} 
R2P, mas sua implementação, apontando a necessidade de esgotar todos os recursos antes do uso da força evitando o agravamento dos conflitos. Nesse sentido, a proposta brasileira do RWP seria complementar o R2P através das seguintes proposições:

\begin{abstract}
All three pillars of the R2P "must follow a strict line of political subordination and chronological sequencing"; All peaceful means have to be exhausted; a "comprehensive and judicious analysis of the possible consequences of military action" must precede the consideration of the use of force; The use of force can only be authorized by the Security Council according to Chapter VII of the Charter, or (and this is noteworthy) "in exceptional circumstances, by the General Assembly, in line with its resolution 377"; The authorization of the use of force must "be limited in its legal, operational and temporal elements", and the enforcement must remain true to "the letter and the spirit" of the explicit mandate; To ensure proper monitoring and assessment of the interpretation and implementation of the Responsibility While Protecting, "enhanced Security Council procedures are needed". The Security Council is also obliged to "ensure the accountability of those to whom authority is granted to resort to force". (Benner, 2013, p.2)
\end{abstract}

Thorsten Benner (2013) aponta ter sido esse um movimento significativo por duas principais razões: primeiro pelo fato da proposta ser de autoria brasileira, sendo o Brasil uma potência emergente de importância chave no atual cenário internacional; e em segundo lugar pelo momento propício de seu lançamento, ter sido após a controvérsia da intervenção na Líbia. Por pressões das potências ocidentais bem como pelo posicionamento da China e Rússia contrário ao RwP pelo endosso à necessidade de intervenção em casos graves, o Brasil ficou isolado e a proposta não foi levada a diante:

Unfortunately, because the West did not show a sufficient degree of foresightedness, in early 2012, Brazil found itself rebuffed by almost all sides. Not only did the West react negatively for the most part. A number of key Western countries were so angered by the initiative that they exerted significant political pressure on the Rouseff government. Both China and Russia were also skeptical since Brazil's RWP contains an endorsement of the need to intervene in grave cases. All the while, fellow rising powers India and South Africa had little to say on the RwP initiative. (Benner, 2013, p. 7).

Não obstante a elaboração do conceito do RwP não tenha sido levada adiante a proposta revela o objetivo brasileiro de se afirmar enquanto ator global e agente normativo no campo da segurança. 
Nesse sentido, Eduarda Hammann e Robert Muggah (2013) afirmam que o questionamento não se limita apenas a "se" a comunidade deve intervir, mas também "como" e por "quem". Essas seriam as motivações da elaboração do RwP pelo Brasil referendando seu compromisso com a não-intervenção e o multilateralismo. Nesse sentido, para os autores os conceitos de R2P e RwP estão intrinsicamente ligados às reflexões do século XXI relacionadas à governança global e à própria natureza do sistema internacional. Cabe ressaltar no entanto, que apesar dos autores apontarem a compromisso brasileiro com a não-intervenção, a proposta da RwP não excluía definitivamente o uso da força, mas sim apontava para a necessidade de se esgotar todos os recursos possíveis antes da ação.

Está posta em questão, portanto, a tensão existente entre a defesa da soberania e ao princípio da não-intervenção, historicamente defendida no discurso da política externa brasileira, e a defesa dos direitos humanos. Ambas expressas na constituição brasileira, sem estabelecimento de qualquer relação de preeminência.

O caso da participação do Brasil na Missão de Paz no Haiti (MINUSTAH) iniciada em 2004 suscitou muitos questionamentos acerca do posicionamento brasileiro e seu apoio à ação sob o uso da força, capítulo VII da Carta das Nações Unidas, embora jamais explicitamente admitido.

A MINUSTAH traz consigo a marca de ser uma missão multidimensional, característica das missões de paz no contexto pós Guerra Fria, onde além do objetivo de estabilização do conflito tem o componente da promoção do desenvolvimento. É nesse contexto que surge o conceito trabalhado pela política externa brasileira denominado "princípio da não-indiferença", uma tentativa de equacionar dois discursos a princípio excludentes: defesa da soberania e defesa dos direitos humanos.

Nesse sentido, é observada a postura política externa brasileira de dar ênfase ao aspecto do desenvolvimento frente ao intervencionismo por uso da força observada na fala do então Ministro das Relações Exteriores do Brasil, Celso Amorim:

O compromisso do Brasil com o Haiti é firme, amplo e de longo prazo. Ao auxiliar o Governo e o povo haitianos a encontrarem o caminho para o desenvolvimento autônomo e sustentável, o Brasil reforça sua opção pela política externa de nãoindiferença, que conjuga solidariedade e pleno respeito à soberania. Em 2004, o Governo brasileiro respondeu prontamente ao chamado das Nações Unidas para integrar os esforços da comunidade internacional para estabilizar o país. Em 
paralelo ao exercício do comando da Missão das Nações Unidas para Estabilização do Haiti (MINUSTAH), o Brasil engajou-se em um abrangente programa de cooperação, em linha com a posição de que as dimensões de segurança, desenvolvimento e consolidação institucional devem ser abordadas de maneira integrada. $^{3}$

É fundamental observar nessa fala a noção de "política externa de nãoindiferença". A concepção de "não-indiferença" visa conjugar a defesa da soberania e a observância e sensibilidade à violação dos direitos humanos.

Possivelmente, um discurso estratégico para manter coerente a defesa da soberania territorial que tradicionalmente marca a política externa brasileira aliada à preocupação com a defesa dos direitos humanos que se figura como uma crescente demanda internacional e que, em grande medida, determina sua margem de ação no sistema.

Os esforços do Brasil no sentido de enfatizar a agenda de desenvolvimento frente à agenda de segurança têm se figurado enquanto posicionamento tradicional da política externa brasileira:

As atividades de longo prazo para consolidação da paz, o investimento nos alicerces e na sustentabilidade da paz faziam parte da posição brasileira tradicional no âmbito das negociações sobre operações de paz e constavam da Agenda para o Desenvolvimento, aprovada pela AGNU em junho de 1997. Resultado de iniciativa de Brasil e Índia para direcionar o foco institucional para questões de desenvolvimento (inclusive no contexto da consolidação da paz pós-conflito) em face da constatação de ênfase excessiva em questões de segurança stricto sensu. (Neves, 2010, p.120)

No âmbito da cooperação podemos encontrar aspectos inovadores que se distanciam em certa medida do modelo da Paz Liberal. Segundo Kenkel:

Os projetos brasileiros, como resultado da mistura de forças e de fraquezas do próprio país, preferem, inerentemente, focar não no lado da segurança da equação, mas no lado do desenvolvimento. De fato, o país tem sido protagonista no fortalecimento da Comissão para Construção da Paz, das Nações Unidas, e, ao mover o mandato da MINUSTAH na direção de um documento mais embasado no desenvolvimento. A negação retórica, se não prática, do uso da força e a ênfase nas raízes econômicas dos conflitos naturalmente distanciam a abordagem brasileira do setor de segurança em que é menos provável que o país atinja maiores ganhos em seus investimentos em recursos de política externa. Nesse sentido, a estratégia brasileira está também menos sujeita à crítica (...) a respeito da superficialidade da paz liberal. (Kenkel, 2013 p.23).

\footnotetext{
${ }^{3}$ AMORIM, Celso In: Brasil-Haiti - Programa de Cooperação Sul-Sul.
} 
Tendo em vista o histórico de cooperação do Brasil com a Líbia, o posicionamento brasileiro sobre o R2P, e as tentativas de apoio na reconstrução pós intervenção no país norte-africano é relevante lançar mão desse arcabouço teórico objetivando compreender como o nexo segurança-desenvolvimento tem sido articulado pelo Brasil em seu engajamento na Líbia.

\section{4}

\section{Conclusão}

O nexo segurança-desenvolvimento pode ser observado desde longa data, mas nunca fora evocado como hoje o é inclusive pelo discurso político, especialmente no contexto de conflitos intra-estatais pós Guerra-Fria e das intervenções em Estados "não ocidentais" após ao 11 de setembro. Entretanto, debates que buscam compreender o nexo entre os dois campos têm foco nas motivações que conduzem a intervenção do Norte em países do Sul especialmente os considerados como "estados frágeis ou falidos" e seus desdobramentos, negligenciando o papel das "potências emergentes" enquanto promotoras de desenvolvimento e segurança. Encontrando essa lacuna teórica este trabalho objetiva contribuir para o debate através da análise de como o nexo se constitui, é operacionalizado e se reflete na prática no eixo Sul-Sul.

O esforço de contribuição teórica deste trabalho propõe uma reflexão acerca da inserção de potências emergentes na promoção de desenvolvimento a outros Estados por meio da cooperação e sobre sua aproximação ou afastamento do próprio discurso acerca da intervenção. Ou seja, o que se propõe é um exame mais atento de tal interseção a partir da perspectiva das potências emergentes, de seus discursos e práticas políticas através do caso do engajamento do Brasil na Líbia.

No campo da segurança o Brasil tem almejado maior margem de ação o que se reflete não somente na histórica reivindicação por um assento permanente no conselho de segurança da ONU, mas também na busca por inserção em debates normativos como é possível observar no caso emblemático do posicionamento brasileiro acerca da intervenção da OTAN na Líbia sob o princípio da 
Responsabilidade de Proteger (R2P) e a proposta de elaboração do princípio da Responsabilidade ao Proteger (RwP).

Também é possível observar a ênfase do discurso brasileiro no campo do desenvolvimento bem como a intensificação da pratica da cooperação para o desenvolvimento que tem crescido exponencialmente nos últimos dez anos, com especial atenção ao continente africano. Portanto, o Brasil almeja se tornar um ator global e opera cada vez mais nessa interseção. Ao dar ênfase à cooperação é possível observar a hesitação da política externa brasileira em securitizar a agenda internacional de desenvolvimento. Nesse sentido, talvez seja possível, no caso brasileiro, inverter a ordem da lógica "nexo segurança-desenvolvimento" para a lógica em "nexo desenvolvimento-segurança" apontando a priorização da agenda de desenvolvimento pela política externa brasileira.

Desse modo, compreendo a relação entre o Brasil e a Líbia a partir da perspectiva do Sul Global, onde Estados em desenvolvimento ou emergentes cooperam e sustentam o discurso de relação horizontalizada e que contesta o status quo do sistema internacional tanto no campo do desenvolvimento quanto no da segurança. Há de se levar em conta as peculiaridades de cada ator observando o desejo evidente expresso na política externa brasileira dos últimos anos de se inserir cada vez mais no sistema, enquanto que o governo Kadaffi na Líbia tendia ao isolamento variando com momentos de abertura.

Foram portanto apresentados os principais marcos teóricos sob os quais esta pesquisa foi orientada. A partir de tais debates podemos analisar como a política externa brasileira mobiliza no discurso e na prática o nexo desenvolvimentosegurança. Nesse sentido, a finalidade central é examinar as aproximações, desvios e contradições entre discurso e prática.

O capítulo seguinte trará um histórico das relações entre o Brasil e a Líbia à luz dos debates sobre Política Externa Brasileira (PEB) e em seguida será feito um movimento de análise do engajamento do Brasil na Líbia a partir da perspectiva do nexo Desenvolvimento-Segurança. Como o Brasil articula sua margem de ação na agenda de desenvolvimento e segurança no cenário internacional? Quais são os interesses econômicos do Brasil na Líbia despolitizados pelo discurso humanitário da RwP? Como o Brasil mobiliza seu interesse em exercer papel normativo? Essas são as questões que tentarei responder nos capítulos seguintes e que sempre se remeterão à questão central deste trabalho: Em que medida a cooperação para o 
desenvolvimento oferecida à Líbia pelo Brasil corresponde ao discurso oficial da diplomacia brasileira no que diz respeito às intervenções humanitárias? 


\section{3}

\section{As Relações Brasil e Líbia em perspectiva histórica}

O recorte temporal desta dissertação delimita-se pelas relações entre o Brasil e a Líbia correspondente aos governos de Lula e Dilma. No entanto, se no governo Lula há substancial incremento da cooperação entre os dois países é importante destacar que em perspectiva histórica tais relações têm uma trajetória maior e que não deve ser negligenciada. Nesse sentido, neste capítulo será feito um panorama de tal contexto histórico juntamente à análise das transformações da política externa brasileira ao longo desse período bem como do contexto internacional fortemente marcado pelos desdobramentos da Guerra Fria e do Pós Guerra Fria.

Em 1913 foi estabelecido o primeiro consulado brasileiro em Trípoli com jurisdição em Tripolitânia e Cirenaica, quando ainda o território estava sob ocupação italiana. Sem nenhum movimento posterior de aproximação significativo, somente em 1967, já após a independência líbia, a embaixada brasileira em Túnis respondia pelos os interesses brasileiros na Líbia. (Devido à instabilidade política, em 2014 a embaixada brasileira da Líbia é transferida novamente para Túnis ${ }^{4}$. No entanto, é na década de 1970, durante a ditadura civil-militar no Brasil e já no governo Kadaffi, que as relações entre Brasil e Líbia se estreitam de forma significativa. Esse estreitamento foi impulsionado fundamentalmente pelos efeitos da crise energética mundial.

Durante esse período é observado com destaque o governo do presidente militar brasileiro Ernesto Geisel (1974-1979) no qual, diante dos desdobramentos da crise do petróleo de 1973, a política externa brasileira se volta fortemente para os países árabes produtores de petróleo incluindo a Líbia. Tal análise não

\footnotetext{
${ }^{4}$ EBC Agência Brasil Disponível em: http://agenciabrasil.ebc.com.br/internacional/noticia/201407/itamaraty-transfere-embaixada-da-libia-para-tunisia-por-falta-de Acessado em: 07de janeiro de 2015
} 
desconsidera, no entanto, um preâmbulo dessas relações ainda no governo anterior, ou seja, durante a gestão de Emílio Garrastazu Médici (1969-1974). Esta análise contemplará ainda o arrefecimento das relações entre os dois países durante o período de redemocratização no Brasil, compreendendo portanto as relações Brasil e Líbia desde o governo Médici até o governo de Fernando Henrique Cardoso (1995-2003). Os governos Lula e Dilma, quando tais relações tomam proporções jamais vistas anteriormente, serão analisados no capítulo seguinte.

Este capítulo divide-se em duas seções: a primeira sob o título "Líbia Independente (1951-2011)" traça um breve histórico do processo de independência da Líbia e seus desdobramentos culminando na instituição da Jamairia (República) Árabe Popular Socialista da Líbia sob a liderança de Muammar al-Kadaffi. A segunda seção "Relações Brasil e Líbia entre 1969 e 2002: um panorama” traça um histórico das relações entre os dois países estabelecendo o marco temporal a partir das primeiros acordos e trocas comerciais significativas até o governo de Fernando Henrique Cardoso, imediatamente anterior ao governo de Lula. Por fim, será apresentada uma breve conclusão.

\title{
3.1
}

\section{Líbia Independente (1951 -2011)}

\begin{abstract}
Land is no one's property, but everyone has the right to use it, to benefit from it by working, farming, or pasturing. This would take place throughout a man's life and the lives of his heirs, and would be through his own effort without using other, with or without wages, and only to the extent of satisfying his own needs. (...) The purpose of the new socialism society is to create a society which is happy because it is free. This can be achieved through satisfying the material and spiritual needs of man, and that, in turn, comes about through the liberations of these needs form outside domination and control.
\end{abstract}

Muammar al-Kadaffi, 1975.5

O território hoje correspondente à Líbia esteve sob o Império Otomano de forma descontínua durante séculos até ser disputado pela recém unificada Itália no

\footnotetext{
${ }^{5}$ CHRISTMAN, Henry. Qaddafi's Green Book. Prometheus Books. New York. 1988
} 
início do século XX. Tal processo de ocupação e colonização italiana não ocorreu sem resistência:

In all African societies the people instinctively rose up to oppose foreign occupation, and Libya was no exception. Libyan peoples of differing ethnic groups united to oppose Italian occupation and a consciousness about being Libyan emerged in this anti-colonial period between 1911 and 1941. There was constant guerrilla resistance against the Italians, especially after the Benito Mussolini forces acceded power in 1922 and imposed fascist administrative structures in Libya. In order to snuff out rebellion, the fascists imported large numbers of Italian settlers and developed infrastructure to coordinate colonial control. Peoples from all regions rebelled against colonial fascism (...) (Campbell, 2014, p. 14).

Com a II Guerra Mundial o território foi dividido entre a França e a GrãBretanha correspondendo à primeira a região de Fazzan e à segunda as regiões de Tripolitânia e Cirenaica. Em 1945 o território Líbio foi colocado sob tutela da então criada Organização das Nações Unidas. Ao fim da década de 1940 as províncias de Tripolitânia, Cirenaica e Fazzan se organizam e criam o Reino Unido da Líbia em dezembro de 1951. No dia primeiro de janeiro do ano seguinte a ONU reconhece a independência da Líbia que se constitui sob uma monarquia liderada pelo rei Idris I pertencente ao grupo islâmico Sanussi e nativo da região de Cirenaica e em 1953 a Líbia integra a Liga Árabe.

Segundo a autora Lisa Anderson (1986) em um trabalho de perspectiva comparada dos processos de independência da Líbia e da Tunísia, o processo Líbio se deu sem aparato de estado e burocracia estáveis:

Unlike tunisia, Libya came to independence without a stable apparatus. The succeding quarter century demonstrated both the social structural consequences of the absence of a stable state bureaucracy and the influence of substantial external revenues in postponing the development of such an administration. In stark contrast to the Tunissian experiene, Libya's history of independence witnessed little stable political activity on the basis of class or clientelism, despite the country`s high level of integration into the world capitalist economy, and exhibited a consistent avoidance of bureaucratic state structures (Anderson, 1986, p. 251).

Anderson ainda compara o caso da formação de um Estado burocrático na Tunísia e na Líbia com os padrões de formação do Estado nos países industrializados europeus. Nesse sentido, inclui o movimento de formação do Estado nesses dois países no processo comum que ao processo dos países que compõem o “Terceiro Mundo". A diferença está no fato de que na Europa o Estado 
é fruto das lutas sociais enquanto que na Tunísia e na Líbia o Estado é anterior ás lutas, devido ao histórico de colonialismo da região. Ambos os países têm características que resultam de sua formação enquanto Estados Modernos e o desenvolvimento burocrático. No entanto, a questão do petróleo é emblemática na Líbia e é um fator de diferenciação em relação a política desenvolvida na Tunísia.

A autora ainda relaciona a questão da burocracia associada a uma política econômica distributiva; as disputas com as elites rurais; o sistema de políticas de patronagem comum na região e o cenário internacional do capitalismo; e o concomitante movimento da periferia do sistema internacional.

In Libya, the precolonial administration was destroyed, and with it, the networks of cliente that had grown up around it. The resilience of broad-based political organization based on clienteles is demonstrated by the strength and breadth of the Libyan resistance to the Italians. As is suggested in part IV, however, the absence of the stable administration that has sustained the patrons of the networks eventually led to the demise of the networks themselves and to the revival of relance on kinship as the primary organizational principal in the hinterlands (Anderson, 1986, p. 10).

Isso se deve ao fato de que embora tenham se tornado independente através de uma monarquia as três regiões, Fezzan, Cirenaica e Tripolitânia, se uniram em uma espécie de federação na qual não existiam estruturas de um Estado Moderno aos moldes weberiano. No entanto, em 1959 são descobertas reservas de petróleo, o que trouxe grandes transformações de ordem político-econômica.

Quando da independência, no final de 1951, cerca de $80 \%$ da população na Líbia trabalhava em atividades rurais. A economia formal nos primeiros anos de independência era baseada na exportação de sementes de mamona, grama esparto (planta típica da região do norte da África utilizada em artesanato), e sucatas de metal de veículos militares da II Guerra Mundial, contando ainda com ajuda bilateral e multilateral ( St John, 2013, p. 85) O uso indiscriminado de minas terrestres durante a II Guerra Mundial trouxe grandes danos ao desenvolvimento econômico pela poluição do ar, das águas, pela prospecção de cerca de 12 milhões de minas terrestre em toda a região do Norte da África, além de limitados recursos humanos por um índice pequeno de crescimento da população. (Ibid. p. 86).

Em 1914 traços de petróleo foram encontrados na região, mas somente em 1959 que reservas em quantidades comerciais viáveis foram descobertas. A Bacia 
de Sirte, onde se localizava a maior parte dos campos de petróleo iniciais, continha grandes depósitos de petróleo de alto grau de "sweet crude" que um é o óleo que tem baixo teor de enxofre, portanto uma qualidade desejável em um mundo cada vez mais ambientalmente consciente, e além disso, tem o custo de refino reduzido. Localizado mais perto da Europa do que os seus concorrentes, a Líbia também se beneficiou de uma vantagem em termos de custos de transporte, e foi menos vulnerável a interrupções no fornecimento, uma vez que não dependia de gasodutos, como o Canal de Suez, ou de trânsito no nordeste da África para atingir os seus mercados. (Ibid.).

A descoberta do petróleo alterou fortemente a economia que até então era predominantemente agrária e voltada para a exportação de ferro, trazendo grande aumento da renda per capita transformando a Líbia em um dos países com maior Índice de Desenvolvimento Humano da África. Tal descoberta também alterou sua composição política. Em 1963 a Líbia se torna de fato unificada, ocorre a mudança do nome de Reino Unido da Líbia para Reino da Líbia e é gestada uma estrutura de Estado mais próxima aos moldes modernos, com exceção do exército e o uso da força que ainda não eram monopólio do Estado. Também se constituí nesse momento um Estado de economia distributiva, onde o preço do petróleo é o que determina a renda e não as variações das taxas e impostos coletados pelo Estado (Vandewalle, 1998).

Significantly, however, it also allowed the state to take a passive role in regulating economic behavior. Institutionally, the state had not been strengthened. For most of Libyans, it lacked intrusiveness but also held few attractions beyond its role as purveyor of increasingly handsome economic rewards. Economically, after a decade of virtual nonregulation at the national level, the rapid inflow of oil revenues had forced the government to intervene, but it used that intervention to strengthen its distributive capabilities - an easy task in light of the continued oil revenue inflows - at the expense of extraction and active regulation. (Vandewalle, 1998, p. 55).

Ficou conhecida como Oil Policy a prática em que as empresas estrangeiras que exploravam o petróleo pagavam à monarquia um valor em impostos fixados a partir dos preços dos barris. Os preços, portanto, orientaram a taxação de acordo com o volume de petróleo extraído. Entre 1961 e 1969 as receitas derivadas da exportação do petróleo subiram de \$3 milhões de dólares para $\$ 1.175$ bilhões e a Líbia se tornou o quarto maior país exportador de petróleo do mundo, deixando de 
ser um Estado deficitário, para se tornar um Estado com excedentes de capital. Em 1969 a produção diária da Líbia comparava-se a da Arábia Saudita. (St John, 2013, p. 87).

Em 1969 um movimento nacionalista liderado por Muammar al-Kadaffi derruba a monarquia instituindo a Jamairia (República) Árabe Popular Socialista da Líbia. Tal movimento teve forte influência das ideias socialistas e do pan-arabismo. A partir de então, as forças militares estrangeiras (bases americanas e britânicas) presentes na Líbia foram expulsas e iniciou-se o processo de nacionalização das empresas, bancos e do petróleo. (Vandewalle, 1995).

Segundo Dirk Vandewalle (1995) a independência da Líbia insere-se em um contexto de duplo desafio: a formação do estado pós- independência e o crescimento econômico que se seguiu à descoberta do petróleo.

\begin{abstract}
It is correct then to argue, as several observers have, that Kadaffi and his revolution are the result both of a particular history and of the vat financial resources out at his disposal by an accident of nature. Furthermore, a critical element in understanding the persistence of the regime is the presence of those rapid capital inflows, in particular the power they afforded the Libyan government to pursue its idiosyncratic social and political development without much fear of political or economic repercussions. The Jamahiriyya as a rentier state, has never know the constraints faced by most modern nations in which those in powr provide some representation, even if symbolic or minimal, in return for some taxation. (Vanderwalle, 1995, p. 4).
\end{abstract}

Para Lisa Anderson (1995), a política econômica de Kadaffi caracterizou-se por ser orientar nas bases de uma economia distributiva bem sucedida nos primeiros anos, mas decadente com o crescente aumento da população e com uma indústria e agricultura limitadas. Desse modo, as identidades em uma sociedade de economia distributivas não têm base econômica sendo portanto as identidades tribais as principais arenas de disputa política. A autora ainda aponta ter sido a experiência da Jamairia sob o governo Kadaffi de fato um desafio em níveis globais:

(...) the Libyan political experiment was exceptionally ambitious. It was intended to strengthen and diversify the country's economy, redistributive national resources, encourage new social and political affiliations, foster reform in the Arab world and induce revolutionary change in global politics. While very little of this agenda was accomplished, the efforts themselves had profound consequences for the country and its people". (Anderson, 1995, p.225) 
Quatro anos depois da Revolução de 1969 o Conselho de Comando Revolucionário nacionalizou $51 \%$ de todas produtoras de petróleo estrangeiras. Foi registrado um considerável aumento de preço com o boicote da OPEP em abril de 1974, configurando o denominado Choque do Petróleo (St John, p. 87, 2013). No entanto, ao longo da década de 1980 houve uma redução gradual do preço que juntamente com o embargo dos EUA à compra do petróleo trouxe grande crise econômica à Líbia. (Ibid. p. 88).

Ao longo da década de 1980, a liderança da Líbia se deparou com grandes desafios em sua política externa. Em 1980 rompe relações diplomáticas com a Arábia Saudita depois de controvérsias acerca de políticas relacionadas à comercialização do petróleo. Também nesse mesmo ano há a intervenção da Líbia no Chade o que suscita além do isolamento regional, a oposição do governo francês. (Vandewalle, 1998).

As relações com o "ocidente" se agravam após os bombardeios norteamericanos na Líbia em 1986, (em represália a suposto ataque terrorista líbio a uma discoteca em Berlim onde estavam soldados norte-americanos), e a queda da URSS, um de seus principais aliados.

Tal isolamento reflete-se na economia do país já debilitada pelo embargo imposto pelos EUA em 1982 e pela queda do preço do petróleo. Embora uma das características emblemáticas do governo Kadaffi seja o anti-imperialismo, esse período de transição entre as décadas de 1980 e 1990 impôs a necessidade de posições mais moderadas, como o posicionamento moderado líbio a respeito da anexação do Kuwait e a invasão do Iraque durante a Guerra do Golfo o que também se observou nas negociações em 1992 acerca do julgamento dos suspeitos de atacar o avião da Pan Am em dezembro de 1988, conhecido como o caso de Lockerbie. Kadaffi propõe cooperar nas investigações do caso que envolvia supostos terroristas líbios. Tais eventos marcam uma flexibilidade ideológica que não se observava na década de 1970 (Anderson, 1995) que também foi acompanhada por esforços de reforma e abertura econômica:

In March 1987, Qadhafi annouced the first in a series of economic and political measures (infitah), intended to return Libya to a more open, free-enterprise system. Describing the new policies as a "revolution within the revolution", he envisioned a new role for the private sector, together with limited political liberalization. Later, he called for reforms in the agricultural and the industrial sectors, including a reversal of import substitution policies and the adoption of modern management 
practices. In September 1988, Qadhafi called for an end to the state monopoly on trade and lifted some injunctions on retail trade with the result that suqs and small urban shops began to reopen. (St John, 2013, p. 90).

Apesar de contínuo processo de abertura política e econômica o poder ainda centralizado de Kadaffi não prossegue sem resistência. Lisa Anderson aponta que a maior oposição ao regime de Kadaffi aos meados dos anos 1990 é interna: oposição islâmica, posição pro-ocidente e a própria incapacidade do regime de se auto-reformar. (Anderson, 1995).

No final da década de 1990 e início dos anos 2000 o petróleo continua a corresponder a $95 \%$ das exportações e de $70 \%$ a $80 \%$ das receitas do governo. Em 2003 todas as sanções contra a Líbia foram revogadas e em junho do mesmo ano Kadaffi anunciou uma grande mudança da política econômica de seu governo dizendo ao Congresso Geral do Povo (CGP) que o setor público havia falido e que devia ser abolido. Assim, propôs a privatização da indústria de hidrocarbono juntamente com outros setores da economia e a entrada da Líbia na Organização Mundial do Comércio (OMC). Quatro meses depois o estado norte-africano anunciou uma lista de 360 empresas estatais destinadas a privatização ou liquidação. Juntamente com essa proposta de reforma econômica Shukri Ghanem foi nomeado como primeiro-ministro. Ghanem, foi anteriormente o ministro da economia e comércio exterior além de chefe de pesquisa na OPEP, caracterizavase por ser um forte defensor das privatizações. Em dezembro de 2004 Ghanem traçou uma nova estratégia de desenvolvimento centrada na diversificação econômica. (St John, 2012, p. 91). Tal abertura econômica gerou importantes impactos e críticas internas:

Public criticism of liberalization policies intesified in mid-2005 when the government imposed a 30 percent hike in fuel prices and doubled the price of electricity fot consumers of more than 500 kilowatts a month. A related decision to lift customs duties on more than 3.500 imported commodities raised concerns for job security in inefficient factories. (Ibid.)

Kadaffi permanece no poder até sua morte no ano de 2011, completando 42 anos de governo, durante a intervenção militar da OTAN no contexto dos movimentos políticos e sociais travados em vários países árabes, dentre eles a Líbia, que ficou conhecido como Primavera Árabe e que será analisado com maior destaque no terceiro capítulo. 
Esta seção iniciou-se com uma epígrafe retirada do "Livro Verde" de Muammar al-Kadaffi. Nesse trecho é claramente explicitada a orientação socialista do governo Kadaffi e a ideia de compartilhar de forma igualitária a terra e seus recursos. No entanto, cabe ressaltar a peculiaridade do socialismo de Kadafi caracterizado como um socialismo islâmico fortemente influenciado pelos movimentos nacionalistas árabes. Tal concepção fundamentou ideologicamente o processo de nacionalização de várias empresas líbias, e com destaque, as empresas de petróleo. É justamente o ouro negro o protagonista do estreitamento dos laços entre Brasil e Líbia que será examinado na seção seguinte.

\section{2}

\section{Relações Brasil e Líbia entre 1969 e 2002: um panorama}

Após uma breve contextualização dos processos políticos e econômicos da Líbia desde sua independências aos últimos anos do governo Kadaffi, nesta seção serão contemplados os movimentos de aproximação, continuidades e descontinuidades das relações entre o Brasil e a Líbia anteriores ao governo do Partido dos Trabalhadores no Brasil observados à luz das transformações da política externa brasileira bem como do contexto internacional instaurados no bojo dos períodos da Guerra Fria e do Pós Guerra Fria.

Entre as décadas de 1960 e 1970 o cenário internacional foi marcado por mudanças fundamentais que reverberaram sobre o alinhamento da política externa brasileira ao bloco norte-americano em pleno contexto de Guerra Fria. Dentre tais mudanças há de se creditar importante destaque para o processo de descolonização da África e da Ásia que alteram o centro de gravidade do sistema internacional deslocando o eixo Leste-Oeste para Norte-Sul. (Gonçalves e Miyamoto, 1993).

É nesse momento que surge a noção de "Terceiro Mundo" fortemente marcada pela lógica do desenvolvimentismo a ser perseguido pelos estados recém independentes bem como pelos estados da América Latina que assumem a posição de "países em desenvolvimento." Além disso, a Crise do Petróleo no início da década de 1970 foi fator fundamental para os significativos movimentos de aproximação entre o Brasil e os países árabes produtores de petróleo. Precisamente nesse contexto de aproximação dos países do "Terceiro Mundo" e de crise 
energética mundial que o Brasil e a Líbia dão os primeiros passos significativos de cooperação.

Um dos elementos de continuidade da política externa brasileira é o firme objetivo do desenvolvimento, o que impulsiona a busca de novos mercados e novas fontes de matéria-prima e energia. O desenvolvimentismo foi a marca dos governos militares no Brasil, o que ocorreu, no entanto, ao custo de grande inflação e aumento da dívida externa. A crise do petróleo em 1973 impulsionou a orientação da política externa brasileira para os países produtores de petróleo a fim de prover energia capaz de movimentar seu parque industrial.

Em 1969, durante a ditadura civil-militar no Brasil, assume a presidência da República o general Emílio Garrastazu Médici cujo governo se estende até 1973. A Política Externa Brasileira durante seu governo foi caracterizada pela "Diplomacia do Interesse Nacional” (Gonçalves e Miyamoto,1993), (Vizentini, 2004), na qual se manteve o foco na busca pelo desenvolvimento, tal qual as gestões anteriores, mas agora este seria alcançado através de relações bilaterais:

Pode-se afirmar que o principal efeito desses condicionantes sobre a política externa foi que, à convicção da diplomacia de que o desenvolvimento era o resultado exclusivo da interação dos fatores internos, acrescentou-se a ideia de que o caminho do desenvolvimento era para ser percorrido individualmente. Se, antes, a "diplomacia da prosperidade" divisava a luta conjunta dos países subdesenvolvidos como o meio mais eficaz de resistir e superar os obstáculos que lhes opunham os desenvolvidos, a "diplomacia do interesse nacional" passou a priorizar as relações bilaterais como as mais convenientes para se alcançar o mesmo fim." (Gonçalves e Miyamoto, 1993, p. 25).

O então ministro das Relações Exteriores Mário Gibson Barbosa definiu da seguinte forma as linhas da diplomacia do interesse nacional:

o Brasil defende a mudança das regras de convivência internacional, é contra a cristalização de posições de poder e se recusa a crer que a história se desenrole necessariamente em benefício de uns e prejuízo de outros países; consideramos que, à medida que um país cresce, cabe-lhe uma parcela de decisão cada vez maior dentro da comunidade internacional, e não devemos deixar de usá-la em favor dos povos que, como o nosso, aspiram ao progresso; a verdadeira paz não pode ser identificada como a simples manutenção do status quo, como resultado do equilíbrio de poder, nem ser instrumento de ampliação da distância que separa as nações ricas das nações pobres; implica, ao contrário, a mudança das regras do comércio internacional e a alteração do mecanismo de distribuição mundial do progresso científico e tecnológico, pois não há verdadeira paz sem desenvolvimento; nossa posição é, portanto, de ativa solidariedade com os países em desenvolvimento, competindo à nossa diplomacia estreitar o entendimento com 
os povos que travam conosco a dura batalha do progresso; nossa política externa deve ser global, de íntima cooperação com os países desenvolvidos. (Gonçalves e Miyamoto, 1993, p. 15).

Nesse ensejo foi assinado o acordo entre a Braspetro (subsidiária da Petrobras responsável pelas relações internacionais da estatal brasileira) e o governo Líbio. A Líbia passa então a ocupar um papel de destaque no comércio exterior brasileiro No primeiro semestre de 1970 foi criada a primeira Comissão Mista Brasil-Líbia:

O governo Líbio, por intermédio do seu Ministro do Desenvolvimento Agrícola, Abdul Mejid Ga'ud, buscava estabelecer parcerias com o governo brasileiro na área da construção pesada. A compra de outros equipamentos brasileiros estava vinculada ao fornecimento de petróleo líbio. O governo do país árabe necessitava de remessas de maquinário e alimentos brasileiros. A administração líbia previa a construção de novas três cidades e, para isso, contava com o apoio brasileiro. A visita de Abdessalam Jailoud seria o marco para o estabelecimento da parceria, Segundo a publicação da Liga dos Estados Árabes, ele era considerado o "braço direito" de Kadaffi. A Vale do Rio Doce, entre outras empresas brasileiras foi contratada pelo governo líbio. Outros setores poderiam ser privilegiados pelo mercado líbio, entre eles o automobilísitico. (Preiss, 2013. p.72).

Em 1973 com os desdobramentos da Guerra do Yom Kippur os países pertencentes a Organização dos Países Exportadores de Petróleo (OPEP), que inclui a Líbia, aumentaram drasticamente o valor do barril para exportação comprometendo o abastecimento dos países importadores deflagrando o Primeiro Choque do Petróleo. A economia brasileira foi fortemente afetada pois $80 \%^{6}$ do petróleo consumido era importado, entre 1973 e 1974 os gastos com importação de petróleo subiram $299 \%^{7}$ o que levou à aproximação do governo brasileiro aos países árabes e, portanto, para prosseguir o plano desenvolvimentista o governo brasileiro diversificou e ampliou suas relações com a região do Oriente Médio e do Norte da África. Nesse sentindo, abandona a diplomacia da equidistância no que concerne aos conflitos Árabes-Israelenses se posicionando favoravelmente à causa Palestina

\footnotetext{
${ }^{6}$ SCHNEIDER, Ronald M. Amongst Brazil's most important suppliers were Saudi Arabia, Iraq, Algeria, Kuwait and Iran, all OPEC members. "Brazil - Foreign Policy of a Future World Power". Op. cit., p. 24. apud PINHEIRO, Letícia. Foreign Policy Decision-Making under Geisel Government. FUNAG, Brasília. 2013. p. 117.

${ }^{7}$ VELLOSO, João Paulo dos R. O último trem para Paris, Rio de Janeiro, Ed. Nova Fronteira, 1986, p. 220. apud PINHEIRO, Letícia. Foreign Policy Decision-Making under Geisel Government. FUNAG, Brasília. 2013. p. 117.
} 
e aos países da Liga Árabe ampliando seu mercado de exportação e principalmente garantindo o fornecimento de petróleo:

\begin{abstract}
A intensificação da aproximação com o Oriente Médio, a qual preencheu certos vazios diplomáticos da atuação brasileira, está associada à crise energética da primeira metade da década de 1970 e ao projeto nacional de desenvolvimento econômico. Diante da alta do preço do petróleo, equilibrar a balança comercial com os países daquela região e garantir o fornecimento de óleo em contexto internacional de instabilidade política consistiam questões cruciais para o país. Com efeito, durante o período em tela, o Brasil logrou diversificar sua agenda bilateral - estabelecendo relações diplomáticas com cerca de dez Estados da região -, haja vista a esperança de atrair novos mercados para as exportações nacionais. (Santana, 2006. p. 1).
\end{abstract}

No ano seguinte assume o governo brasileiro o presidente militar Ernesto Geisel cuja política externa, com importante presença do chanceler Azeredo da Silveira, foi definida como "Pragmatismo Responsável” (Vizentini, 2004) ou ainda "Pragmatismo Ecumênico Responsável” (Spektor, 2004). Esse período é definido por crescente aumento do grau de autonomia e independência da PEB no cenário internacional.

O alinhamento automático aos interesses norte-americanos é substituído pelo pragmatismo com maior margem de manobra e ação. Essa mudança é resultado das transformações do contexto internacional em curso entre as décadas de 1960 e 1970, tais como: o processo de descolonização da África e da Ásia, o declínio relativo do poderio militar norte-americano frente à União Soviética, a Guerra do Vietnã e seus desdobramentos, a inserção da China como ator na nova configuração global de poder, a ascensão da Europa e do Japão como centros de poder econômico e especialmente a crescente força dos países produtores de petróleo através da OPEP. (Spektor, p. 195, 2004). Como observado no início desta seção, esse processo de reconfiguração desloca o centro de gravidade do sistema internacional do eixo Leste-Leste para o eixo Norte-Sul. (Gonçalves e Miyamoto, 1993).

Diante da Assembleia Geral da ONU o então chanceler brasileiro Azeredo da Silveira apresenta as diretrizes da PEB:

Queremos que a nossa linguagem, no plano internacional, seja direta e simples, sem ambiguidades e subterfúgios. Queremos que o Governo brasileiro possa cumprir a vocação ecumênica de seu povo, aberto à comunicação desinibida e franca. Queremos explorar todas as vias do entendimento, por acreditarmos, 
fundamentalmente, que a cooperação é mais eficaz do que o antagonismo e que o respeito mútuo é mais criador do que as ambições de preponderância Nossa conduta, para alcançar esses objetivos, é pragmática e responsável. Pragmática, na medida em que buscamos a eficácia e estamos dispostos a procurar, onde quer que nos movam os interessas nacionais brasileiros, as áreas de convergência e as faixas de coincidência com os interesses nacionais de outros povos. Responsável, porque agiremos sempre na moldura do ético e exclusivamente em função de objetivos claramente identifica dos e aceitos pelo povo brasileiro." (Gonçalves e Miyamoto, 1993, p. 20).

Segundo Matias Spektor tal pragmatismo distinguiu-se pela aproximação da política externa brasileira ao projeto normativo das tradições realistas da política internacional, porém, aos valores realistas foram somados elementos típicos da política externa brasileira tradicional e assim a condução da política externa pelo governo Geisel e "a integração entre essas duas vertentes enfrentou problemas e deixou muitas perguntas sem respostas”. (Spektor, 2004, p. 195). Sendo portanto sua análise um desafio teórico.

A questão energética continua sendo um elemento definidor na condução das relações exteriores durante o governo Geisel:

Os efeitos dessas mudanças internacionais, sobretudo o choque do petróleo, atingiram pontos vitais dos interesses nacionais brasileiros, forçando o governo a uma profunda revisão de sua estratégia político-diplomática. Ao tornar ostensiva nossa debilidade na área energética produzíamos apenas $28 \%$ do petróleo utilizado - e nossa impossibilidade de acesso às engrenagens dos centros decisórios do sistema financeiro internacional - que elevou os juros da dívida externa -, a crise fez com que os estrategistas percebessem não só que ainda era grande a distância que separava o Brasil dos países ricos, como também que a insistência no bilateralismo diplomático conduziria a um inevitável isolamento internacional. Urgia, portanto, substituir o individualismo típico do período Médici por uma aproximação com o Terceiro Mundo. (Gonçalves e Miyamoto, 1993, p. 20).

Letícia Pinheiro (2013) aponta que além do redirecionamento a novos mercados imposto pela crise do petróleo, o alívio das relações entre Moscou e Washington resultaram em um ambiente favorável para que os países periféricos como o Brasil conduzissem sua política externa de forma mais independente e nacionalista ampliando suas relações bilaterais e multilaterais. Embora um movimento de reorientação para a Europa Ocidental, Japão, países Socialistas e do Terceiro Mundo tenha sido observado na condução da política externa brasileira desde o final da década de 1960 é somente no governo Geisel que uma reorientação decisiva foi de fato implementada. 
Os interesses da diplomacia brasileira, portanto, se estenderam para além do continente americano em busca de novos mercados para a produção nacional e de fornecedores de matérias-primas e tecnologia, insumos que fomentariam o parque industrial brasileiro. É nesse período que a embaixada brasileira na Líbia foi instalada bem como as embaixadas brasileiras no Iraque, Kuwait e Arábia Saudita, países extremamente relevantes para as relações exteriores brasileiras devido à grande importação de petróleo em troca de produtos tais como açúcar, café e manufaturas em geral (Gonçalves e Myiamoto, 1993).

A embaixada brasileira na Líbia foi instalada em 1974 e em 1978 foi assinado um acordo básico de cooperação que previa: promoção das relações econômicas e de comércio entre os dois países; cooperação nas áreas cultural, científica e técnica, esporte e saúde; cooperação na área do petróleo e em outras atividades energéticas; promoção de intercâmbio cultural entre ambos os países ${ }^{8}$. A fotografia a seguir retrata a visita do então ministro do Petróleo da Líbia ao Brasil em 21 de junho de 1974 recebido pelo presidente Ernesto Geisel.

\footnotetext{
${ }^{8}$ MRE -Ministério das Relações Exteriores - Sistema Atos Internacionais. Disponível em: http://daimre.serpro.gov.br/atos-internacionais/bilaterais/1978/b 48/ Acessado em: 23 de outubro de 2014.
} 
Figura 1 - Ernesto Geisel, Shigeaki Ueki, Araken de Oliveira e outros por ocasião da visita do ministro do petróleo da Líbia

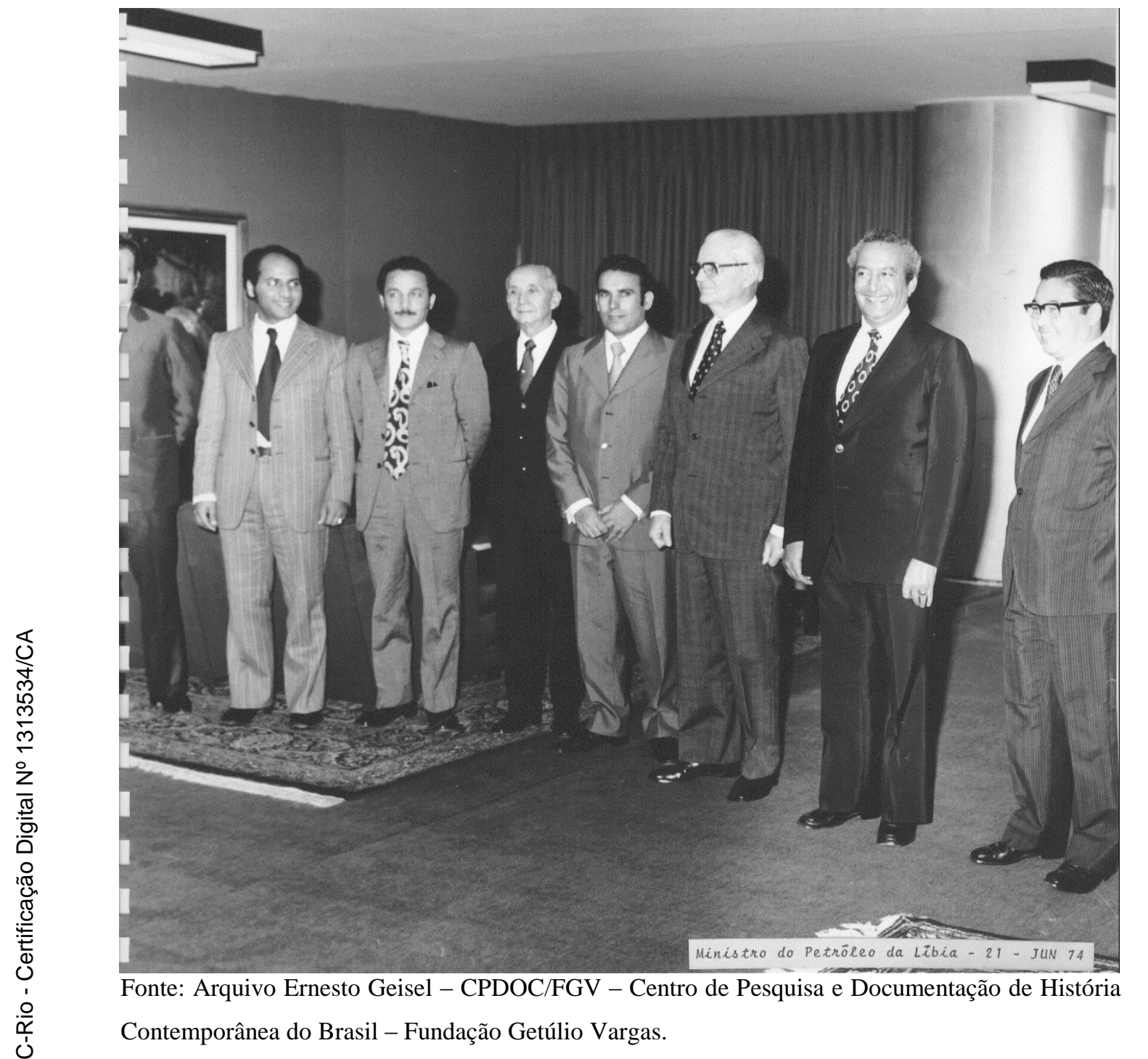

Em resposta à Crise do Petróleo, Geisel lança o Segundo Programa Nacional do Desenvolvimento, II PND, objetivando estimular a produção interna de alimentos, matéria-prima e principalmente energia. No ano seguinte, em 1975 um tema polêmico referente ao petróleo dividiu opiniões. Diante da instabilidade política na região do Oriente Médio e Norte da África, do aumento do preço do petróleo e decorrente crise econômica, Ernesto Geisel, também presidente da Petrobras, autoriza a assinatura dos "contratos de risco" (termo técnico que define o tipo de contrato em que o contratado presta algum serviço ou investe em determinado projeto recebendo como remuneração apenas a participação dos lucros 
assumindo assim os riscos da empreitada ${ }^{9}{ }^{10}$ ) que sinalizaram a abertura para empresas privadas explorarem petróleo no Brasil.

A coluna do dia 27 de setembro de 1975 do Jornal do Brasil intitulada "Petróleo e Kafka" apontam os impasses de ordem econômica e política que permeiam a polêmica dos "contratos de risco."11 O Centro de Estudos e Defesa do Petróleo e da Economia Nacional (CEDPEN), que foi uma organização civil destinada a informar à sociedade sobre os temas relacionados à nacionalização do petróleo e defendê-la, declarou ser a decisão governamental um "erro gravíssimo... verdadeira brecha na estrutura necessariamente monolítica da empresa (Petrobras) e do monopólio estatal". ${ }^{12}$

A abertura para empresas privadas através dos "contratos de riscos" não significou a quebra do monopólio legal da Petrobras, já que Geisel propôs abertura limitada à exploração e pesquisa, mantendo a distribuição. O monopólio legal durou o período compreendido entre 1954 a 1997, quando o então presidente Fenando Henrique Cardoso instaurou a quebra do monopólio da estatal. Os contratos liberados por Geisel não surtiram efeitos significativos, apesar do interesse de empresas privadas nacionais e internacionais como a British Petroleum, Shell e Elf $^{13}$. Também em 1975 o governo responde à Crise do Petróleo com o programa Pró-Álcool estimulando a substituição dos combustíveis derivados do petróleo por álcool.

Além do interesse pela necessidade de importar petróleo o Brasil enxerga nos países árabes um potencial mercado consumidor. De acordo com a fala a

${ }^{9}$ JUSBRASIL-Disponível em: http://jb.jusbrasil.com.br/definicoes/100000159/contrato-derisco?ref=home Acessado em: 27 de janeiro de 2015.

${ }^{10}$ SENADO - Contrato com Cláusula de Risco para Exploração de Petróleo no Brasil. Disponível em: $\quad$ http://www2.senado.leg.br/bdsf/bitstream/handle/id/176365/000499438.pdf?sequence=1 Acessado em: 27 de janeiro de 2015.

11 Jornal do Brasil. Acervo Disponível em: http://memoria.petrobras.com.br/upload/acervo/contratos-de-risco-para-explorar-petroleo-nobrasil-sao-autorizados

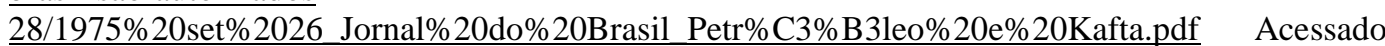
em: 06 de janeiro de 2015.

12 CPDOC/FGV Centro de Pesquisa e Documentação de História Contemporânea do Brasil Verbete: Centro de Estudos e Defesa do Petróleo e da Economia Nacional (CEDPEN)

13 CPDOC/FGV Centro de Pesquisa e Documentação de História Contemporânea do Brasil: Verbete: Petrobras 
respeito desse contexto histórico do embaixador do Brasil na Líbia entre 2006 e 2009 Luciano Rosa:

These realities led to a diplomatic offensive towards a region thet not only represented the best option for supplying Brazil with oil, but also represented a market for non-traditional exports. Soon a more precise and well-defined position on the Middle East and particularly on Palestine became imperative, because without it the strengthening of relations with Arab states would have been compromised $^{14}$.

Através das empresas privadas ENGESA e AVIBRÁS a indústria brasileira forneceu blindados e armamentos aéreos à Líbia. Esse fornecimento teria sido sigiloso e levado a público por Geisel ${ }^{15}$. Em 1977 Geisel rompe cooperação com os EUA na área de armamentos e declara já ter consolidada relações nessa área com outros países, dentre eles a Líbia. Esse cenário denota o não-alinhamento automático com os interesses norte-americanos e a diversificação das relações exteriores em busca, também, de mercados consumidores e, em especial, de produtos bélicos como apontam Gonçalves e Miyamoto:

O fosso que se abria entre a política externa pragmática e responsável brasileira e os postulados essenciais da política internacional norte-americana tendia a ampliarse na mesma proporção em que se diversificavam os interesses econômicos e aumentava a margem de independência política do Brasil no sistema internacional. Essa liberdade de eleger os aliados vistos como os mais convenientes aos seus interesses manifestara-se em relação à África e pronunciava-se, igualmente, em relação ao Oriente Médio, uma área até então situada fora do círculo das preocupações da chancelaria brasileira. A pardas crescentes exportações de manufaturados, que beneficiavam a balança de pagamentos ao reduzir as compras do exterior, principalmente de material bélico produzido pelas empresas estatais IMBEL e EMBRAER, o governo brasileiro redefiniu suas alianças na região (...) (Gonçalves e Miyamoto, 1993, p. 23).

Em 1979 assume a presidência da república o último presidente militar brasileiro João Figueiredo, cujo governo se estendeu até 1985. Sua política externa

\footnotetext{
${ }^{14}$ ROSA 1996, 443-444 apud AMAR, Paul. The Middle East and Brazil. Indiana University Press. 2014.

${ }^{15}$ GODOY, Roberto Estadão. Disponível http://www.estadao.com.br/noticias/impresso,blindados-usados-pela-libia-sao-fornecidos-pelobrasil,688430,0.htm Acessado em: 16 de outubro de 2013.
} 
foi caracterizada pelo "Universalismo" (Gonçalves e Miyamoto,1993), (Vizentini, 2004). Uma espécie de adequação ao processo de globalização em curso:

\begin{abstract}
Segundo o chanceler Saraiva Guerreiro, a linha básica da política externa sob seu comando seria o universalismo, complementado pela dignidade e pela boa convivência. Por universalismo entendia-se a adaptação da política externa brasileira à irrefreável tendência à mundialização do sistema internacional. Tal adaptação era vista como necessária e premente, em virtude do singular perfil do Estado brasileiro, em que a ambivalência constitui o traço mais destacável. Ou seja, enquanto de um lado integra o Terceiro Mundo, de outro insere-se no Ocidente desenvolvido; neste último, por compartilhar seus valores e aspirações. (Gonçalves e Miyamoto, 1993, p. 28).
\end{abstract}

Segundo Sônia de Camargo, não houve mudança efetiva da política externa brasileira entre os dois governos: "o que houve, talvez, foi uma mudança de estilo -uma diplomacia menos secreta e com um diálogo mais aberto com o Congresso Nacional". ${ }^{16}$

No que toca a vertente "Terceiro-Mundista" da política externa universalista as relações com os países da região do Oriente Médio e Ásia foram ampliadas destacando as relações com os países produtores de petróleo Irã e Iraque. (Gonçalves e Miyamoto, 1993).

O período da ditadura civil-militar no Brasil, segundo Campos (2012), é fortemente marcado pela presença e fortalecimento das empresas empreiteiras no país. É no ano de 1979 que a Odebrecht acorda os primeiros contratos no exterior com usinas hidrelétricas no Chile e Peru. Desde então, diversos projetos foram exportados pela América Latina, América do Norte, África subsaariana, Ásia e norte da África com importantes projetos na Líbia nas áreas de construção civil e infraestrutura.

Entretanto, já na década de 1980 é observado o arrefecimento das relações entre Brasil e Líbia mediante a queda do preço do petróleo e o embargo econômico norte-americano imposto à Líbia, e ratificado pelo governo brasileiro, em 1982 que ocasionou o isolamento do Líbia no cenário internacional culminando em grave crise econômica no país norte africano como apontado na seção anterior.

Além disso, os esforços de contenção por parte do governo norte-americano frente às influências de esquerda exercidas por Cuba e Líbia no Suriname. O

\footnotetext{
${ }^{16}$ CAMARGO, Sônia de. apud GONÇALVES e MIYAMOTO,1993, p. 28.
} 
governo estadunidense incentiva as relações entre Brasil e Suriname com o objetivo de contenção tendo o apoio do governo militar brasileiro:

O destaque vai para as relações havidas a partir de 1982, ano em que um novo golpe de Estado indicou que o Suriname poderia se tornar uma ditadura de esquerda, aliada de Cuba e da Líbia. Nesse momento, enquanto os Países Baixos e Estados Unidos optaram por tentar sufocar a rebelião surinamesa por meio do corte da ajuda financeira que davam ao país, o governo brasileiro enviou uma missão diplomática para aprofundar o diálogo e oferecer uma opção ao Suriname. Enquanto os Estados Unidos intervinham militarmente em Granada, a pouco mais de mil quilômetros de distância da costa surinamesa, o Brasil escolheu o caminho da cooperação para evitar a "cubanização" de seu vizinho. Conclui-se que ao longo desse período, Brasil buscou assegurar relações confiáveis com seu mais novo vizinho sem despertar protestos de hegemonia ou satelitização, orientando-se pelo objetivo da construção de confiança regional." (Urt, 2010, p. 70).

Tal esfriamento das relações entre o Brasil e a Líbia vai permanecer de forma mais ou menos oscilante durante o período de redemocratização no Brasil e os seus governos subsequentes. O presidente José Sarney assume em 1985 o primeiro governo civil pós ditadura civil-militar no Brasil. A transição de um regime ditatorial para um regime democrático suscitaria substantivas mudanças na condução da Política Externa Brasileira? Esse é o questionamento de Tullo Vigevani e Gabriel Cepaluni (2011) ao qual respondem que apesar da aparente expectativa a política externa do governo Sarney foi marcada mais por continuidades do que por descontinuidades.

Para os autores, a continuidade da condução da política externa brasileira no governo Sarney foi previsível à medida que a própria transição e o processo de redemocratização se deram de forma gradual e, portanto, as orientações da política externa acompanhariam o mesmo ritmo.

Os eventos significativos da política externa em sua gestão foram: a declaração da moratória brasileira, o contencioso das patentes farmacêuticas com os EUA, o conflito Brasil-EUA na área da informática e o posicionamento brasileiro na rodada do Uruguai no GATT. Tais eventos marcariam a pressão externa sofrida pelo governo brasileiro no sentindo de alterar o curso da busca da autonomia pela distância que era a lógica que orientava a política externa de Sarney (Vigevani e Cepaluni, 2011) cujo governo no plano doméstico carecia de legitimidade:

O próprio Sarney reconhecia a falta de confiança nele depositada, por ter construído sua carreira na Aliança Renovadora Nacional (Arena), partido oficial 
do regime militar que governou o Brasil de 1964 a 1985. Ele assume o poder em um país que duvidava de sua legitimidade e, simultaneamente, enfrentava a explosão de graves crises: a político-institucional, a econômica e a social. (Vigevani e Cepaluni, 2011, p. 41).

No governo Sarney não foram observados movimentos significativos da política externa brasileira para os países da região do Norte da África, mantendo a constância das relações entre Brasil e Líbia que já se observava no último governo militar.

Apesar das propostas de mudança da política externa brasileira durante o governo Collor, primeiro presidente eleito por voto direto, é possível observar o traço contínuo da condução da política internacional no que tange ao forte vínculo ao modelo econômico do país. O que caracterizaria e diferenciaria a política externa de Collor seria constituir ferramentas que ampliassem a competitividade internacional do Brasil. Fazia parte do amplo pacote econômico a abertura comercial, a liberalização de investimentos, privatização de empresas públicas e renegociação da dívida externa. No entanto, a crise política que se iniciava no primeiro ano de seu mandato e teria o desfecho do impeachment tornaria fortemente limitada a capacidade de negociação tanto com as elites políticas e econômicas no plano doméstico bem como frágil sua credibilidade no plano internacional. (Hirst e Pinheiro, 1995).

Com o afastamento de Collor após dois anos de governo assume a presidência em 1992 Itamar Franco. A política externa do novo presidente se pretendia "voltada para o desenvolvimento do país, para a afirmação de valores democráticos e de sentido universalista. (...) uma política externa sem alinhamentos outros que não aqueles (...) ligados à ética e aos interesses do povo brasileiro" 17 . Ou seja, seria uma política sem caracterização ou rótulos que evidenciasse total rompimento com as políticas precedentes e nem suscitasse grandes expectativas. O que caracterizou a política externa do governo de Itamar Franco foi a manutenção de políticas anteriores simultaneamente à "adoção de posicionamento marcado pela condição de país em desenvolvimento". (Hirst e Pinheiro, 1995, p. 11).

\footnotetext{
${ }^{17}$ AMORIM, 1993. apud HIRST e PINHEIRO, 1995, p.9
} 
Não há um consenso na literatura acerca das relações entre o Brasil e o continente africano na década de 1990 (Abdenur e Rampini, 2014). Por um lado, Raquel Rizzi (2005) aponta ter havido um declínio das relações Brasil-África nesse período caracterizado pela retração comercial, bem como pela diminuição do número de diplomatas brasileiros na África. Por outro lado autores como Hirst e Pinheiro (1995), Saraiva (1996) e Pimentel (2000) apontam que há, ao contrário de retração, um aumento gradativo de políticas brasileiras voltadas para o continente africano. Nesse sentido, pode-se observar que no governo Itamar Franco houve importante aproximação com a África do Sul e com os países africanos de língua portuguesa:

\begin{abstract}
Não obstante, algumas iniciativas recentes foram tomadas durante o governo Itamar Franco com vistas a reverter parcialmente esta tendência. Os principais casos a exemplificar esta alteração foram a aproximação com a África do Sul e a participação no processo de pacificação de Angola. Com o fim do apartheid na África austral, relançando a proposta de criação da Zona de Cooperação do Atlântico Sul com vistas a abrir um canal comum entre os países do Cone Sul e esta região. Deve-se ressaltar a busca de cooperação na área tecnológica, agropecuária e de combate ao narcotráfico e, principalmente, o esforço da diplomacia brasileira, através de seu Departamento de Promoção Comercial, de aproximar o empresariado dos dois países em direção a empreendimentos conjuntos com base na crença de que a África do Sul deverá liderar um processo de integração econômica no continente, semelhante ao MERCOSUL. No caso de Angola, vale mencionar a atuação do Brasil em prol da pacificação nacional, tendo inclusive apoiado a advertência por parte do Conselho de Segurança da ONU (julho de 1993) ao líder da UNITA, ameaçando o grupo com embargo, caso não abandonasse a ação militar e não respeitasse o resultado das eleições de setembro de 1992. A propósito, coube a um oficial brasileiro o primeiro comando militar da Unavem, em Angola, o que também ocorreu em Moçambique. Uma outra iniciativa importante no processo de revitalização da política africana do Brasil foi a proposta de criação da chamada Comunidade dos Povos de Língua Portuguesa (março de 1993). Impulsionada por uma motivação histórico cultural, a Comunidade pretende estabelecer uma maior coordenação entre os seus membros no manejo de temas de política internacional. (Pinheiro e Hirst, 1995, p.19).
\end{abstract}

A política externa de Fernando Henrique Cardoso, que assume a presidência do Brasil em 1995, é caracterizada pela ideia da "Autonomia pela Integração". Parâmetros tradicionais tais como pacifismo, zelo pelo direito internacional, defesa dos princípios de autodeterminação e não-intervenção e o pragmatismo foram mantidos, no entanto operados de maneira distinta da "Autonomia pela Distância" que esteve em vigor até 1988. 
Aumentando sua participação nas mais diversas arenas normativas buscouse participar e contribuir para um ambiente internacional cada vez mais institucionalizado e favorável para o desenvolvimento econômico do país, objetivo este presente na política externa brasileira em todo o século XX. Do mesmo modo, a relação com os países africanos se manteve secundária apresentando, no entanto, movimentos de cooperação com os países da CPLP (Comunidade dos Países de Língua Portuguesa), com a África do Sul, Angola e com a Nigéria, onde a Petrobras atuou na prospecção e importação de petróleo. (Vigevani et al, 2003).

O arrefecimento das relações entre Brasil e Líbia observado ainda na década de 1980 permanece em toda a década subsequente. Como anteriormente mencionado, um dos possíveis motivos ainda na década de 1980 foi a participação brasileira na contenção norte-americana da influência da Líbia e de Cuba no Suriname. Além disso, o próprio isolamento internacional de Kadaffi ajuda a compreender a retração das relações bilaterais entre Brasil e Líbia nesse período. (Casarões, 2014).

Apesar do esfriamento, cabe ressaltar que no ano de 1989 iniciam-se no Brasil as atividades do Banco ABC, um banco de investimentos criado em parceria entre o Arab Banking Corporation e o grupo Roberto Marinho ${ }^{18}$. Em 1997 o Arab Banking torna-se acionista controlador ao adquirir participação acionário do Grupo Roberto Marinho. Um dos principais acionistas do Arab Banking é o Banco Central da Líbia ${ }^{19}$.

Ao longo dos anos 1990, em decorrência das sanções norte-americanas à Líbia através da Resolução 748 do Conselho de Segurança da ONU, o embaixador brasileiro foi retirado do território líbio. No entanto, em 05 de maio de 1999 as sanções foram suspensas com a entrega dos suspeitos de Lockerbie e em 2000, e durante o governo de Fernando Henrique Cardoso, foi novamente enviado um embaixador brasileiro ao território líbio.

Apesar desses importantes eventos, é no governo brasileiro subsequente que as relações Brasil-Líbia serão significativamente retomadas. Como apontado

\footnotetext{
${ }^{18} \mathrm{ABC} \quad$ Banco ABC Brasil - Disponível em: http://www.abcbrasil.com.br/show.aspx?idCanal=yy8GhdCZO4Z8I1bQoASoFw== Acessado em: 21 de julho de 2014.

${ }^{19}$ Arab Banking Corporation - Disponível em: http://www.arabbanking.com/En/Pages/default.aspx Acessado em 21 de julho de 2014.
} 
anteriormente, o contexto pós Guerra Fria inaugura um cenário internacional caracterizado pelo multipolaridade e pelo protagonismo das então denominadas "potências emergentes". Com a ascensão do Partido dos Trabalhadores ao poder no Brasil em 2003 há importante enfoque da política externa para a atuação cada vez mais proeminente no sistema internacional e um dos principais instrumentos para tal é a Cooperação Sul-Sul. Nesse momento as relações do Brasil com os países do continente africano, incluindo a Líbia, são fortemente intensificadas. Esse é o período privilegiado neste trabalho e será analisado sob a perspectiva do nexo desenvolvimento-segurança no capítulo seguinte.

\section{3}

\section{Conclusão}

Este panorama histórico evidenciou a dinâmica de continuidades e descontinuidades entre as relações Brasil e Líbia entre 1969 e 2002 fortemente marcada pelo contexto de mudança da política mundial.

As transformações do cenário internacional que nas décadas de 1960 e 1970 possibilitaram maior flexibilização do alinhamento da política externa brasileira com os EUA bem como a crise do petróleo contribuíram para uma maior diversificação das relações políticas e econômicas do Brasil, especialmente com os países árabes. É nesse contexto que a cooperação com a Líbia se estabelece de forma significativa.

O fim da Guerra Fria trouxe profundas transformações do sistema internacional abrindo espaço cada vez maior para o protagonismo das "potências emergentes" bem como para a cooperação entre os países em desenvolvimento. No entanto, esse cenário não se configurou de forma imediata.

O período compreendido entre o final dos anos 1980 e início dos anos 1990, imediatamente após à Guerra Fria, marcou uma retração das relações entre o Brasil e a Líbia. Isso foi devido em grande medida pela queda do preço do petróleo, do embargo do EUA à Líbia e ratificado pelo Brasil que colimou em significativo isolamento do país norte africano, bem como pelos esforços de contenção do governo norte-americano à influência de esquerda na América Latina que resvalou nas relações entre os dois países. 
É somente no governo Lula em 2003 que de fato que relações entre Brasil e Líbia são fortemente incrementadas. A Cooperação Sul-Sul é utilizada pela política externa brasileira com um importante instrumento de atuação no cenário internacional e nesse contexto a Líbia, o país com o segundo maior PIB (Produto Interno Bruto) per capita do continente africano e com baixíssimo endividamento externo, retoma profícua parceria com o Brasil

Através dessa análise, portanto, foi possível concluir que o governo Lula não inaugura essa relação que se estabeleceu desde longa data. Cabe ressaltar a importância fundamental da comercialização do petróleo para a consolidação dos laços entre os dois países, importância essa que vai perdurar em todas as fases de cooperação incluindo a fase do governo PT, bem como o fato de que foi durante o governo Médici que observou-se os primeiros movimentos mais significativos decorrentes que se intensificaram dos desdobramentos da Crise do Petróleo já no governo Geisel.

Portanto os três últimos governos militares, com especial destaque ao governo Geisel, foram marcados por movimentos significativos de aproximação com as regiões do Oriente Médio e Norte da África. A Crise do Petróleo foi de fato um catalisador para a busca de um modelo de desenvolvimento econômico que estreitou os laços entre o Brasil e a região preenchendo assim um vácuo diplomático na política externa brasileira. (Santana, 2014).

Também coube notar que as relações Brasil-Líbia não obedecem um continuum, ao contrário, observou-se encontros e desencontros motivados pelos contextos domésticos de cada país bem como pelo contexto internacional.

O capítulo seguinte irá privilegiar o marco temporal que é o foco desta dissertação inaugurado com o governo Lula, marcado pelo ponto de inflexão dos desdobramentos da Primavera Árabe na Líbia em 2011 e a morte de Muammar alKadaffi, e o governo Dilma. Da mesma forma, será enfatizada a análise da política externa brasileira dos dois governos, suas aproximações e distanciamentos. 


\section{As Relações Brasil e Líbia nos governos Lula e Dilma sob a perspectiva do Nexo Segurança-Desenvolvimento}

O contexto pós Guerra Fria além da multipolaridade e da emergência de novos atores alcançando protagonismo no sistema internacional, tanto no campo do desenvolvimento quanto no da segurança, também é caracterizado pelo aumento de conflitos intra-estatais e nesse sentido o intervencionismo tornou-se mais frequente. Com o e evento do 11 de setembro e a subsequente Guerra ao Terror há um franco processo de securitização da agenda do desenvolvimento como aponta Duffield (2007; 2010).

Após um breve panorama das relações entre Brasil e Líbia em perspectiva histórica à luz das transformações da condução da política externa brasileira, este capítulo objetiva analisar as relações entre os dois estados durante os governos Lula e Dilma, portanto durante o período compreendido entre os anos de 2003 a 2014. Tal recorte temporal tem um ponto de inflexão fundamental que é a Primavera Árabe e seus desdobramentos na Líbia que culminaram na intervenção da OTAN em 2011. Neste mesmo ano no Brasil ocorre a transição de governo entre Lula e Dilma o que trará mudanças significativas na política externa brasileira para o Norte da África e países árabes em geral, passando por questões fundamentais atreladas ao nexo entre desenvolvimento e segurança.

O discurso da política externa brasileira é historicamente marcado pela defesa da soberania, prevista pela constituição brasileira, e da não-intervenção posicionamento que condiz com seu passado colonial compartilhado com grande parte dos países do Sul Global. Por outro lado, é cada vez maior a demanda internacional de um posicionamento brasileiro no que toca à defesa dos direitos humanos, elemento também previsto pela constituição brasileira, mas que por vezes torna-se conflitante com a defesa da soberania. O caso em particular das relações com a Líbia ao mesmo tempo em que aponta para a priorização da agenda de desenvolvimento por meio da Cooperação Sul-Sul durante o governo Lula, 
evidencia aspectos fundamentais acerca da intervenção e defesa dos direitos humanos marcadamente na transição para o governo Dilma. Nesse sentido, será feito neste capítulo um esforço analítico para responder a questão central desta pesquisa: Em que medida a cooperação para o desenvolvimento oferecida à Líbia pelo Brasil corresponde ao discurso oficial da diplomacia brasileira no que diz respeito às intervenções humanitárias?

Para tal, na primeira seção “O Amigo Irmão” será analisado o período do governo Lula, sua condução da política externa brasileira e os seus desdobramentos sobre as relações entre o Brasil e a Líbia. Na segunda seção, "A Primavera Árabe”, será dado destaque aos desdobramentos dos movimentos sociais que marcaram os países árabes a partir do ano de 2010 e seu particular resultado na Líbia. Na seção "O Ouro Negro e as Empreiteiras" serão analisadas as duas principais frentes de atuação do Brasil na Líbia: exploração de petróleo e construção civil. A seção intitulada "O governo Dilma e a era pós-Kadaffi" será destinado a discutir as relações entre o Brasil e a Líbia no contexto de intervenção e pós intervenção da OTAN e as transformações na condução da política externa brasileira com especial destaque para o posicionamento da PEB acerca da Responsabilidade de Proteger, conceito aplicado pela primeira vez no contexto líbio. Na seção “O Brasil e o Nexo no Caso da Cooperação com a Líbia" será feito um esforço analítico de compreensão de como a política externa brasileira articula o nexo segurançadesenvolvimento no caso da cooperação com a Líbia. Por fim, a seção conclusiva irá apontar algumas possíveis respostas ao questionamento central desta dissertação.

\section{1}

\section{"O Amigo Irmão"}

Durante os dois mandatos do governo Lula iniciado em 2003 e cuja política externa é considerada proativa e pragmática (Hirst, Lima e Pinheiro, 2010), foi dado um impulso fortemente significativo na Cooperação Sul-Sul. Houve significativa ênfase da política externa brasileira na cooperação com o continente africano (Abdenur e Souza-Neto, 2013) com foco na região da África subsaariano. No entano, tal movimento de intensificação da Cooperação Sul-Sul incluiu importante 
aumento das relações com os países árabes, dentre eles os países árabes no norte da África. Segundo Montibeler e Gallego (2012):

La cancelaria del gobierno Lula durante los ocho años de gobierno fue hasta las "últimas" consecuencias en la búsqueda el fortalecimiento de las relaciones bilaterales entre Brasil y los países árabes. Es posible arriesgar que difícilmente hubo en la historia de Brasil esfuerzo similar en avanzar, principalmente, en el fortalecimiento de las relaciones económicas: comerciales y de capitales. (Montibeler e Gallego, 2012, p. 1)

Em artigo publicado pelo Valor Econômico em 2003 intitulado "Uma agenda de cooperação com o mundo árabe" o então Ministro das Relações Exteriores Celso Amorim apontou o grande interesse do governo brasileiro em estreitar os laços com a região mantendo a perspectiva de cooperação:

\begin{abstract}
Ao acercar-se dos países árabes, o Brasil inspira-se no firme propósito do presidente Lula de trabalhar pela paz internacional e de levar adiante nossa luta pelo desenvolvimento econômico com justiça social, diversificando nossos relacionamentos e fortalecendo parcerias com os países do sul. As afinidades históricas que unem o Brasil aos países árabes merecem ser postas a serviço de projetos concretos nas esferas econômico-comercial, científico-tecnológica, social e cultural, e, sobretudo, de um diálogo político de alto nível que contribua, de algum modo, para a paz naquela região ${ }^{20}$.
\end{abstract}

Tal cooperação opera em diversas frentes a saber: econômica, política e cultural. Na frente econômica há importante crescimento das trocas comercias entre o Brasil e os países árabes. O gráfico abaixo aponta o aumento significativo desse fluxo:

\footnotetext{
${ }^{20}$ AMORIM, Celso Discursos, Palestras e Artigos do Chanceler Celso Amorim Volume I Departamento de Comunicação e Documentação - Ministério das Relações Exteriores - Brasília 2011.
} 


\section{Figura 2 - Gráfico de fluxo comercial entre Brasil e Países Árabes}

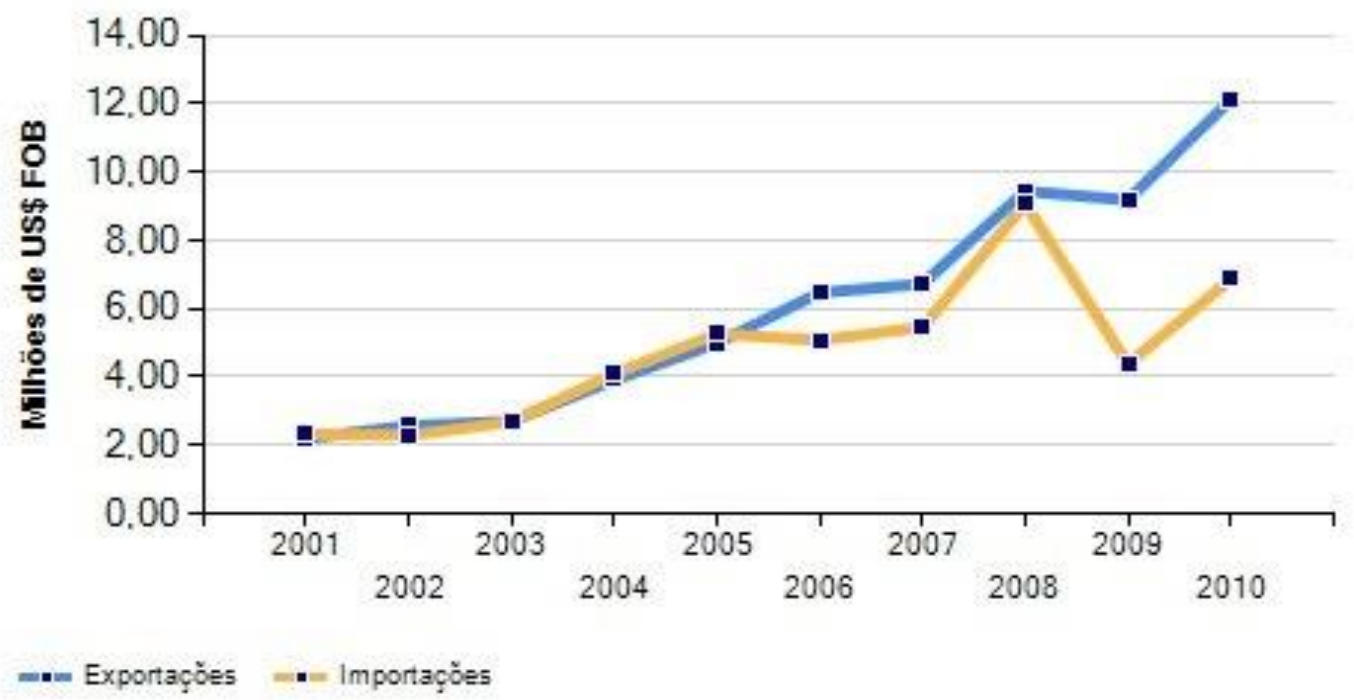

Fonte: CCAB in Elias Montibeler, Everlan, Solano Gallego, Esther (2012), "Relaciones bilaterales entre Brasil y Liga Árabe: un análisis a partir de la teoría de la internacionalización de la producción y de la diversificación comercial”, Observatorio de la Economía Latinoamericana, n 163 , p.8

Basicamente, o principal produto que o Brasil importa da Líbia é o petróleo e seus derivados enquanto que há maior diversificação nos produtos de exportação como apontam as figuras a seguir:

Figura 3 - Importações Brasil - Países Árabes 2011

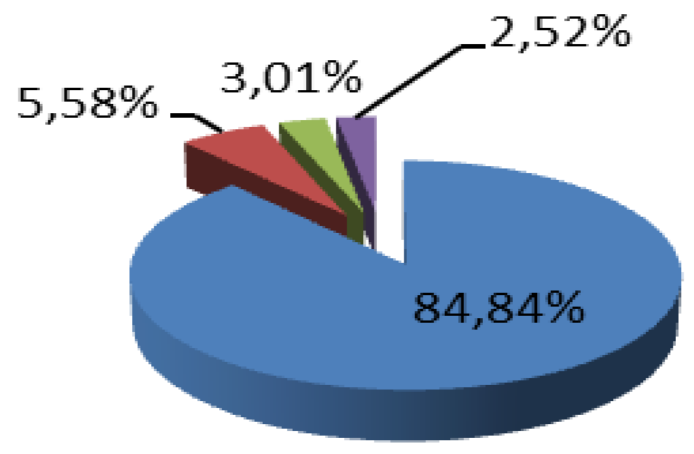

Combustibles minerales

Adobos y fertilizanes

Sal, azufre

Productos químicos

Fonte: Casa Árabe in Elias Montibeler, Everlan, Solano Gallego, Esther (2012), "Relaciones bilaterales entre Brasil y Liga Árabe: un análisis a partir de la teoría de la internacionalización de la producción y de la diversificación comercial", Observatorio de la Economía Latinoamericana, $\mathrm{n}^{\circ} 163$, p.10 
Figura 4 - Exportações Brasil - Países Árabes 2011

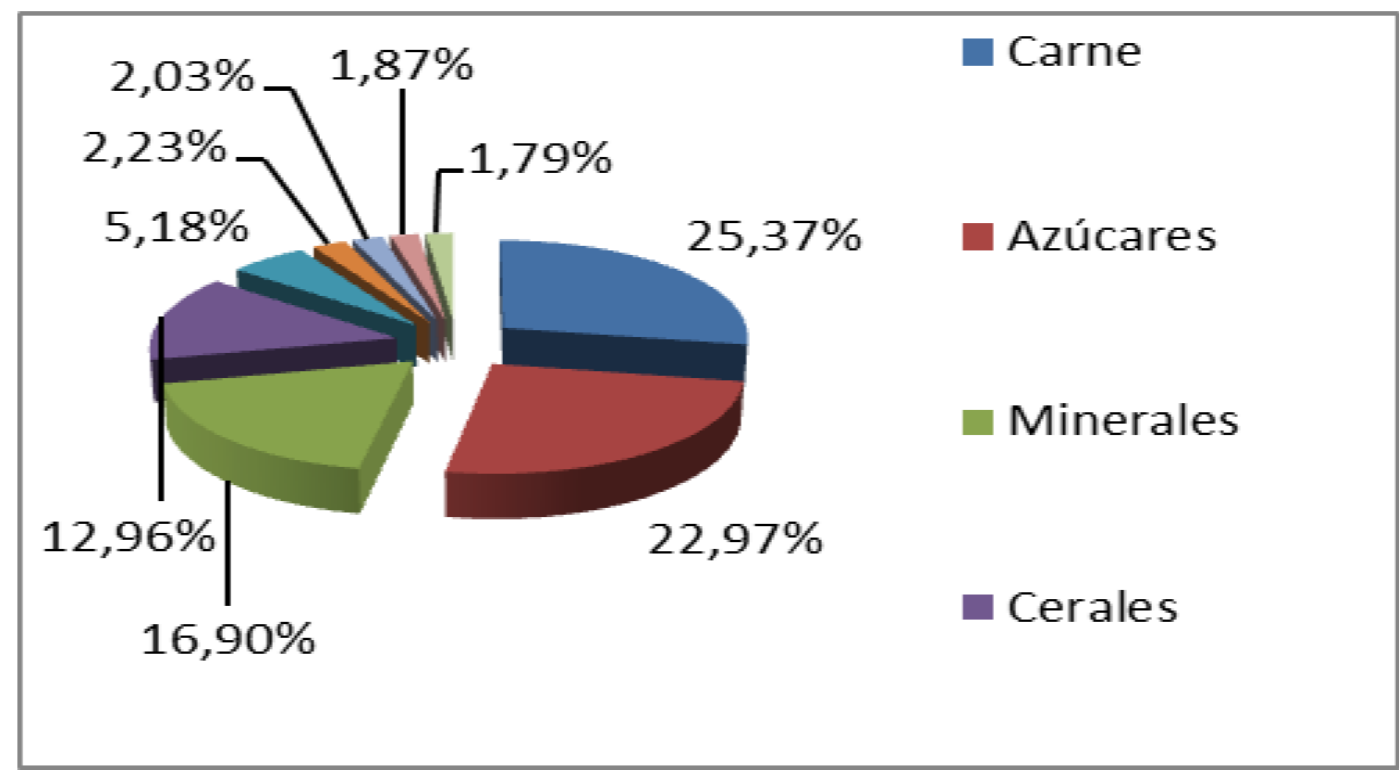

Fonte: Casa Árabe in Elias Montibeler, Everlan, Solano Gallego, Esther (2012), "Relaciones bilaterales entre Brasil y Liga Árabe: un análisis a partir de la teoría de la internacionalización de la producción y de la diversificación comercial", Observatorio de la Economía Latinoamericana, $\mathrm{n}^{\circ} 163, \mathrm{p} .10$

$\mathrm{Na}$ frente política, o estreitamento das relações com os países árabes significa para o Brasil não apenas maior autonomia no cenário internacional, mas também aponta para a ambição de se tornar um ator de maior relevância no âmbito da segurança internacional, por esse motivo os objetivos de se envolver em questões de mediação de conflitos, especialmente no Oriente Médio. Tal ambição reflete-se fortemente no pleito a um assento permanente no Conselho de Segurança da ONU, que será analisado com mais detalhes na última seção deste capítulo.

Em dezembro de 2003, em viagem histórica (que incluiu Egito, Síria, Líbano, Emirados Árabes e Líbia) ${ }^{21}$ Lula discursa na sede da Liga Árabe (da qual o Brasil participa como país observador) no Egito enfatizando não apenas o potencial comercial das relações entre o Brasil e os países pertencentes ao bloco, mas também as trocas culturais e políticas além de claramente expor que a ideia de Sul Global e de sua integração:

\footnotetext{
21 RODRIGUES, Fernando Folha de São Paulo - Disponível em: http://www1.folha.uol.com.br/folha/brasil/ult96u56038.shtml Consultado em 30 de outubro de 2013.
} 
Esta viagem que estamos fazendo pelo mundo árabe eu considero uma viagem histórica, porque o último chefe de Estado brasileiro a vir por estas bandas foi o imperador Dom Pedro II, em 1876. Esta nossa viagem, com governadores, ministros e empresários brasileiros, tem como objetivo começar uma discussão para que possamos tornar a geografia comercial do mundo mais justa, mais igualitária e mais equânime com os representantes do Mercosul. (...) É com imensa satisfação que visito a Liga dos Estados Árabes, uma das mais importantes organizações multilaterais do mundo. É uma honra fazer este pronunciamento como primeiro chefe de Estado brasileiro a visitar esta nobre instituição. Países Árabes e Brasil têm profundos vínculos históricos e culturais. São laços de que nos orgulhamos. Eles explicam a cordialidade e o respeito com que nos relacionamos. (...) O Brasil precisa criar e reforçar parcerias concretas nos campos econômico, social, cultural e político com os países do $\mathrm{Sul}^{22}$.

Ainda em 2003, é proposta pelo governo brasileiro a criação da ASPA (Cúpula América do Sul-Países Árabes). Segundo o Ministério das Relações Exteriores do Brasil a ASPA é um mecanismo de Cooperação Sul-Sul e de coordenação política em foros multilaterais, objetivando promover a aproximação das sociedades civis e lideranças políticas das duas regiões, como também a concertação diplomática em temas de interesse comum. Na I Cúpula da ASPA em Brasília, em foi definida sua estruturação formal com a composição de 34 países, dentre eles 12 sul-americanos (incluindo o Brasil) e 22 países membros da Liga Árabe (incluindo a Líbia). Também foram reconhecidas como membros a UNSASUL (União de Nações Sul-Americanas) e a LEA (Liga dos Estados Árabes $)^{23}$.

Segundo Paulo Farah (2014) convergências de agendas políticas e econômicas estavam embutidas nesta visão bi regional (Farah, 2014, p. 40). O autor ainda destaca a fala do presidente Lula em que qualifica a ASPA enquanto um instrumento que possibilita os países do Sul Global a lidar em condições de igualdade com os países do Norte Global: “The global vocation of Brazil is to work

\footnotetext{
${ }^{22}$ Discurso do Presidente da República, Luiz Inácio Lula da Silva, na visita à sede da Liga dos Estados Árabes Cairo-Egito, 09 de dezembro de 2003. Presidência da República. Secretaria de Imprensa e Divulgação. Disponível em:http://www.biblioteca.presidencia.gov.br/expresidentes/luiz-inacio-lula dasilva/discursos/1o-mandato/pdfs-2003/2o-semestre/09-12-2003discurso-do-presidente-da-republica-luiz-inacio-lula-da-silva-na-visita-a-sede-da-liga-dos-estadosarabes Acessado em: 10 de janeiro de 2015.

23 MRE -Ministério das Relações Exteriores -Itamaraty Disponível em: http://www.itamaraty.gov.br/index.php?option=com content $\&$ view=article $\& i d=3675$ :cupulaamerica-do-sul-paises-arabes-aspa\&catid=172\&lang=pt-br\&Itemid=436 Acessado em: 10 de janeiro de 2015.
} 
on the creation of an Arab-South American bloc in conjunction with Third World countries to deal on qual terms with countries of the North." (Ibid.).

Paul Amar (2014) aponta que a relação entre a América Latina e os países árabes revela uma nova forma transnacional de solidariedade que objetiva contrabalancear o Norte Global além de buscar alternativas à maciça presença da China na região e configurar-se como um novo campo de estudos transregionais como, por exemplo, na troca de expertise na área de segurança entre as duas regiões.

Nesse contexto, depois de um arrefecimento de suas relações entre o final da década de 1980 e a década de 1990, há um incremento significativo das relações comerciais entre Brasil e Líbia. No ano de 2005 a Petrobras, em parceria com a estatal líbia National Oil Corporation, retoma a exploração de óleo e gás na costa do território líbio. Entre os anos de 1989 e 2002 a exportação média de produtos brasileiros para a Líbia tinha uma média anual de US\$ 56 milhões. Durante o governo Lula a média anual passou a equivaler US\$232 milhões atingindo o valor de US\$ 456 milhões em 2010. As importações também tiveram expressivo aumento. Entre o mesmo período de 1989 a 2002 a média anual de importações era de US\$ 8 milhões. No governo Lula a média sobe US\$ 468 milhões atingindo nada menos que US\$ 1,4 bilhão em 2008 trazendo ineditamente déficit na balança comercial brasileira, historicamente superavitária no comércio com a Líbia. (Casarões, 2014, p. 47). Cabe ressaltar que, além da crescente presença da China na África como um fator de intensificação da Cooperação Sul-Sul na região, com todas as sanções contra a Líbia revogadas em 2003 Kadaffi inaugura um processo de abertura econômica e de privatização destacado no capítulo anterior que abre as portas para o investimento externo.

Segundo Guilherme Casarões (2014), esse grande fluxo não deve ser compreendido apenas pela ótica comercial, mas pela perspectiva estratégica política da Cooperação Sul-Sul:

Observou-se, ademais, uma mudança de estratégia de inserção internacional: ao caráter prioritariamente comercial da PEB de outrora, fortemente associado à participação brasileira em foros multilaterais, foi somada uma dimensão política e bilateral de relevo, marcando a busca pela diversificação de parcerias e pelo retorno à cooperação sul-sul. (Ibid.)

Nesse sentido, cabe ressaltar não apenas as trocas comerciais, mas o caráter simbólico de importante impacto político contido na reaproximação do Brasil e 
Líbia durante o governo Lula. No primeiro ano de mandato de Lula foi revogado em todo o território nacional brasileiro o regime de sanções ao governo Kadaffi através do Decreto ${ }^{\circ} 4.865$ em consonância com a Resolução 1.506 do Conselho de Segurança da ONU que revogou as sanções impostas à Líbia nos anos de 1992, 1993 e $1999^{24}$. Em todo o seu mandato Lula teve 4 encontros com o Kadaffi, e em um desses encontros, ao discursar na abertura da Cúpula da União Africana em julho de 2009 na cidade líbia Sirte, Lula se refere a Kadaffi como amigo e irmão. O que gerou críticas e estranhamentos domésticos e internacionais. (Casarões, 2014).

Já em 2009, durante o segundo mandato de Lula, é assinado pelos dois Estados um protocolo de intenções de cooperação técnica na área da saúde. Os principais objetivos do acordo eram: promover e facilitar relações mais estreitas entre as respectivas instituições nacionais, regionais e locais envolvidas na cooperação técnica, com ênfase a questões relativas à malária, à AIDS e outras doenças transmitidas por vetores, compartilhar informações em áreas identificadas como prioritárias para a cooperação técnica; e promover a adoção de medidas estratégicas para permitir que as partes desenvolvam as atividades de cooperação técnica, respeitando as suas capacidades ${ }^{25}$. No entanto, o projeto não foi levado adiante ${ }^{26}$.

Em contrapartida, há também interesses do governo Líbio de atuar no Brasil. Entre os anos de 2003 e 2004 foi negociado um projeto de irrigação na região noroeste da Bahia. Este projeto foi elaborado no âmbito de uma parceria públicoprivada entre a Companhia de Desenvolvimento dos Vales do São Francisco e da Parnaíba (Codevasf), que é uma empresa pública brasileira vinculada ao Ministério da Integração Nacional, e a Lafico (Companhia Árabe-Líbia de Negócios

\footnotetext{
${ }^{24} \mathrm{JUSBRASIL} \quad$ Decreto $\quad \mathrm{n}^{\circ} 4.865 \quad-\quad$ Disponível em: http://www.jusbrasil.com.br/topicos/10975873/artigo-1-do-decreto-n-4865-de-29-de-outubro-de2003. Acessado em 12 de janeiro de 2014.

${ }^{25}$ MRE - Ministério das Relações Exteriores. Protocolo de Intenções entre o Governo da República Federativa do Brasil e a Grande Jamaíria Árabe popular Socialista da Líbia sobre Cooperação Técnica na Área da Saúde. 2009. Disponível em: http://dai-mre.serpro.gov.br/atosinternacionais/bilaterais/2009/b_6290/ Acessado em: 16 de outubro de 2013.

${ }^{26}$ Foi requerido do Sistema de Informação ao Cidadão SIC informações a respeito do protocolo e foi informado que o projeto não foi executado. Foi estabelecido contato com a Assessoria de Assuntos Internacionais da Saúde do Ministério da Saúde do Brasil, mas não foram cedidas explicações acerca da não implementação do projeto.
} 
Estrangeiros $)^{27}$ que é um órgão do governo líbio que regula os investimentos internacionais do país. Foram previstos no período compreendido entre 2011 e 2014 o investimento de $\mathrm{R} \$ 140.270 .000,00$ segundo informações do Programa da Aceleração do Crescimento do Ministério do Planejamento ${ }^{28}$. O investimento por parte do governo Líbio seria divido com empresas privadas brasileiras que têm forte presença na Líbia:

A Companhia Árabe-Líbia de Investimentos Estrangeiros (Lafico, na sigla em inglês) quer colocar até US\$ 450 milhões em projetos de irrigação no Brasil, mas não pretende investir sozinha. Nos cerca de dez dias em que ficaram no país, executivos da empresa estatal começaram a negociar parcerias com as empreiteiras brasileiras Andrade Gutierrez e Odebrecht para participar das obras, disse à ANBA o embaixador da Líbia no Brasil, Mohamed Saad Matri ${ }^{29}$.

O segundo mandato de Lula termina em 2010 e no ano seguinte assume o governo a também petista Dilma Roussef. No mesmo ano irrompem na Líbia os manifestos contra o governo Kadaffi no bojo das manifestações que atingiram o Oriente Médio e Norte da África. Tal movimento de manifestações foi denominado Primavera Árabe e seus desdobramentos na Líbia terão grande impacto em suas relações com o Brasil. Na seção seguinte, será dado destaque às análises acerca da Primavera Árabe e seus efeitos sobre a Cooperação Sul-Sul Brasil-Líbia.

\section{2}

\section{A Primavera Árabe}

Um jovem tunisiano responsável por prover os recursos financeiros de sua família, insatisfeito com os empecilhos impostos pelo governo ao seu trabalho de vendedor frutas, em dezembro de 2010 incendeia seu próprio corpo em protesto contra as arbitrariedades do Estado. Sua morte mobilizou uma série de protestos

\footnotetext{
${ }^{27}$ CODEFASV Disponível em: http://www.codevasf.gov.br/noticias/2006/baixio-deirece/?searchterm=Lafico Acessado em: 21 de julho de 2014.

${ }^{28}$ PAC -Programa de Aceleração do Crescimento -Ministério do Planejamento - Disponível em: http://www.pac.gov.br/obra/8071 Acessado em: 21 de julho de 2014.

29 NAPOLITANO, Giuliana. ANBA - Agência de Notícias Brasil-Árabe. Disponível em: http://anba.com.br/noticia/7390980/especiais/estatal-libia-negocia-joint-venture-com-odebrecht-eandrade-gutierrez/?indice=20. Acessado em:21 de julho de 2014.
} 
que pôs fim ao governo de 24 anos do chefe-de-estado tunisiano Zine el-Abdine Ben Ali. O que o jovem Mohamed Bouazizi não previu foi a subsequente onda de manifestações que ultrapassaram as fronteiras da Tunísia e alcançaram vários países árabes, cada qual com suas motivações próprias, e que foi denominada Primavera Árabe em alusão à Primavera de Praga de 1968.

Países árabes do Norte da África e Oriente Médio como Egito, Líbia, Síria, Iêmen, dentre outros, passaram pela onda de protestos que geraram queda de seus governos ou intensa instabilidade política. Algumas características comuns podem ser traçadas, como o importante papel exercido pelas redes sociais no que tange à mobilização de pessoas em grande escala e a horizontalidade dos movimentos, sem uma liderança pessoal ou partidária claramente definida. (Campbell, 2012).

Segundo Jason Pack (2014), o processo de abertura e flexibilização de regimes nacionalistas árabes tal qual ocorreu na Líbia, gerou um ambiente de vazio ideológico que facilitou a derrubada de governos estabelecidos há décadas:

It should therefore be unsurprising that half-hearted attempt by Mubarak, Ben Ali, and Qadhafi to abandon the hegemonic domination of the public sphere by the regime and to replace older forms of "genuine" Arab Nationalist socialism with bits and pieces of Washington Consenus economic policies facilitated their overthrow. Althogh these infitahs (limited market-based reforms) may have brought more resources into the regime coffers, they emptied the old regimes of any vestige of ideological legitimacy os consistency while creating dangerous new avenues for the popilace to acess information. Into the ideological vacuum, markets facilitated the flow of not only goods but also new ideas and increased expectations. (Pack, p. 4, 2014).

Em fevereiro de 2011 manifestações contra o governo de Muammar Kadaffi tomaram importantes cidades da Líbia, como a capital Trípoli e Benghazi. Forças pró-Kadaffi reagiram violentamente instaurando uma guerra civil no país ${ }^{30}$. Foi formado o Conselho Nacional de Transição (CNT) que concentrou os grupos de oposição e que destitui governo de Kadaffi. O primeiro país a reconhecer o CNT foi a França ${ }^{31}$ e logo depois a ONU também o reconhece. Em 7 de março do mesmo ano a Resolução $1973^{32}$ do Conselho de Segurança da ONU que previa zona de

30 ALJAZEERA. Disponível em: http://blogs.aljazeera.com/blog/middle-east/live-blog-libya Acessado em: 23 de dezembro de 2012.

${ }^{31}$ BBC Disponível em: http://www.bbc.co.uk/news/world-africa-12699183 Acessado em: 23 de dezembro de 2014.

${ }^{32}$ CSNU - United Nations - Security Council S/RES/1973 (2011) 17 Março de 2011. 
exclusão aérea no território Líbio autorizou a intervenção militar da OTAN que culminou na morte de Kadaffi.

O caso da Líbia é emblemático, pois pela primeira vez a OTAN intervém sob argumento da Responsabilidade de Proteger, o que trouxe inúmeros debates no âmbito político e acadêmico. Lisa Anderson (2011) questiona o caráter inovador da Primavera Árabe na Líbia enquanto que Ronald St John (2014) aponta as peculiaridades do caso líbio. Por outro lado, Vijay Prashad (2012) traz seguinte o questionamento: Por que a Líbia foi o único alvo de intervenção da OTAN dentre os países que passaram pela Primavera Árabe? Por sua vez, Horace Campbell (2012) aponta as principais motivações políticas e econômicas internas que motivaram as manifestações na Líbia e o projeto por trás da intervenção da OTAN.

Serão explanados os diferentes posicionamentos dos autores acima citados a fim de compreendermos as recentes propostas de análise das especificidades e efeitos da Primavera Árabe na Líbia. Cabe ressaltar que se trata de um esforço analítico diante de eventos muito recentes.

Lisa Anderson (2011) aponta que a onda de contestação política que recebeu o título de Primavera Árabe não seriam uma novidade já que movimentos semelhantes foram observados em outros momentos da História como os que ocorreram na Tunísia, Egito e Líbia em 1919. Nem mesmo o papel das redes sociais e da tecnologia seria capaz de imprimir um caráter inovador.

Além disso, tal nomenclatura pode induzir ao erro de igualar as manifestações de 2011 como um único bloco de movimentos políticos travados no mundo árabe negligenciando as especificidades locais. A partir dessas observações, Anderson traz uma breve análise dos desdobramentos observados em cada um dos três países acima citados. Diferentemente da Tunísia e do Egito, o conflito na Líbia foi fortemente marcado pelas clivagens étnicas que alimentaram a disputa política inflamando a sangrenta guerra civil:

Libyan society has been fractured, and every national institution, including the military, is divided by the cleavages of kinship and region. As opposed to Tunisia and Egypt, Libya has no system of political alliances, network of economic associations, or national organizations of any kind. Thus, what seemed to begin as nonviolent protests similar to those staged in Tunisia and Egypt soon became an all-out secession -- or multiple separate secessions -- from a failed state. (Anderson, 2011, p. 5). 
A última frase em que a autora denomina a Líbia como um estado falido demonstra o tom da sua análise, fortemente liberal, e com caráter prescritivo ao apontar a necessidade dos EUA compreenderem as especificidades de cada movimento local a fim de atingir seus objetivos na região.

Segundo Ronald St John (2014) ao se comparar o caso Líbio aos levantes populares que ocorreram nos países árabes como Egito, Síria, Tunísia e Yemen certamente pontos em comum serão encontrados.

Para o autor, demandas socioeconômicas sob regimes autocráticos somadas ao acesso ás redes sociais como o Facebook e Twitter que facilitaram a comunicação interna e externa são pontos de convergência. No entanto, três aspectos fundamentais distinguem o caso da Líbia: em primeiro lugar as organizações civis nos outros países árabes tiveram importante participação nos movimentos populares enquanto que na Líbia grupos representantes da sociedade civil praticamente eram inexistentes, logo após a queda de Kadaffi inúmeras entidades civis foram fundadas. O segundo aspecto é o fato da Líbia ter uma enorme reserva de hidrocarbonetos o que o torna o país mais ricos dentre os outros países que passaram pela Primavera Árabe. E por fim, o aspecto religioso também torna o caso da Líbia peculiar:

\begin{abstract}
Libya has a homogeneous Muslim society with 99 percent of the population Muslim and 97 percent Sunni Muslim. This is in contrast to the religious divisions found in Egypt (Coptic Christians, Sunni Muslims, and Muslim minorities) and Syria (Alawites, Druze, Christians, and Sunni Muslims). In part due to this homogeneity, fundamentalist Islamist movements and radical organizations like Al-Qaeda have found only limited indigenous support in Libya, unlike Egypt (the Muslim Brotherhood, Salafists), Tunisia (Al-Nahda, Al-Qaeda in the Islamic Maghreb), and Yemen (Al-Nahda, Al-Qaeda in the Arabian Peninsula) Tribal identities also remain strong in Libya, similar to Yemen, but unlike in Egypt, Syria, and Tunisia. (St John in Jason Pack, 2014, p. 97).
\end{abstract}

Em contrapartida, sobre a Primavera Árabe e a Intervenção da OTAN Horace Campbell (2012) explica aspectos políticos e econômicos internos na Líbia que 1) mobilizaram os movimentos da Primavera Árabe e 2) motivaram a intervenção que, segundo o autor, atende um objetivo maior de militarização da África, exploração de petróleo, e de inserção de modelo econômico ocidental na África. $\mathrm{O}$ autor insere sua crítica no conjunto de forças internacionais que se opõem ao processo de remilitarização da África em curso apontando em seu trabalho a luta, 
segundo ele insensata, entre as potências ocidentais pela disputa dos recursos petrolíferos da região (Campbell, 2012, p.4).

Chamando a atenção ao fato de que a Líbia tinha até então o segundo maior IDH da África, tinha uma economia interna de base distributiva, mas que, no entanto, vivia sob um regime autoritário, o que de fato mobilizou as manifestações de oposição a Kadaffi. No caso do Egito e da Tunísia os protestos foram contra reformas neoliberais, na Líbia, ao contrário, os protestos reivindicaram abertura e adequação ao ocidente e o embate assim foi travado entre "reformadores" e "nacionalistas." Sua análise está fundamentada em ideias emancipatórias se aproximando da perspectiva de Vijay Prashad.

No mesmo sentido que Campbell, Prashad aponta que a revolta na Líbia que tomou ares de "reforma neoliberal" pode em grande medida ser explicada pela questão do petróleo, fundamental para se entender os desdobramentos da Primavera Árabe:

The Atlantic powers made a deal with the Saudits and the Gulf Arab states that allowed the latter to silence dissent on the Arabian Peninsula (Bahrain and Yemen), if they would deliver the Arab League, and thus the United Naitons, for a NATOled intervention in Libya. The spotlight shone on Qatar, which did the leadership work for the Gulf Arabs. Its emir could remarkably draw the shine from the Arab Spring, dent its republicanism and fashion himself as a rebel in Libya, not in Doha. The oil is a central issue with Libya, but so too was its political significance. That the Atlantic states and their Gulf Arab partners decided to intervene in Libya and not in Bahrain or Yemen, and certainly not in Syria, tell us something. (Prashad, 2012, p. 8).

Prashad não pretende apresentar um prognóstico acerca do futuro da Líbia pós-intervenção, mas afirma categoricamente que a Primavera Árabe foi inflada e "insinuada" pelos poderes Atlânticos a fim de criar o "Inverno Líbio" e assim avançar em seus interesses nacionais, nos interesses das empresas multinacionais de petróleo e nas reformas neoliberais dentro da Líbia.

Embora tenham sido apresentadas análises divergentes, todas as perspectivas, favoráveis ou contestatórias, afirmam que de fato os desdobramentos da Primavera Árabe na Líbia devem ser analisados a partir da compreensão dos interesses políticos e econômicos relacionados especialmente a exploração de petróleo na região. Portanto, na seção a seguir serão analisadas as duas principais frentes de atuação do Brasil na Líbia: exploração de petróleo e construção civil. 


\section{3}

\section{O Ouro Negro e as Empreiteiras}

Com a revogação das sanções à Líbia pelo Conselho de Segurança da ONU e referendada pelo Brasil em 2003, o campo para as empresas brasileiras no país norte-africano se mostrou fértil. Nesse ano cerca de 600 brasileiros viviam na Líbia e dentre eles quase $100 \%$ eram funcionário de alguma das três principais empreiteiras brasileiras: Odebrecht, Queiroz Galvão e Andrade Gutierrez ${ }^{33}$.

Pedro Henrique Pedreira Campos (2012) em tese de doutorado apresenta a ação das empreiteiras brasileiras durante a ditadura civil-militar. Em analogia ao texto de Marx, O 18 Brumário de Luís Bonaparte, em que este afirma que os eventos históricos ocorrem duas vezes: a primeira como tragédia e a segunda como farsa, Campos aponta que a atuação das empreiteiras brasileiras no mercado internacional segue o mesmo sentido proposto por Marx.

Na década de 1990 a empresa brasileira Mendes Júnior era a mais internacionalizada entre as empreiteiras possuindo contratos bilionários no Iraque. Com a invasão norte-americana ao país árabe em 1991 a empresa brasileira encerrou suas atividades e retirou funcionários e equipamento do Iraque e logo em seguida ingressou em um processo de dívidas com o governo brasileiro culminando em sua falência.

Em analogia à máxima de Marx, Campos afirma que em 2011 a história se repete agora no contexto dos conflitos na Líbia. A guerra civil entre as forças de Kadaffi e as forças de oposição apoiadas pela OTAN levaram à retirada de empresas brasileiras do território Líbio, a saber: Andrade Gutierrez, Queiroz Galvão e Noberto Odebrecht. Assim como a Mendes Júnior na década de 1990, a Odebrecht, que realizava as obras do anel rodoviário e do aeroporto de Trípoli em 2011, reivindicou ao governo brasileiro o ressarcimento do prejuízo contraído devido a retirada, exigindo 300 milhões de dólares ao BNDES pelas perdas tidas em território líbio. A história se repetiria da mesma forma se não fosse a farsa: a

\footnotetext{
33 ELIZONDO, Gabriel. Aljazeera - Disponível em: http://blogs.aljazeera.com/blog/americas/brazils-business-libya Acessado em 23 de novembro de 2014.
} 
Odebrecht não teve prejuízo significativo comparado à receita anual de 60 bilhões de reais e ainda assim, recorreu às agências estatais para sanar o prejuízo mínimo. (Campos, 2012).

Além da Andrade Gutierrez, Queiros Galvão e Noberto Odebrecht também compõe o grupo de empresas brasileiras que operam na Líbia a Camargo Correa. Cabe ressaltar que bem como em outros países do continente africano a Líbia é terreno de forte disputa de mercado. A concorrentes mais fortes são as empresas chinesas e para entrar na disputa as empresas brasileiras utilizam estratégias de associação para fazer frente ao poderio chinês.

A China se tornou importante parceiro comercial da Líbia enviando uma média de 35.000 cidadãos chineses para trabalharem nas áreas de infraestrutura e telecomunicações, mas não é a única concorrente no país norte-africano. No ano de 2008 o presidente da Rússia Vladimir Putin teria viajado a Líbia acompanhado de 400 assistentes, dentre jornalistas e executivos, para negociar uma dívida de cerca de 4,5 bilhões de dólares da Líbia para com a antiga União Soviética através de contratos de infraestrutura, incluindo estradas de ferro e moradias, além de projetos na área de energia envolvendo a gigante russa, maior exportadora de gás natural do mundo, Gazprom. Em ocasião da visita de Putin à Líbia, Kadaffi manifestou oposição à expansão da OTAN na Ucrânia e Geórgia contrariando o projeto de uma OTAN global (Campbell, p.135, 2012).

Como vimos no capítulo anterior, a presença de empreiteiras brasileiras na Líbia tem sido significativa desde os governos militares no Brasil até os anos mais recentes. No entanto, possivelmente, a questão do petróleo seja fundamental nas relações Brasil e Líbia e no âmbito da Cooperação Sul-Sul é essencial compreender suas nuances e recentes transformações, as mudanças de fluxos e desafios ao status quo da política econômica internacional.

Horace Campbell (2012) aponta que desde 1945 estudiosos de diferentes matizes ideológicas apontavam a centralidade das companhias de petróleo na definição da política externa dos EUA bem como a posição dominante de empresas petrolíferas norte-americanas e britânicas na política econômica internacional.

A crise econômica de 2008 abalou os pilares da hegemonia norte-americana e o despontar de novos atores disputando espaço no sistema internacional inaugurou o cenário de protagonismo das então denominadas potências emergentes. 
Evidentemente, o mercado do petróleo seria uma das principais arenas de disputa onde uma nova reconfiguração do sistema internacional começa a se gestar.

Campbell destaca que a vertiginosa ascensão de petrolíferas Chinesa e Brasileira criou uma nova política econômica internacional. Diante da pujança da Líbia no que tange ao seu potencial na produção de petróleo espaços importantes foram abertos para negociações com companhias petroleiras da China, Brasil e também da Rússia.

By 2011, China had overtaken Japan and Brazil had overtaken Britain in the league of economic powerhouses. Neither Brazil nor China fell under the complete control of the Western energy and financial institutions. Through energetic and skilful negotiations, the political leaders of Brazil, Russia and China had made great strides in negotiating new agreements with the Libyan leadership. (Campbell, 2012, p.135).

De modo mais amplo, sete empresas petrolíferas estatais de sete Estados protagonizam a ascensão de novos atores estatais que contestam e abalam o sistema financeiro internacional, dentre eles apenas um se mantém fortemente alinhado aos interesses "ocidentais":

China's CNPC, Russia's Gazprom, Iran's NIOC, Venezuela's PDVSA, Brazil's Petrobras, Malaysia's Petronas and Saudi Arabia's Aramco - had shaken the international financial system, where new barter arrangements were being made to shelter these states against the vagaries of the US dollar. Among these seven countries there was only one firm ally of the West and the dollar, viz Saudi Arabia. (Campbell, 2012, p. 136).

A Petrobras está presente na Líbia desde a década de 1970, e depois de 11 anos de atividades paralisadas, retoma seus projetos no país norte-africano no ano de 2005, sob o governo Lula. A Líbia é o único país da região do Norte da África onde a Petrobras teve atuação. O projeto iniciado em 2005 foi o terceiro realizado na Líbia. Os dois primeiros foram projetos onshore e este último com estratégia distinta focou a exploração no mar. Em janeiro de 2005 a Petrobras venceu a rodada de licitação da estatal líbia National Oil Corporation adquirindo os direitos exploratórios de óleo e gás e de partilha de produção da Área 18, que corresponde a 4 blocos de 10,307 mil km2 de extensão total. Esta é uma área situada ao noroeste da costa líbia, no Mar Mediterrâneo, tendo uma variação de 200 a 700 metros de profundidade. Sendo operadora do consórcio a Petrobras detém $70 \%$ de 
participação ${ }^{34}$. Em certa medida, a inserção da estatal brasileira na Líbia também pode ser explicada pela diversificação da matriz energética nos EUA que tem investido na exploração do xisto, rico em seu território, o que abriria espaço para a inserção de outros atores na região ${ }^{35}$.

Em fevereiro de 2011 as empresas brasileiras presentes na Líbia, dentre elas a Petrobras, e o Itamaraty confirmam ter retirado seus funcionários do território líbio em razão do agravamento dos conflitos ${ }^{36}$. Ainda nesse ano o então presidente da Petrobras José Sérgio Gabrielli apontou que o retorno da petrolífera brasileira à Líbia dependeria do curso que a transição política tomaria ${ }^{37}$

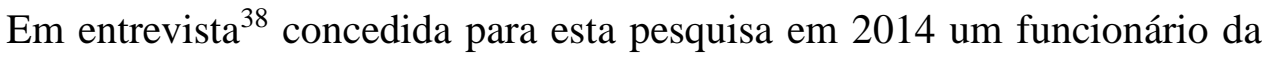
Petrobras que serviu na Líbia durante o último projeto afirmou que devido ao conflito foi acionada a cláusula de força maior do contrato suspendendo as atividades, mas no entanto, os projetos de campo já haviam sido concluídos. Atualmente não existem mais funcionários da Petrobras brasileiros expatriados na Líbia. Além disso, o entrevistado afirmou que:

As perspectivas de futuras atividades da Petrobras na Líbia estão ligadas exclusivamente a disponibilidade de projetos naquele país que se coadunem com as premissas do Planejamento Estratégico da Petrobras. Nesse momento, vemos como pouco provável o desenvolvimento de novos negócios naquele país, muito embora não se possa descartar completamente esta possibilidade ${ }^{39}$.

\footnotetext{
${ }^{34}$ PETROBRAS - Disponível em: http://www.petrobras.com/pt/paises/libia/libia.htm Acessado em 21 de julho de 2014.
}

${ }^{35}$ MARIN, Denise Estadão Disponível em: http://economia.estadao.com.br/noticias/economiageral,exploracao-de-gas-de-xisto-nos-estados-unidos-inicia-revolucao-energetica, 160917,0.htm Acessado em 06 de fevereiro de 2014.

${ }^{36}$ Senado Notícias - $\quad$ Disponível em: http://www2.senado.leg.br/bdsf/bitstream/handle/id/48724/noticia.htm?sequence=1 Acessado em: 08 de janeiro de 2015.

37 LAESSING, Ulf, AL-WARFALLI, Ayman e BOSALUM, Feras - Reuters Diponível em: http://br.reuters.com/article/businessNews/idBRSPEA3501I20140406 Acessado em: 08 de janeiro de 2015 .

${ }^{38}$ Foram também solicitadas entrevistas a representantes do Ministério da Saúde; da FioCruz; das emrpesas Odebrecht, Queiroz Galvão, Andrade Gutierrez e Camargo Correa; de funcionários líbios da Petrobras que trabalharam na unidade da estatal brasileira na Líbia; e do deputado estadual Adrian Mussi, líder da comissão parlamentar enviada à Líbia em 2011. No entanto, não obtivemos resposta.

${ }^{39}$ Entrevista concedida por funcionário da Petrobras que atuou na Líbia no último projeto. Realizada em 30 de outubro de 2014 
Além disso, o entrevistado apontou que a atuação da Petrobras na Líbia ocorreu de forma autônoma em relação à embaixada brasileira. Apesar de haver apoio desta, ressaltando o apoio na transferência de funcionários brasileiros tanto da Petrobras quanto das empreiteiras no contexto de agravamento dos conflitos, é possível inferir que não há uma relação fortemente articulada entre embaixada e as empresas brasileiras na Líbia. A atuação das empresas nesse sentido exerce um papel de vanguarda abrindo os espaços de cooperação entre os dois países.

Com os projetos encerrados ou interrompidos devido aos conflitos e subsequente retirada de funcionários brasileiros expatriados na Líbia, a situação atual é bastante complexa. Recentemente, em abril de 2014, em um ambiente ainda politicamente instável, o governo líbio negociou com as forças de oposição a abertura de dois portos petrolíferos que haviam permanecido 8 meses fechados devido aos $\operatorname{conflitos}^{40}$. Na seção a seguir serão analisados os movimentos do governo brasileiro sob a gestão Dilma de reabertura de espaços no contexto pós Kadaffi para a atuação de empresas brasileiras na Líbia.

\section{4}

\section{O Governo Dilma e a Era pós-Kadaffi}

Os conflitos travados na Líbia no contexto da Primavera Árabe e a subsequente intervenção da OTAN são marcos que revelam um ponto de inflexão das relações entre Brasil e Líbia especialmente porque no mesmo ano, a presidente do Brasil Dilma Rouseff inicia seu mandato e imediatamente a questão da Líbia se torna uma pauta urgente na agenda da política externa brasileira.

Há importantes questões que diferenciam as relações Brasil-Líbia entre os governos Lula e Dilma. Em primeiro lugar, as próprias distinções da condução da política externa brasileira entre os dois governos. Além disso, em segundo lugar, mas intimamente ligada à primeira questão, está o posicionamento do governo

${ }^{40}$ REUTERS - Disponível em: http://br.reuters.com/article/topNews/idBRSPE77M0SF20110823 Acessado em: 08 de janeiro de 2015. 
brasileiro sob o mandato de Dilma a respeito dos desdobramentos da Primavera Árabe e, em especial, no caso da Líbia o contexto de intervenção da OTAN e os debates da Responsabilidade ao Proteger.

No primeiro aspecto, cabe ressaltar o compromisso de Dilma em dar destaque à agenda de defesa dos direitos humanos e em, especial, aos direitos das mulheres em seu mandato, muito embora tal compromisso não tenha sido efetivamente cumprido. O que é evidentemente uma demanda internacional requisito fundamental para levar a cabo o objetivo de evidenciar o Brasil enquanto Global Player. Nesse sentido, a aproximação com os países árabes, em geral caracterizados por regimes ditatoriais que ferem uma série de direitos humanos aos moldes ocidentais, mais uma vez com especial destaque os direitos das mulheres torna-se uma problemática.

O questionamento de Paul Amar (2014) reflete esta inflexão: Como Dilma, primeira mulher eleita no Brasil, e seu discurso de empoderamento da mulher, poderia manter as relações intensificadas durante o governo Lula entre o Brasil e os países árabes? Como lidar com esse estreitamento diante dos simultâneos eventos da Primavera Árabe? (Amar, 2014).

Para Amar, Lula compreendia as aproximações com os países árabes e, em especial com a ASPA, de forma instrumentalizada para solidificar mecanismo de cooperação Sul-Sul que desafiassem o status quo e ao mesmo tempo elevasse o Brasil como um mediador nas relações Norte-Sul:

Previously, during Lula's eight-year term Brazil had been instrumental in forming a diplomatic bloc, ASPA (the Summit of South America-Arab States) that had became a key instrumento of South-Souht economic and cultural cooperation and an incubator for cultivating geopolitical resistance to what Brazilians reter to as the "paternalistc mediation" of nothern and western governments in the affairs of the Global South or the postcolonial east." (Ibid., p. 18).

A linha tênue entre atender às demandas internacionais fortemente vinculadas a valores ocidentais e ao mesmo tempo solidificar as relações Sul-Sul também foi um desafio para Lula, não só para Dilma: como justificar domesticamente e internacionalmente o relacionamento com a Líbia sendo o Brasil um ator com intentos cada vez maiores de se inserir no sistema internacional enquanto que a Líbia tendia a se isolar dele? Principalmente diante de movimentos à esquerda na América Latina no final de 1990 e início dos anos 2000, conhecido 
como "pink tide”. O que se tornou um desafio para a recém criada ASPA, em 2005. Como manter a solidariedade e cooperação com países árabes marcados por regimes ditatoriais, monarquias autoritárias e com diversos problemas relativos aos direitos humanos os quais são veementemente reivindicados pelos movimentos políticos da América Latina?

Under president Lula, Brazil had asserted itself as a leader of emerging Global South powers and an articulator of new forms of South-South cooperation. But while doing so, Brazil walked a fine line between two conflicting aspirations. On the on hand Brazil wanted to convince northern powers, particularly the United States and Europe, that South America's superpower was ready to provide "mature" world leadership and would act as a stabilizing force in global affairs. By impressing northern powers, Brazil aimed to prove itself worthly of being named the sixth permanente member of the United Nations Security Council (Amar 2013; Neto 2013) On the other hand, by reaching out to the Middle East in ways that deployed rival visions to Western geopolitical and policy approaches to the region, Brazil explicitly challenged the hegemony of those very powers with whom it was try to win favor. With this more counterhegemonic project in mind, Lula revived the Third Worldist language of the Non-Aligned Movement of the 1950s and 1960s and of the bandung conference (Ibid.).

Não obstante as duas fortes aspirações conflitantes, Amar aponta que ainda assim Lula pareceu incorporar mais o espírito contra-hegemônico terceiro mundista que Dilma, pois em sua gestão o Brasil adota mais uma postura pragmática do que a de manter o ideal da conferência de Bandung (Amar, 2014).

She would confront contradictions between Brazil's democratic political goals and its global realpolitik aspirations, first with the "betrayal" by the United States of Brazil's good-faith efforts to negotiate an accord with Iran over the development of nuclear technology, and then more dramatically, as the United States, France, and NATO mobilized for armed intervention in Libya and then Syria (Amar, 2014, p. 25).

Nesse sentido, Casarões (2014) aponta reação interna contrária ao caso particular da aproximação do Brasil com a Líbia durante o governo Lula evidenciada marcadamente nos veículos da imprensa:

Esse movimento, por outro lado, causou grande desconforto em alguns setores domésticos e repercutiu até mesmo na mídia internacional. Diante da visita de Lula aos líderes da região, na qual sobressaiu o encontro com Kadafi, o jornal britânico Financial Times salientou o caráter político da aproximação, entendida como uma provocação aos Estados Unidos. A revista Veja rotulou a diplomacia presidencial de "a turnê de Lula pelas ditaduras", chamando a política externa daquele governo de "insignificante, quando não grotesca" Outro veículo influente, a Folha de São 
Paulo, publicou editorial, a mesma época, condenando a "diplomacia de resultados" de Lula por "atropelar" direitos humanos, nas relações com os autocratas do mundo árabe. Naquela oportunidade, o chanceler brasileiro, Celso Amorim, reiterou que a visita presidencial não seria ideológica, mas de negócios, buscando explorar oportunidades comerciais nas áreas de maquinário agricola, aviação e construção civil. (Casarões, 2014, p.47).

Amar avança ao apontar que a principal diferença entre a política externa brasileira para os países árabes durante os governos Lula e Dilma é acerca dos direitos humanos. Por um lado está a política externa personalista de Lula que apertou a mão de Kadaffi e Ahmedinejad. E por outro o compromisso de Dilma, a primeira mulher a fazer o discurso de abertura da sessão da Assembleia geral da ONU, com questões referentes aos direitos humanos, empoderamento das mulheres e etc. (Amar, 2014).

Os padrões de votação no Conselho de Segurança da ONU apontam também esta distinção. A participação do Brasil no CS enquanto membro não permanente (com direito a voto, mas não a veto) o país acaba de totalizar 10 mandatos: 194647; 1951-52; 1954-55; 1963-64; 1967-68; 1988-89; 1993-94;1998-99; 2004-05 e 2010-11. Em sua atuação destaca-se, formalmente, a defesa dos princípios tradicionais da Política Externa Brasileira: defesa da paz e da segurança (nesta incluída a solução pacífica de controvérsias); respeito a integridade territorial soberana; defesa do multilateralismo e do direito internacional. No que se refere à sua contribuição mais prática, o Brasil tem papel proativo, desde a fundação da Organização, nas operações de paz. (Ferreira, 2012, p.2).

Nesse sentido, os votos do Brasil no CS durante os dois mandatos do presidente Lula foram favoráveis aos países do Oriente Médio quando sanções a estes estavam em pauta ${ }^{41}$. Na gestão de Dilma Rousseff o objetivo de dar maior centralidade a questões relacionadas aos direitos humanos gera mais um ponto de inflexão. Em 2011 o Brasil votou a favor do Conselho de Direitos Humanos para enviar relator da ONU para a proteção dos direitos individuais no Irã, mostrando o novo compromisso com os direitos humanos adotado pelo governo Dilma:

O Irã acusou o governo de Dilma Rousseff a dobrar "para pressionar os Estados Unidos e insinuou traição." É realmente lamentável ver o Brasil tomar esta

\footnotetext{
${ }^{41}$ Palestra proferida pelo professor Guilherme Casarões no seminário "Tentativas de Mediação Brasileira no Oriente Médio: uma avaliação". Fundação Getúlio Vargas em 01 de novembro de 2013.
} 
posição", disse o embaixador do Irã na ONU, Sayad Sajjadi. Teerã esperava uma abstenção, repetindo o padrão de votação durante o governo Lula ${ }^{42}$.

No caso da Síria em 2011 o Brasil se absteve de votar, alinhado com os países do IBAS (Índia, Brasil e África do Sul) e Líbano, a resolução S/2011/612 condenando a Síria por violações dos direitos humanos. O projeto recebeu o veto da Rússia e da China. (Ibid. p.4). Até então, a postura brasileira manteve-se de acordo com o posicionamento favorável aos países árabes no que tange às sanções. No entanto, em 03 de agosto de 2012 o voto do Brasil na Assembleia Geral da ONU foi a favor da Resolução $66 / 253 / b^{43}$ apontando com grande preocupação as crescentes violações dos direitos humanos no conflito sírio, distanciando postura BRICS (Benner, 2013). Mais uma vez, o Brasil está em um ponto de inflexão na tentativa de equilibrar a defesa da soberania com a agenda de direitos humanos.

Como apontado inicialmente, tal diferença na orientação da política externa brasileira entre os governos Lula e Dilma está intimamente ligada ao segundo aspecto que é a discussão fundamental que marca o ponto de inflexão dos dois governos, tanto cronologicamente, pois se dá exatamente no período de transição de um governo para o outro, quanto no plano de orientação da PEB acerca dos direitos humanos: a Responsabilidade de Proteger (R2P).

No caso específico da Líbia é emblemática a discussão acerca do princípio da Responsabilidade de Proteger por este ter sido utilizado como legitimador de uma ação da OTAN pela primeira vez e ter sido alvo de muitas críticas.

Formulada em 2001 a Responsabilidade de Proteger viabiliza a intervenção com uso da força em casos em que um determinado estado não exerce plenamente sua soberania violando direitos humanos fundamentais de seus civis. Nesse sentido, possibilita a ação da comunidade internacional sem que haja impedimento pelo veto de um dos membros do Conselho de Segurança da ONU prevendo assim a suspensão do princípio de não ingerência em assuntos internos.

Diante dos conflitos travados na Líbia o Conselho de Segurança da ONU considerou que Kadaffi cometia sérias violações aos direitos humanos e fazia o uso

\footnotetext{
${ }^{42}$ JUSBRASIL Disponível em $\quad$ :http://congresso-emfoco.jusbrasil.com.br/politica/6771004/manchetes-dos-jornais-dilma-modifica-politica-de-lula-evota-contra-o-ira Acessado em: 03 de dezembro de 2013.

43 GLOBAL R2P - Disponível em :http://www.globalr2p.org/media/files/ungasyriaaug3.pdf Accessado em: 02 de novembro de 2013.
} 
da força contra civis, incluindo seus opositores, e aprovou em fevereiro de 2011 a Resolução $1970^{44}$ decretando sanções como o embargo de armas. Sem resultados imediatos, em março de 2011 é aprovada a Resolução $1973^{45}$ determinando a intervenção na Líbia, sob capítulo VII da Carta das Nações Unidas e, portanto, com o uso da força diante da recusa ao consentimento e recorrendo pela primeira vez ao princípio da Responsabilidade de Proteger.

O Brasil se abstém do voto no Conselho de Segurança da ONU referente à Resolução 1973 que autoriza a ação que, por sua vez, foi muito criticada em seus resultados, tendo o Brasil como um dos atores críticos. A "Responsabilidade de Proteger", substituta do "direito de ingerência" tem três princípios fundamentais: responsabilidade de reagir, responsabilidade de prevenir, responsabilidade de reconstruir. Assumindo tais responsabilidades a ação com uso da força, sob capítulo VII da Carta das Nações Unidas pode ser deflagrada. (Jubilut, 2007).

O governo brasileiro manteve-se, assim, alinhado ao posicionamento dos demais países do BRICS e endossando o discurso dos países do Sul Global. Em declaração na 66 Assembleia Geral da ONU em setembro de 2011 Dilma Rousseff se opõe claramente à R2P propondo um avanço na concepção do princípio:

\begin{abstract}
Nossa postura frente aos acontecimentos políticos recentes no Oriente Médio e no norte da África é prova disso. Muito se fala sobre a responsabilidade de proteger; pouco se fala sobre a responsabilidade ao proteger. Esta responsabilidade ao proteger foi objeto das iniciativas da África do Sul, da Índia e do Brasil dentro do Conselho de Segurança da $\mathrm{ONU}^{46}$.
\end{abstract}

O Brasil, então, torna-se porta-voz de um novo conceito: Responsabilidade ao Proteger (Responsability While Protecting - RwP), criticando não os princípios

\footnotetext{
${ }^{44} \mathrm{CSNU} \quad$-Disponível

http://www.nato.int/nato_static/assets/pdf/pdf_2011_02/20110927_110226-UNSCR-1970.pdf

Acessado em: 16 de outubro de 2013.

${ }^{45} \mathrm{CSNU} \quad \mathrm{http} / / / \mathrm{www}$. nato.int/nato_static/assets/pdf/pdf_2011_03/20110927_110311-UNSCR1973.pdf Acessado em: 16 de outubro de 2013.

${ }^{46} \mathrm{MRE}$ - Minitério das Relações Exteriores - Presidente da Repúlbica FEdderativa do Brasil Discursos. http://www.itamaraty.gov.br/index.php?option=com_content\&view=article\&id=4650:discurso-dapresidenta-da-republica-dilma-rousseff-durante-reuniao-plenaria-da-v-cupula-do-ibas-pretoriaafrica-do-sul-18-10-2011\&catid=197\&Itemid=448\&lang=pt-br Acessado em 18 de outubro de 2013.
} 
da R2P, mas sua implementação, apontando a necessidade de esgotar todos os recursos antes do uso da força evitando o agravamento dos conflitos.

O princípio da "Responsabilidade ao Proteger" fundamenta-se em tais bases: a valorização da prevenção e dos meios pacíficos de solução de controvérsias; a necessidade de exaurir todos os meios não-violentos para a proteção de civis; a obrigação de que qualquer ação militar seja sempre autorizada pelo Conselho de Segurança, limitada em seus elementos operacional e temporal; e a necessidade de monitoramento e avaliação da implementação das resoluções que autorizem intervenções ${ }^{47}$.

O conceito não foi levado adiante devido à falta de apoio tanto das potências ocidentais quanto da China e Rússia como explicitado no primeiro capítulo. (Benner, 2013) No entanto, pode ser observada, evidentemente, a ênfase na prevenção de conflitos em detrimento da ação com uso da força, evidenciando a postura tradicional de defesa da soberania estatal/territorial da política externa brasileira e, ao mesmo tempo, um esforço no sentindo de se estabelecer enquanto agente normativo, ou empreendedor de normas no cenário internacional.

Com a agenda cada vez mais voltada para preocupações pertinentes aos direitos humanos, o governo brasileiro adota uma postura de defensor do direito individual e das questões humanitárias.

Se, como apontou Amar, por um lado Lula conduzia a política externa de forma mais personalística e contra-hegemômica enquanto que Dilma teve uma preocupação maior em atender as demandas relacionadas aos direitos humanos, há de se destacar os interesses despolitizados pelo discurso da Responsabilidade ao Proteger defendido por Dilma. Como o próprio Amar apontou, o bom relacionamento de Lula com Kadaffi que permitiu o empreendimento de muito negócios entre Brasil e Líbia poderia ser um fator negativo para o Conselho Nacional de Transição (CNT) o que impediria a continuidade dos projetos brasileiros no país norte-africano pós-Kadaffi:

The new prime minister of Libya, Abdurrahim al-Keib, said that the Libyan government would 'explore whether the contracts signed [by Gaddafi] previously prioritized price or personal relationship with the brazilian government' (Brazilian

47 MRE - Disponível em: http://www.itamaraty.gov.br/sala-de-imprensa/notas-aimprensa/participacao-do-ministro-das-relacoes-exteriores-antonio-de-aguiar-patriota-em-debatesobre-responsabilidade-ao proteger-na-onu-2013-nova-york-21-de-fevereiro-de-2012/print-nota Acessado em 04 de julho de 2014. 
Bubble 2012) means that Lula's personalized support for the old regime would be sanctioned, pos facto. (Amar, 2014, p. 26)

Ao mesmo tempo em Dilma se pronunciava a favor da soberania e de repensar o princípio da Responsabilidade de Proteger ela buscou manter os laços com a Líbia no período pós Kadaffi preparando o terreno para garantir os interesses do Brasil na região. No próprio histórico das relações Brasil e Líbia no site do Itamaraty aponta esse movimento de (re)aproximação após intervenção:

O conflito líbio iniciado em 2011 afetou novamente as relações bilaterais. A visita à Líbia do Subsecretário-Geral Político III do Ministério das Relações Exteriores, ainda em 2011, deu início a novo processo de reaproximação. Em 2012, o VicePrimeiro-Ministro líbio, Omar Abdelkarim, visitou o Brasil. A Embaixada brasileira em Trípoli foi reaberta em junho de 2012. A Líbia é um dos principais destinos de investimentos brasileiros no continente africano. Há interesse líbio em cooperação com o Brasil na área de investimentos, em intercâmbio de experiências para a transição democrática, capacitação de agentes públicos e de segurança ${ }^{48}$.

Imediatamente após a morte de Kadaffi, a Líbia passa a ser um campo fértil de oportunidades para a inserção de empresas principalmente europeias e asiáticas. ${ }^{49}$ Em 2012 o Ministério de Desenvolvimento, Indústria e Comércio Exterior (MDIC) do Brasil indicou a organização de uma missão empresarial brasileira à Líbia para identificar oportunidades de investimentos e negócios para empresas brasileiras no país africano ${ }^{50}$.

Ainda em 2012 a presidente brasileira propôs enviar especialistas para auxiliarem nas eleições parlamentares na Líbia, além de enviar técnicos para identificação de armas e medicamento para auxílio ao combate à $\operatorname{AIDS}^{51}$.

${ }^{48} \mathrm{MRE}$ - Ministério das Relações Exteriores - Itamaraty Disponível em: http://www.itamaraty.gov.br/index.php?option=com_content $\&$ view=article \&id=5379\&Itemid=47 8\&cod_pais=LBY\&tipo=ficha_pais\&lang=pt-br Acessado em: 03 de fevereiro de 2015.

49 SHANE, Scott. The New York Times Disponível em: http://www1.folha.uol.com.br/fsp/newyorktimes/ny1011201105.htm Acessado em 04 de julho de 2014.

${ }^{50} \mathrm{MDIC}-$ Ministério do Desenvolvimento, Indústria e Comércio Exterior. Disponívelem:http://www.amazonia.mdic.gov.br/portalmdic/////sitio/interna/noticia.php?area=1\&n oticia=11474 Acessado em 15 de junho de 2014.

${ }^{51}$ ANBA Agência de Notícias Brasil-Árabe. Disponível em: http://www.anba.com.br/noticia/13387428/diplomacia/brasil-ajudara-libia-nareconstrucao/?indice=200 Acessado em 16 de outubro de 2013. 
Em 2013 através do convite do deputado brasileiro Adrian Mussi o ministro do Petróleo e Gás da Líbia Abdulbari Al Arousi visitou o Brasil e declarou o interesse por parte do novo governo líbio em firmar parcerias com o Brasil especialmente na área de energia e construção civil ${ }^{52}$.

A presidente Dilma também reforçou os laços do Brasil com os países da Liga Árabe. Em 09 de março de 2014 o embaixador do Brasil no Egito, Marco Antônio Brandão, foi credenciado como Representante Especial do Brasil junto à Liga dos Estados Árabes. Essa é a primeira vez que o Brasil tem um representante oficial junto ao bloco árabe ${ }^{53}$.

É portanto evidenciado esforço do governo brasileiro no sentido de encontrar possiblidades e manter espaços abertos tanto na Líbia quanto em outros países da região após os desdobramentos da Primavera Árabe. É fundamental, nesse sentido, compreender minimamente o contexto líbio pós-intervenção da OTAN.

Logo após a morte de Kadaffi foi iniciado um processo de transição na Líbia em moldes democráticos, sendo a França o primeiro país a reconhecer o Conselho Nacional de Transição (CNT):

The Temporalaly Constitutional Declaration for the Transitional Stage, released on 3 August 201, outlined a 13 - month process leading to a general elections and the formationa of a new government. With the release of the draft elections law on 8 February 2012, the process outlined in the Delcaration was already four months behind schedule, and the timetable latter slipped further still. Follwing the General National Congress (GNC) elections, the NTC dissolved itself and handend over power to the GNC on 8 August 2012. The GNC then appointed a prime minister to form a new interim government to rule until a new constitution is approved and general elections are held somtime in 2013. (St John, 2014, p. 101).

No entanto tal processo não foi consolidado. Em março de 2014 foi levado a debate propostas de restauração da monarquia na Líbia. Os mais recentes relatos dão conta de que o ambiente político é extremamente instável, e ainda bastante

${ }^{52} \mathrm{LUZ}$ DA, Natalia. Por dentro da África - Disponível em: http://www.pordentrodaafrica.com/negocios/queremos-desenvolver-uma-parceria-importantecom-o-brasil-diz-ministro-do-petroleo-da-libia Acessado em 13 de janeiro de 2015.

53 MRE - Ministério das Relações Exteriores do Brasil - Itamaraty. Disponível em: http://diplomaciapublica.itamaraty.gov.br/63-representante-especial-do-brasil-e-acreditado-juntoa-liga-dos-estados-arabes. Acessado em: 03 de novembro de 2014. 
violento expondo os conflitos étnicos e regionais históricos ${ }^{54}$. Devido à insegurança, em julho de 2014 o Itamaraty transferiu a embaixada brasileira da Líbia para a Tunísia 55 .

Embora o ambiente na Líbia atual seja bastante complexo, parece ser ainda um campo fértil para investimentos. Alguns autores fizeram análises recentes indicando tentativas de projeções, possibilidades, continuidades e descontinuidades.

Youssef Mohammed Sawani (2013), professor de Relações Internacionais na Universidade de Trípoli ${ }^{56}$, aponta que a morte de Kadaffi se deu pelas mãos de seu próprio povo, apesar de ter sido também consequência da intervenção da OTAN com apoio de alguns países árabes. Para o autor a história contemporânea da Líbia tem sido guiada por quatro "dinâmicas perpétuas": religião, tribalismo, regionalismo e petróleo. Tais dinâmicas, segundo o autor, se perpetuam mesmo no atual período de transição. E o petróleo foi e continuará sendo o ingrediente essencial do processo de transformação política, econômica e social da Líbia.

Segundo Ronald St John (2014), para que o governo de transição opere mudanças econômicas significativas aos moldes neoliberais com diversificação e abertura da economia, paradoxalmente irá precisar de um estado forte e interventor que trabalhe com o que ficou do governo Kadaffi e seu recente movimento de abertura. Nesse caso, os investimentos externos serão bem-vindos e em longo prazo a economia política pós Kadaffi provavelmente será um mix de um estado forte nos esforços de reconstrução e serviços de bem-estar social com orientação de mercado no processo de reforma econômica. Quanto ao petróleo, John aponta que em 2012 a produção de petróleo atingiu os níveis pré-revolução, mas no entanto a insegurança afastou as empresas petroleiras da região.

\footnotetext{
${ }^{54}$ GATESTONE INSTITUTE Disponível em: http://www.gatestoneinstitute.org/4251/libyamonarchy Acessado em: 13 de janeiro de 2015.

${ }^{55}$ EBC Agência Brasil- Disponível em: http://agenciabrasil.ebc.com.br/internacional/noticia/201407/itamaraty-transfere-embaixada-da-libia-para-tunisia-por-falta-de Acessado em: 13 de janeiro de 2015.

${ }^{56}$ Cabe ressaltar sua atuação como Diretor Executivo da Gadaffi International Charity and Development Foudantion Disponível em: http://www.gaddaficharity.org/ Acessado em 13 de janeiro de 2015.
} 
Ainda Christopher S. Chivvis, Keith Crane, Peter Mandaville, Jeffrey Martini (2012) destacam os desafios de segurança e também os desafios econômicos da transição na Líbia com foco no seu principal recurso, o energético: "Libya needs to begin rethinking the manegement of its economy, and especially of its energy resources, in order to maximize the benefit to its citizens, reduce corruption, and enable private enterprise to flourish in other areas, such as tourism”. (Chivvis et al, 2012 p. 1).

Muzzafer Ercan Yilmaz (2012) vai mais além ao prescrever os passos para um processo de construção da paz (peacebuilding) bem sucedido na Líbia. O autor aponta que uma "boa estratégia" para que o sucesso na transformação política que levará a Líbia a ser um país democrático seja menos dolorido envolveria basicamente a justiça transicional, formação de um governo representativo, reforço da segurança, a elaboração de nova constituição, reconstrução econômica e reconciliação nacional. Nessa ordem. (Yilmaz, 2012, p. 47).

Todas essas abordagens remetem a ideia de reconstrução baseada em valores liberais presentes nos modelos e concepções de peacebuilding apresentados no primeiro capítulo. Observar que o Brasil tem buscado se inserir nesse contexto pós Kadaffi e portanto, de "reconstrução" nos remete à questão central desta dissertação Em que medida a cooperação para o desenvolvimento oferecida à Líbia pelo Brasil corresponde ao discurso oficial da diplomacia brasileira no que diz respeito às intervenções humanitárias?

$\mathrm{Na}$ próxima seção será feito um esforço no sentido de buscar se não responder à questão, ao menos compreender como o Brasil articula no discurso e na prática o nexo desenvolvimento-segurança.

\section{5}

\section{O Brasil e o Nexo no Caso da Cooperação com a Líbia}

O discurso brasileiro tradicionalmente tem sido o de crítica ao intervencionismo dos países do Norte Global e, portanto, propõe relações horizontalizadas entre os países do Sul Global, a defesa da soberania e a não intervenção. O paradigma brasileiro de peacebuilding e peacekeeping é emblemático para essa discussão. Segundo Kai Kenkel: 
A política externa brasileira atualmente está vivendo uma transição, de uma cultura regional de segurança que interpreta de maneira restrita a não-intervenção rumo a uma postura com horizonte global que crescentemente a confronta com a necessidade de projetar responsabilidade pela segurança internacional, inclusive por meio de operações de paz robustas. (KENKEL, 2013, p.1)

Em um sentido mais amplo, portanto, é possível observar um ponto de inflexão entre um discurso de crítica ao ocidente (que fomenta a postura de não intervenção) e uma ação no cenário internacional na área de segurança que o impulsiona a uma postura mais intervencionista. Essa inflexão aparece como pano de fundo nas divergências quanto à participação do Brasil no Haiti, se sua ação foi baseada no capítulo VI ou VII da Carta das Nações Unidas ${ }^{57}$, onde a grande questão gira em torno do uso da força e os princípios de soberania e não- intervenção.

No que tange ao aspecto social a proposta brasileira de construção da paz tem uma perspectiva de ação holística visando à cooperação para o desenvolvimento se distanciando, a princípio, da imposição de um modelo liberal econômico.

A participação do Brasil na MINUSTAH marca o momento de transição apontado por Kenkel onde a política externa brasileira deixa de ter apenas o foco na liderança regional para adotar ações de inserção no cenário global mais amplo, pois liderar a missão representa uma aproximação com a ONU no que tange aos intentos claros do Brasil de alcançar um assento permanente no Conselho de Segurança e uma postura de compromisso com a segurança internacional.

Apesar da tensão estabelecida entre defesa da soberania e dos direitos humanos no Haiti, observamos a postura brasileira de dar ênfase ao aspecto do desenvolvimento frente ao intervencionismo por uso da força observada na fala do então Ministro das Relações Exteriores do Brasil, Celso Amorim:

O compromisso do Brasil com o Haiti é firme, amplo e de longo prazo. Ao auxiliar o Governo e o povo haitianos a encontrarem o caminho para o desenvolvimento autônomo e sustentável, o Brasil reforça sua opção pela política externa de nãoindiferença, que conjuga solidariedade e pleno respeito à soberania. Em 2004, o Governo brasileiro respondeu prontamente ao chamado das Nações Unidas para integrar os esforços da comunidade internacional para estabilizar o país. Em paralelo ao exercício do comando da Missão das Nações Unidas para Estabilização do Haiti (MINUSTAH), o Brasil engajou-se em um abrangente programa de

57 ONU - Organização das Nações Unidas - UNICEF - Brasil. Disponível em: http://www.unicef.org/brazil/pt/resources_10134.htm Acessado em:05 de novembro de 2013. 
cooperação, em linha com a posição de que as dimensões de segurança, desenvolvimento e consolidação institucional devem ser abordadas de maneira integrada ${ }^{58}$.

Como observado no primeiro capítulo é importante destacar a noção de "política externa de não-indiferença" na fala de Celso Amorim. A ideia de "nãoindiferença" visa conjugar a defesa da soberania e a observância e sensibilidade à violação dos direitos humanos. Nesse sentido, pode se configurar como um discurso estratégico que objetiva conciliar a defesa da soberania estatal com a com a defesa dos direitos humanos

Em consonância com o Itamaraty, a política externa empreendida durante o governo Lula esteve sempre firmemente focada na defesa da soberania e da não intervenção mantendo sua postura histórica que se refletia em seu padrão de votação enquanto membro não permanente no Conselho de Segurança da ONU. É importante destacar que, para manter a coerência de tal discurso jamais foi admitido pelo Itamaraty que a ação no Haiti tenha sido operada sob o capítulo VII da Carta das Nações Unidas e, portanto, com uso da força.

Esse caso mais uma vez reflete uma espécie de "flexibilização" da política externa brasileira ao longo do governo PT, o que não significa um total aceite da proposta da "Paz Liberal", mas sim estar mais "sensível” à questão humanitária. Como vimos anteriormente, o conceito da "não-indiferença" que legitimaria a participação brasileira e seu protagonismo na MINUSTAH reflete o novo reordenamento do cenário internacional e os esforços do Brasil de se estabelecer enquanto "global player" haja vista a reivindicação por um assento permanente no Conselho de Segurança da ONU pelo governo brasileiro e o uso estratégico dos esforços empreendidos na MINUSTAH para essa finalidade. Ao observar o padrão de votação do Brasil no Conselho de Segurança da ONU é possível constatar também importante mudança de posicionamento entre o governo Lula e o governo Dilma como apresentado na seção “Governo Dilma e a Era pós Kadaffi” em que a presidente petista se apresenta com maior preocupação em atender a agenda de direitos humanos, uma demanda internacional cada vez mais presente.

Nos debates acerca da Responsabilidade de Proteger o posicionamento brasileiro caracterizou-se pelo discurso em que a prevenção de conflitos deve ser

\footnotetext{
${ }^{58}$ AMORIM, Celso In.: Brasil-Haiti - Programa de Cooperação Sul-Sul
} 
enfatizada em detrimento da intervenção pelo uso da força. Observamos, portanto, esforços no sentido de "desecuritizar" a agenda do desenvolvimento, potencializando suas possibilidades de agência no cenário internacional. Nesse sentido, são observados esforços de estabelecimento de agência normativa nos debates de segurança com ênfase na prevenção de conflitos, muito claros no ensaio do RwP.

Para além da retórica humanitária e toda a problemática da intervenção da OTAN na Líbia as fontes documentais aqui apresentadas revelam uma aproximação do governo brasileiro com o governo da Líbia, que se inicia na década de 1970 e se aprofunda no governo PT. São observados interesses políticos e econômicos evidenciados pelo engajamento brasileiro na Líbia por meio de projetos de cooperação técnica e principalmente através de grandes empresas públicas e privadas, especialmente na área de infraestrutura e petróleo.

As recentes relações entre o Brasil e a Líbia e toda a problemática da Responsabilidade ao Proteger são emblemáticas acerca do tema. Ao criticar a implementação do R2P na Líbia propondo a RwP, por um lado, o Brasil se posiciona em defesa da soberania e evidentemente da liderança política com a qual teve bom relacionamento desde longa data. Por outro lado, após a intervenção o Brasil costura laços com o regime de transição apresentando uma postura mais pragmática do que ideológica.

Embora na prática seja uma tarefa complexa mapear e definir as relações estabelecidas no âmbito da Cooperação Sul-Sul em geral devido em grande medida à falta de institucionalização dos canais de cooperação, e comparando com a cooperação brasileira na África subsaariana no caso da Líbia a institucionalização é ainda menor, é possível localizar as relações Brasil e Líbia no âmbito da Cooperação Sul-Sul, como apontado anteriormente em discursos governamentais inclusive.

Além disso, é evidente os interesses econômicos do Brasil na Líbia despolitizados pelo discurso humanitário da Responsabilidade ao Proteger (RwP). A tendência no discurso brasileiro é tender sempre mais ao desenvolvimento do que à segurança, hesitando no movimento de securitizar a agenda de desenvolvimento. Segundo Kenkel ${ }^{59}$ o Brasil tem uma margem grande de ação no campo de

\footnotetext{
${ }^{59}$ Em palestra no Seminário da Associação Brasileira de Relações Internacionais em agosto de 2014
} em João Pessoa PB. 
desenvolvimento configurando um importante instrumento de soft power, mas não introduz esse elemento na agenda de segurança, onde sua margem de ação é menor.

Embora não haja um movimento de intervenção externa institucional para processo de peacebuilding na Líbia, é importante evidenciar os movimentos que o Brasil vem realizando após a morte de Kadaffi visando manter as portas abertas para o mercado do petróleo e das empreiteiras. Nesse sentido, é estratégico o interesse brasileiro em auxiliar no processo eleitoral de transição democrática, o que sendo realizado nos moldes liberais abrirá maior espaço para o livre mercado. Caso seja consolidado um regime democrático, não será mais um impasse, como o foi no governo Lula, manter laços com a Líbia.

\section{6}

\section{Conclusão}

Por se tratar de eventos extremamente recentes e principalmente pelo contexto político ainda muito instável na Líbia, qualquer quadro definitivo seria precoce. Além disso, a Cooperação Sul-Sul carece de institucionalização dificultando seu mapeamento, especialmente no caso da cooperação brasileira com a Líbia. No entanto algumas considerações preliminares são possíveis:

Primeiramente, a Cooperação Sul-Sul não deve ser vista unicamente como trocas econômicas ou de expertise, mas também com um instrumento de contestação do status quo do sistema internacional tanto do ponto de vista econômico quanto simbólico. A cooperação do Brasil com a Líbia e também com outros países árabes, reflete bem o teor contestatório da cooperação que levou a política externa brasileira ao impasse das "duas fortes aspirações conflitantes" como definiu Amar (2014).

Nesse sentindo o "espírito do não alinhamento" que segundo Elodie Brun (2008) é caracterizado pelo desejo de autonomia, ampliação do espaço de ação no cenário internacionais; a rejeição da ingerência estrangeira e está fortemente presente na ideia de Sul Global por vezes entra em conflito com o papel de "potência emergente", ator global e empreendedor normativo que o Brasil almeja. 
Em segundo lugar, a crítica do Brasil à intervenção da OTAN na Líbia não se restringe à crítica da implementação da Responsabilidade de Proteger. A despeito do ensaio de elaboração dos princípios da RwP, este trabalho aponta que existem desde longa data interesses políticos e econômicos do Brasil na Líbia. Portanto, o posicionamento brasileiro neste caso não deve ser observado unicamente à luz de questões humanitárias e de segurança.

Além da cooperação observada desde a década de 1970 e que é impulsionada durante o governo Lula, há de se observar atentamente as iniciativas do governo Dilma no período pós conflito na Líbia. Os envios de comissão parlamentar para o auxílio na transição política bem como de comissão empresarial revelam movimentos significativos no intuito de preparar o terreno para que os interesses brasileiros na região sejam mantidos ou reordenados na nova reconfiguração da política doméstica Líbia. Portanto, a inserção de potências emergentes em regiões de conflito e pós conflito precisa ser analisada com mais atenção pela literatura das Relações Internacionais focadas no nexo segurançadesenvolvimento.

E por fim, é possível observar não somente a ênfase da política externa brasileira na prevenção de conflitos, mas principalmente em dar enfoque e se movimentar no contexto da agenda Sul-Sul de desenvolvimento, onde sua margem de ação é seguramente maior, do que na agenda de segurança.

Nesse sentido, podemos indicar a perspectiva da política externa brasileira em que o desenvolvimento tem maior independência em relação à segurança, conferindo uma autonomia maior da agenda do desenvolvimento contrariamente à tendência examinada por Duffield (2012) onde o desenvolvimento é constantemente observado à luz da segurança. Por esse motivo talvez seja possível inverter a lógica do "nexo segurança-desenvolvimento", na perspectiva das potências do Norte Global, para a lógica "nexo desenvolvimento-segurança" a partir da perspectiva das potências emergentes do Sul Global que nesta relação parecem privilegiar e priorizar o desenvolvimento.

As críticas da PEB à lógica da Paz Liberal são evidentes, no entanto, seria incorrer em determinismos afirmar total afastamento da PEB a esta lógica, da mesma forma que seria incorreto afirmar total aproximação. A despeito das críticas à Paz Liberal o caso das relações entre Brasil e Líbia revela projetos importantes voltados para o desenvolvimento, embora não sejam fortemente coordenados nem 
institucionalizados. Compreender os interesses geopolíticos e econômicos que mobilizam tais projetos orientará o aprofundamento desse debate. 


\section{5}

\section{Considerações Finais}

Inserindo-se no marco teórico security-develoment nexus esta dissertação objetivou compreender a articulação do nexo segurança-desenvolvimento a partir da conjugação de discurso e prática proposta por David Chandler (2007) e Simon Reid-Henry (2011). Chandler (2007) propõe que os debates e tentativas de compreensão sobre o nexo entre Segurança e Desenvolvimento têm elaborado críticas no sentido de apontar que o nexo reflete um movimento de solução de problemas (problem-solving) e busca por manutenção do status quo na medida em que os Estados do Norte enxergam a pobreza dos países do Sul como uma ameaça à sua segurança.

$\mathrm{O}$ autor aponta que tais abordagens têm separado a retórica política da prática política gerando um movimento que ele conceituou como "anti-política externa" (anti-foreign policy). Nesse sentido, afirma que em grande medida as críticas ao nexo segurança-desenvolvimento perdem a dimensão da prática ao compreendê-lo sempre à luz da condenação à política externa dos países ocidentais.

Na mesma direção, Reid-Henry (2011) propõe um modelo metodológico alternativo ao proposto por Stern e Ojendal (2010) enxergando três principais lacunas no método do mapeamento de narrativas. A primeira é o direcionamento ao foco regional que se concentra nos países em desenvolvimento. Evidentemente, o nexo desenvolvimento-segurança tem sua referência principal o Sul Global, mas uma visão regional mais abrangente encontraria o nexo em locais como as exrepúblicas soviéticas, por exemplo. A segunda lacuna se encontra em uma visão focada unicamente em questões relacionadas a desenvolvimento e segurança enquanto que o nexo segurança-desenvolvimento também é encontrado em outros domínios como a economia. E por fim, a visão de que o nexo é uma espécie de alavanca através da qual se estabelece uma relação verticalizada em: “ 'we' have a control of 'them "'. Esse movimento pode ser de fato verificado, mas é vital também observar os impactos do nexo para aqueles que buscam implementá-lo. 
De modo geral, a discussão que permeia o nexo segurança-desenvolvimento traz à tona o debate acerca de padrões de desenvolvimento, mais precisamente acerca da transplantação/imposição de um modelo de desenvolvimento ocidental em situações de conflito e instabilidade através das práticas de peacebuilding. No entanto, tais discussões não contemplam a análise de como as potências emergentes articulam o nexo em suas práticas de cooperação para o desenvolvimento em situações de conflito e pós-conflito.

Alguns recentes estudos têm se concentrado em analisar o nexo nessa direção e esta dissertação objetiva contribuir para o aprofundamento desse debate. Além de utilizar a orientação teórica- metodológica dos autores acima citados buscou-se compreender o nexo a partir da perspectiva do mundo em desenvolvimento. $\mathrm{O}$ debate sobre o nexo segurança-desenvolvimento motivado pelo processo de securitização do desenvolvimento no contexto pós Guerra Fria (Duffield, 2010) e intensificado no pós 11 de setembro (Stern e Ojendal, 2010) tem o foco direcionado sobre a análise de como as potências do Norte articulam a interseção segurança-desenvolvimento, como foi apontado no início deste trabalho. No entanto, os questionamentos acerca das mudanças no papel das potências emergentes nos campos da segurança e desenvolvimento internacionais bem como suas reivindicações por reforma na governança global têm desafiado e ampliado o debate.

Como as potências emergentes articulam o nexo? Abdenur e Souza-Neto (2014) apontam um posicionamento crítico de alguns países do Sul a respeito de como o nexo é articulado como um legitimador de práticas intervencionistas por parte dos países do Norte, mas também apontam abordagens e perspectivas alternativas de interseção do nexo a partir das potências emergentes:

In Africa, some analysts argue that the security-development nexus representes na attempt by the aid industry to braden its own mandate, and/or as a way of liberaldemocratic states to legitimize forms of intervetionism (including of the military type) that flaunt the norms of multilateral regimes - a $n$ approach that may ultimately exacerbate inequalitites between North and South (Duffield, 2010). Some of these criticisms have yielded attempts to identify alternative perspectives on the intersection of securitya and development, including approaches unique to certain rising powers, such as the BRICS countries (Neethling e Hudson apud Abdenur e Souza-Neto (2014) 
Nesse sentido, a proposta apresentada nesta dissertação foi analisar o nexo a partir da perspectiva de uma potência emergente o compreendendo enquanto discurso e prática sem despolitizar ou esvaziar a crítica. Sugeriu-se, portanto, conduzir o debate de modo a compreender como a política externa brasileira operacionaliza na retórica e na prática a interseção entre segurança e desenvolvimento a partir de sua relação com a Líbia.

Nesse sentido, o objetivo central desta dissertação central foi analisar a Cooperação Sul-Sul entre o Brasil e a Líbia durante os governos Lula e Dilma dando destaque à observação da política externa brasileira e os esforços do Brasil em se inserir no cenário internacional enquanto potência emergente compreendendo este movimento sob o marco da interseção entre políticas de desenvolvimento e segurança.

Partindo da questão central "Em que medida a cooperação para o desenvolvimento oferecida à Líbia pelo Brasil corresponde ao discurso oficial da diplomacia brasileira no que diz respeito às intervenções humanitárias?” foram mapeados e identificados as frentes de cooperação estabelecida entre Brasil e Líbia, os atores envolvidos e os interesses econômicos e geopolíticos envolvidos na relação Brasil e Líbia, bem como foram analisadas as transformações da política externa brasileira no período compreendido no recorte temporal delimitado, e também foi proposta uma reflexão acerca de como o Brasil enquanto potência emergente entende a relação entre desenvolvimento e segurança.

Desse modo, confirmou-se a hipótese proposta em que a crítica do Brasil à intervenção da OTAN na Líbia não se restringe à crítica da implementação da Responsabilidade de Proteger. A despeito do ensaio de elaboração dos princípios da Responsabilidade ao Proteger este trabalho aponta que existem desde longa data interesses políticos e econômicos do Brasil na Líbia despolitizados pelo discurso humanitário. Portanto, o posicionamento brasileiro neste caso não deve ser observado unicamente à luz de questões humanitárias e de segurança.

Desde a década de 1970 o Brasil e a Líbia estabeleceram movimentos de cooperação significativos impulsionados pela crise energética mundial. Em um panorama histórico e de análise da política externa brasileira nesse período observou-se que as relações entre os dois países não obedeceram um continuum, ao 
contrário, foram marcadas por movimentos de aproximação e afastamento, encontros e desencontros.

Também foi possível notar que em todas as fases de aproximação entre os dois países o comércio do petróleo teve papel fundamental de motivador da intensificação das relações. Além disso, coube destacar que na fase iniciada com o governo Lula, tais relações foram inseridas como parte do projeto de priorização da Cooperação Sul-Sul pela política externa brasileira.

Alguns movimentos conclusivos foram propostos com a ressalva de que se tratando de eventos extremamente recentes e principalmente pelo contexto político ainda muito instável na Líbia, qualquer quadro definitivo seria precoce. Além disso, cabe destaque o fato de que a Cooperação Sul-Sul carece de institucionalização.

Existe uma multiplicidade de atores envolvidos na Cooperação Sul-Sul, públicos e privados, no entanto, há uma deficiência de canais institucionalizados que representem tal diversidade (Milani, 2014). A Cooperação Técnica para o Desenvolvimento (CTPD) por ser coordenada por uma série de atores estatais como a Agência Brasileira de Cooperação, apresenta um maior grau de institucionalização, mas ainda assim há uma dispersão institucional bem como inexistência de marcos regulatórios próprios. (Leite et al.2013).

O único movimento de Cooperação Técnica entre o Brasil e a Líbia registrado e apresentado no último capítulo foi articulado pelo Ministério da Saúde, mas não foi levado adiante. A cooperação do Brasil com a Líbia se dá de forma desarticulada e bastante diversa dificultando seu mapeamento. Nesse sentido, a cooperação brasileira com a Líbia é consideravelmente menos institucionalizada comparando-se com a cooperação brasileira com os países da região da África subsaariana, forte caracterizada pela Cooperação Técnica para o Desenvolvimento. Feitas as devidas ressalvas, seguem os esforços conclusivos encaminhados em três direções.

Primeiramente, a Cooperação Sul-Sul não deve ser vista unicamente como trocas econômicas ou de expertise, mas também com um instrumento de contestação do status quo do sistema internacional tanto do ponto de vista econômico quanto simbólico. Porém ao mesmo tempo em que se caracteriza pela contestação marca o objetivo cada vez mais flagrante de inserção no sistema internacional. A cooperação do Brasil com a Líbia e também com outros países árabes, reflete bem o teor contestatório e ao mesmo tempo de inserção da 
cooperação que levou a política externa brasileira ao impasse das "duas fortes aspirações conflitantes" como definiu Amar (2014).

Nesse sentido, há uma dinâmica conflitiva e crescente na política externa brasileira que alterna contestação do e inserção no sistema internacional. Essa dinâmica permeia as relações do Brasil com a Líbia bem como o posicionamento brasileiro no que tange às agendas de desenvolvimento e segurança. Às "duas aspirações conflitantes" me refiro ao definir a dinâmica antética de contestação e inserção muito claras na atuação internacional do Brasil no marco do nexo desenvolvimento-segurança.

Nesse sentindo o "espírito do não alinhamento" que segundo Elodie Brun (2008) é caracterizado pelo desejo de autonomia, ampliação do espaço de ação no cenário internacionais; a rejeição da ingerência estrangeira e está fortemente presente na ideia de Sul Global por vezes entra em conflito com o papel de "potência emergente", ator global e empreendedor normativo que o Brasil almeja.

Em segundo lugar, partindo da premissa de que os interesses brasileiros na Líbia são despolitizados pelo discurso humanitário da RwP, que por sua vez não deve ser analisada unicamente a luz da segurança, notou-se que além da cooperação observada desde a década de 1970 e que é impulsionada durante o governo Lula, há de se observar atentamente as iniciativas do governo Dilma no período pós conflito na Líbia.

Os envios de comissão parlamentar para o auxílio na transição política bem como de comissão empresarial revelam movimentos significativos no intuito de preparar o terreno para que os interesses brasileiros na região sejam mantidos ou reordenados na nova reconfiguração da política doméstica Líbia. Portanto, a inserção de potências emergentes em regiões de conflito e pós conflito precisa ser analisada com mais atenção pela literatura das Relações Internacionais focadas no nexo segurança-desenvolvimento.

E por fim, este trabalho aponta que é possível observar não somente a ênfase da política externa brasileira na prevenção de conflitos, mas principalmente em dar enfoque e se movimentar no contexto da agenda Sul-Sul de desenvolvimento, onde sua margem de ação é seguramente maior, do que na agenda de segurança.

Nesse sentido, pode-se indicar a perspectiva da política externa brasileira em que o desenvolvimento tem maior independência em relação à segurança, conferindo uma autonomia maior da agenda do desenvolvimento contrariamente à 
tendência examinada por Duffield (2012) onde o desenvolvimento é constantemente observado à luz da segurança. Por esse motivo talvez seja possível inverter a lógica do "nexo segurança-desenvolvimento", na perspectiva das potências do Norte Global, para a lógica "nexo desenvolvimento-segurança" a partir da perspectiva das potências emergentes do Sul Global que nesta relação parecem privilegiar e priorizar o desenvolvimento.

As críticas da PEB à lógica da Paz Liberal são evidentes, no entanto, seria incorrer em determinismos afirmar total afastamento da PEB a esta lógica, da mesma forma que seria incorreto afirmar total aproximação. A despeito das críticas à Paz Liberal o caso das relações entre Brasil e Líbia revela projetos importantes voltados para o desenvolvimento, embora não sejam fortemente coordenados nem institucionalizados.

Este trabalho procurou preencher lacunas de ordem teórica e empírica. Da perspectiva teórica foi feito um esforço de inserir a perspectiva das "potências emergente" enquanto interventoras no debate acerca do nexo segurançadesenvolvimento. Da perspectiva empírica, observou-se que os trabalhos realizados acerca de Cooperação Sul-Sul brasileira têm enfoque voltado para a cooperação com os países da África Subsaariana, sendo portanto esta dissertação um esforço de contribuição para o debate nesse sentido.

Como o Brasil se relaciona com outros países do Norte da África? Quais as possíveis comparações entre a Cooperação Sul-Sul brasileira no Norte da África e na África Subsaariana? Como o Brasil articula no discurso e na prática o nexo segurança-desenvolvimento em outras regiões? Essas são lacunas ainda não preenchidas por este trabalho, mas que apontam direções futuras para o aprofundamento do tema. 


\section{Referências Bibliográficas}

ABC - Banco ABC Brasil - Disponível em: http://www.abcbrasil.com.br/show.aspx?idCanal=yy8GhdCZO4Z8I1bQoASoFw= = Acessado em: 21 de julho de 2014 .

ABDENUR, Adriana e SOUZA NETO, Danilo Marcondes de. Beyond China and Africa: a focus on Brazil. Democracy in Africa. 08 de junho de 2013.

Rising Powers and the Securit Development Nexus: Brazil's Engagement with Guinea-Bissau. Journal of Peacebuilding \& Development, Volume 9, Issue 2, pp. 1-16. 2014.

AHMIDA, Ali Abdullatif. Beyond Colonialism and Nationalism in the Maghrib. History, Culture and Politics. Palgrave. New York. 2007.

ALJAZEERA. Disponível em: http://blogs.aljazeera.com/blog/middle-east/liveblog-libya Acessado em: 23 de dezembro de 2012.

AMAR, Paul. The Middle East and Brazil. Perspectives on the New Global South. Indiana University Press. 2014.

AMER, Ramses, SWAIN, Ashok e ÖJENDAL,Joakim. Security-Development Nexus. Anthem Press. London. 2012.

AMIN, Samir. Delinking: Towards a Policentric World. Londres e NovaYork: Zed Books. 1990.

AMORIM, Celso. Discursos, Palestras e Artigos do Chanceler Celso Amorim Volume I - Departamento de Comunicação e Documentação - Ministério das Relações Exteriores - Brasília - 2011.

Brasil-Haiti - Programa de Cooperação Sul-Sul. Agência Brasileira de Cooperação - ABC.

ANBA Agência de Notícias Brasil-Árabe. Disponível em: http://www.anba.com.br/noticia/13387428/diplomacia/brasil-ajudara-libia-nareconstrucao/?indice=200 Acessado em 16 de outubro de 2013.

ANDERSON, Lisa. The State and Social Transformation in Tunisia and Libya. 1830-1980. Princeton University Press. New Jersey. 1986. 
. "Qadhafi's Legacy: An Evaluation in the Jamahiriyya". In: VANDEWALLE, Dirk. Qadhafi's Libya 1969 to 1994. San Martin's Press. New York. 1995.

Demistifying the Arab Spring. Foreign Affairs, p.2. maio/junho 2011.

ARAB BANKING CORPORATION - Disponível em: http://www.arabbanking.com/En/Pages/default.aspx Acessado em 21 de julho de 2014.

BBC Disponível em: http://www.bbc.co.uk/news/world-africa-12699183 Acessado em: 23 de dezembro de 2014.

BELLAMY, Alex. Responsability to Protect. Policy Press. Cambridge. 2009.

BENNER, Thorsten. Brazil as a norm entrepreneur: the "Responsability while Protecting” initiative. Global Public Policy Institute GPPI. Berlim. 2013.

BRUN, Elodie. Les Relations entre l'Amérique do Sud et el Moyen Orient. Un exemple de relance Sud-Sud. L'Harmattan. Paris. 2008.

BUUR, Lars, JENSEN, Steffen e STEPPUTAT, Finn. The Security-Development Nexus. Expressions of Sovereignty and Securitization in Southern Africa. HSRC Press. Cape Town. 2007.

CAMMETT, Melanie. Globalization and Business Politics in Arab North Africa. Cambridge University Press. New York. 2007.

CAMPBELL, Horace. Nato's failure in Libya. Africa Institute of South Africa. South Africa. 2012.

CAMPBELL Susanna, CHANDLER, David e SABARATNAM, Meera. A Liberal Peace? The problems and pactice of peacebuilding. New York. Zed Books. 2011.

CAMPOS, Pedro Henrique Pedreira. A Ditadura dos Empreiteiros: as empresas nacionais de ocntrução pesada, suas formas associativas e o Estado ditatorial brasileiro, 1964-1985. Universidade Federal fluminense. Niterói. 2012.

CASARÕES, Guilherme. Construindo Pontes? O Brasil diante da Primavera Árabe. Cienc. Cult. vol.64 no.4 São Paulo Oct./Dec. 2012.

CFR - COUNCIL OF FOREIGN RELATIONS - Disponível em: http://www.cfr.org/humanitarian-intervention/international-commission intervention-state-sovereignty-responsibility-protect-report/p24228 Acessado em 16 de outubro de 2013.

CHANDLER, David. The security-development nexus and the rise of 'anti-foreign policy'. Journal of International Relations and Development. 2007. 
CHIVVIS, Christopher S., CRANE, Keith, MANDAVILLE, Peter e MARTINI, Jeffrey. Libya's Post-Qaddafi Transition: The Nation-Building Challange. National Security Research Division. 2012.

CHRISTMAN, Henry. Qaddafi's Green Book. Prometheus Books, New York. 1988.

CPDOC/FGV: Centro de Pesquisa e Documentação de História Contemporânea do Brasil - Fundação Getúlio Vargas. Verbete: Centro de Estudos e Defesa do Petróleo e da Economia Nacional (CEDPEN)

CPDOC/FGV: Centro de Pesquisa e Documentação de História Contemporânea do Brasil - Fundação Getúlio Vargas Verbete: Petrobras

CODEFASV Disponível em: http://www.codevasf.gov.br/noticias/2006/baixio-deirece/?searchterm=Lafico Acessado em: 21 de julho de 2014.

DOYLE, Michael. Kant, Liberal Legacies, and Foreign Affairs. Philosophy \& Public Affairs, Vol. 12, No. 3. 1983

DUFFIELD, Mark. Global Governance and the New War. New York. Zed Books. 2001.

. Development, Security and Unending War. Governing the World of Peoples. Polity Press. Cambridge. 2007.

The Liberal Way of Development and the Development-Security Impasse: Exploring the Global Life-Chance Divide. Security Dialogue. 2010.

ELIZONDO, Gabriel. Aljazeera - Disponível em: http://blogs.aljazeera.com/blog/americas/brazils-business-libya Acessado em $23 \mathrm{de}$ novembro de 2014.

FARAH, Paulo. The Summit of South America-Arab States: Historical Contexts of South-South Solidarity and Exchange. In: AMAR, Paul. The Middle East and Brazil. Perspectives on the New Global South. Indiana University Press. 2014.

FELLET, João. $\quad$ BBC $\quad$-Disponível em http://www.bbc.co.uk/portuguese/noticias/2011/10/111020_brasil_libia_jf_rc.sht ml Acessado em: 16 de outubro de 2013.

FERREIRA, Carlos Henrique Ruiz. O Brasil enquanto membro não permanente no Conselho de Segurança das Nações Unidas no mandato 2010-2011.Programa de Cooperación en Seguridad Regional. Maio 2012.

GATESTONE INSTITUTE Disponível em: http://www.gatestoneinstitute.org/4251/libya-monarchy Acessado em: 13 de janeiro de 2015. 
GODOY, Roberto Estadão. Disponível em: http://www.estadao.com.br/noticias/impresso,blindados-usados-pela-libia-saofornecidos-pelo-brasil,688430,0.htm Acessado em: 16 de outubro de 2013.

GONÇALVES, Williams da Silva, MIYAMOTO, Shiguenoli. Os militares na políitca externa brasileira: 1964-1984. Estudos Históricos. Rio de Janeiro. Vol 6, n.12. 1993.

GLOBAL R2P ORG Disponível em:http://www.globalr2p.org/media/files/ungasyriaaug3.pdf Accessado em: 02 de novembro de 2013.

HAERI, Safa. Asia Times Online. Disponível em: http://www.atimes.com/atimes/Middle_East/FC04Ak06.html Acessado em: 03 de fevereiro de 2015.

HAMANN, Eduarda e MUGGAH, Robert. A Implementação da Responsabilidade de Proteger: novos rumos para a paz e a segurança internacional?. Instituto Igarapé. Brasília. 2013.

HIRST, Mônica, LIMA, Maria Regina Soares e PINHEIRO, Letícia. A Política Externa Brasileira em Tempos de novos Horizontes e Desafios. Nueva Sociedad. 2010.

- e PINHEIRO, Letícia. A política externa do Brasil em dois tempos. Revista Brasileira de Política Internacional.38 (1): 5-23. 1995.

HURREL, Adrew. Brazil and The New Global Order. Current History 109:724: 6066.

IKENBERRY, John e WRIGHT, Thomas. Rising Powers and Global Institutions. The Century Foundation, New York. 2008.

IPEA “Além da autossuficiência: o Brasil como protagonista no setor energético.". Abril, 2012.

IVAN, Richard EBC- Agência Brasil -Disponível em: http://agenciabrasil.ebc.com.br/internacional/noticia/2014-07/itamaraty-transfereembaixada-da-libia-para-tunisia-por-falta-de Acessado em: 07de janeiro de 2015.

JORNAL DO BRASIL - Acervo - Disponível em: http://memoria.petrobras.com.br/upload/acervo/contratos-de-risco-para-explorarpetroleo-no-brasil-sao-autorizados28/1975\%20set\%2026_Jornal\%20do\%20Brasil_Petr\%C3\%B3leo\%20e\%20Kafta. pdf Acessado em: 06 de janeiro de 2015.

JUBILUT, Liliana Lyra. A "Responsabilidade de Proteger" é uma mudança real para as intervenções humanitárias? USP. São Paulo. 2007.

JUSBRASIL Decreto $\mathrm{n}^{\mathrm{o}} 4.865$ - Disponível em: http://www.jusbrasil.com.br/topicos/10975873/artigo-1-do-decreto-n-4865-de-29de-outubro-de-2003. Acessado em 12 de janeiro de 2014. 
JUSBRASIL-Disponível

em:

http://jb.jusbrasil.com.br/definicoes/100000159/contrato-de-risco?ref=home Acessado em: 27 de janeiro de 2015.

JUSBRASIL Disponível em:http://congresso-emfoco.jusbrasil.com.br/politica/6771004/manchetes-dos-jornais-dilma-modificapolitica-de-lula-e-vota-contra-o-ira Accessado em: 03 de dezembro de 2013.

KENKEL, Kai Michael, $4^{\circ}$ Encontro Nacional da Associação Brasileira de Relações Internacionais. Belo Horizonte. 2013.

Brazil and R2P: Does Taking Responsibility Mean Using Force? Global Responsibility to Protect, v. 4, p. 5-32, 2012.

. Brazil's Peacekeeping and Peacebuilding Policies in Africa Journal of International Peacekeeping 272-292. 2013.

LAESSING, Ulf, AL-WARFALLI, Ayman e BOSALUM, Feras - Reuters Diponível em: http://br.reuters.com/article/businessNews/idBRSPEA3501I20140406 Acessado em: 08 de janeiro de 2015.

LEITE, Iara Costa. Cooperação Sul-Sul: Conceito, História e Marcos Interpretativos. Observador On-line v.7, n.03, mar. 2012.

Cooperação Sul-Sul: um ensaio conceitual. 2010.

SUYAMA, Bianca e WAISBICH, Laura. Para além do tecnicismo:a Cooperação Brasileira para o Desenvolvimento Internacional e caminhos para sua efetividade e democratização.Articulação Sul. Policy Brief. Julho 2013.

LEITE, Patrícia. O Brasil e a Cooperação Sul-Sul em três momentos de política externa: os governos de Jânio quadros/João Goulart, Ernesto Geisel e Luiz Inácio Lula da Silva. Brasília. Fundação Alexandre de Gusmão - FUNAG. 2011.

LIMA, Maria Regina Soares. A política externa brasileira e os desafios da cooperação Sul-Sul. Rev. Bras. Polít. Int. 48 (1): 24-59 2005.

LUZ DA, Natalia. Por dentro da África - Disponível em: http://www.pordentrodaafrica.com/negocios/queremos-desenvolver-uma-parceriaimportante-com-o-brasil-diz-ministro-do-petroleo-da-libia Acessado em 13 de janeiro de 2015.

MARIN, Denise Estadão Disponível em: http://economia.estadao.com.br/noticias/economia-geral,exploracao-de-gas-dexisto-nos-estados-unidos-inicia-revolucao-energetica,160917,0.htm Acessado em 06 de fevereiro de 2014. 
MAWDSLEY, Emma. From recipients to donors: Emerging powers and the changing development landscape. London: Zed Books, 2012.

MILANI, Carlos R. S.; CARVALHO, T. C. O.. Cooperação Sul-Sul e Política Externa: Brasil e China no Continente Africano. Estudos Internacionais: revista de relações internacionais da PUC Minas, v. 1, p. 11-35, 2013.

Brazil's South-South Co-operation Strategies: From Foreign Policy to Public Policy. South African Institute of International Affairs. Março, 2014.

MONTIBELER, Everlan Elias e GALLEGO, Esther Solano. Relaciones bilaterales entre Brasil y Liga Árabe: un análisis a partir de la teroría de la internacionalización de la producción y de la diversificación comercial. Observatorio de la Economía Latinoamericana, $\mathrm{n}^{\circ} 163,12$ pp. 2012.

MRE - Ministério das Relações Exteriores - - Sistema Atos Internacionais. Disponível em: http://dai-mre.serpro.gov.br/atosinternacionais/bilaterais/1978/b_48/ Acessado em: 23 de outubro de 2014.

MRE Ministério das Relações Exteriores - Itamaraty Disponível em: http://www.itamaraty.gov.br/index.php?option=com_content\&view=article\&id=3

675: cupula-america-do-sul-paises-arabes-aspa\&catid=172\&lang=pt-

br\&Itemid=436 Acessado em: 10 de janeiro de 2015.

MRE - Ministério das Relações Exteriores. Protocolo de Intenções entre o Governo da República Federativa do Brasil e a Grande Jamaíria Árabe popular Socialista da Líbia sobre Cooperação Técnica na Área da Saúde. 2009. Disponível em: http://daimre.serpro.gov.br/atos-internacionais/bilaterais/2009/b_6290/ Acessado em: $16 \mathrm{de}$ outubro de 2013.

MRE - Ministério das Relações Exteriores. Disponível em: http://www.itamaraty.gov.br/sala-de-imprensa/notas-a-imprensa/participacao-doministro-das-relacoes-exteriores-antonio-de-aguiar-patriota-em-debate-sobreresponsabilidade-aoproteger-na-onu-2013-nova-york-21-de-fevereiro-de2012/print-nota Acessado em 04 de julho de 2014.

MRE - Ministério das Relações Exteriores - Itamaraty Disponível em: http://www.itamaraty.gov.br/index.php?option=com_content\&view=article\&id=5 379\&Itemid=478\&cod_pais=LBY\&tipo=ficha_pais\&lang=pt-br Acessado em: 03 de fevereiro de 2015.

MRE - Ministério das Relações Exteriores do Brasil - Itamaraty. Disponível em: http://diplomaciapublica.itamaraty.gov.br/63-representante-especial-do-brasil-eacreditado-junto-a-liga-dos-estados-arabes. Acessado em: 03 de novembro de 2014.

MRE - Minitério das Relações Exteriores - Presidente da Repúlbica Federativa do Brasil - Discursos. Disponível em: http://www.itamaraty.gov.br/index.php?option=com_content\&view=article\&id=4 650:discurso-da-presidenta-da-republica-dilma-rousseff-durante-reuniao-plenaria- 
da-v-cupula-do-ibas-pretoria-africa-do-sul-18-10-

2011\&catid=197\&Itemid=448\&lang=pt-br Acessado em 18 de outubro de 2013.

NAPOLITANO, Giuliana. ANBA - Agência de Notícias Brasil-Árabe. Disponível em: http://anba.com.br/noticia/7390980/especiais/estatal-libia-negocia-jointventure-com-odebrecht-e-andrade-gutierrez/?indice=20. Acessado em:21 de julho de 2014.

NEVES, Gilda Motta Santos. Comissão das Nações Unidas para Consolidação da Paz -Perspectiva Brasileira. FUNAG. Brasília. 2010.

ONU - ORGANIZAÇÃO DAS NAÇÕES UNIDAS - UNICEF - Brasil. Disponível em: http://www.unicef.org/brazil/pt/resources_10134.htm Acessado em:05 de novembro de 2013.

PAC - Programa de Aceleração do Crescimento -Ministério do Planejamento Disponível em: http://www.pac.gov.br/obra/8071 Acessado em: 21 de julho de 2014.

PACK, Jason. The Center and the Periphery. The 2011 Libyan Uprisings and The Struggle for the Post-Qadhafi Future. Palgrave Macmilliam. New York. 2013.

PARGETER, Alison. Libyan the Rise and Fall of Qaddafi. Yale University Press. New Heaven and London. 2012.

PARIS, Roland e SISK, Timothy. The Dilemma of Statebuilding. Confronting the Contradictions of Postwar Peace Operations. Routledge. London e New York. 2009.

PETROBRAS

Disponível

em: http://www.petrobras.com/pt/paises/libia/libia.htm Acessado em 21 de julho de 2014.

PINAR, Tank. NOREF Policy Brief "The concepto of Rising Poers" Norwegian Peacebuilding Resource Center. Junho de 2012.

PINHEIRO, Letícia. Foreign Policy Decision-Making under Geisel Government. FUNAG, Brasília. 2013.

PRASHED, Vijay. The Darker Nations. The New Press. New York and London. 2007.

Arab Spring, Libyan Winter. AK Press. Oakland and Endimburgh. 2012.

PREISS, José Luiz Silva. Brasil e Argentina no Oriente Médio: do PósSegunda Guerra Mundial ao final da Guerra Fria / José Luiz Silva Preiss. - Porto Alegre, 2013.

PRESIDÊNCIA DA REPÚBLICA. SECRETARIA DE IMPRENSA E DIVULGAÇÃO. Discurso do Presidente da República, Luiz Inácio Lula da Silva, 
na visita à sede da Liga dos Estados Árabes Cairo-Egito, 09 de dezembro de 2003. Disponível em:http://www.biblioteca.presidencia.gov.br/ex-presidentes/luizinacio-lula dasilva/discursos/1o-mandato/pdfs-2003/2o-semestre/09-12-2003discurso-do-presidente-da-republica-luiz-inacio-lula-da-silva-na-visita-a-sede-daliga-dos-estados-arabes Acessado em: 10 de janeiro de 2015.

REID-HENRY, Simon. Spaces of security and development: An alternative mapping of the security-development nexus. Security Dialogue. 2011.

REUTERS - $\quad$ Disponível em: http://br.reuters.com/article/topNews/idBRSPE77M0SF20110823 Acessado em: 08 de janeiro de 2015.

RICHMOND, Oliver. "The problem of peace: understanding the 'liberal peace". Conflict, Security \& Development 6:3 October. 2006.

_. The transformation of Peace. Palgrave, Macmillan. Hampshire.2007.

Peace in International Relations. Routledge. London e New York. 2008.

. A Post-Liberal Peace. Routledge Tayloe \& Francis Group. Oxon. 2011.

RODRIGUES, Fernando Folha de São Paulo - Disponível em: http://www1.folha.uol.com.br/folha/brasil/ult96u56038.shtml

Consultado em 30 de outubro de 2013.

ROSA, Luciano 1996, 443-444 In. AMAR, Paul. The Middle East and Brazil. Indiana University Press. 2014.

SANTANA, Carlos Ribeiro. O aprofundamento das relações do Brasil com os países do Oriente Médio durante os dois choques do petróleo da década de 1970: um exemplo de ação pragmática. Rev. Bras. Polít. Int. 49 (2): 157-177. 2006.

Brazil's Relations with the Middle East in the "Oil Shock" Era: Pragmatismo, Universalism, and Developmentalism in the 1970's In: The Middle East and Brazil: Perspectives on the new Global South org. AMAR, Paul. Indiana University Press. Indiana. 2014.

SAWANI, Youssef Mohammed. Dynamics of Continuity and Change. In: PACK, Jason. The 2011 Libyan Uprisings and The Struggle for the Post-Qadhafi Future. Palgrave Macmilliam. New York. 2013.

SENADO - Contrato com Cláusula de Risco para Exploração de Petróleo no Brasil. Disponível em: http://www2.senado.leg.br/bdsf/bitstream/handle/id/176365/000499438.pdf?seque nce $=1$ Acessado em: 27 de janeiro de 2015 .

SENADO Notícias - Disponível em: http://www2.senado.leg.br/bdsf/bitstream/handle/id/48724/noticia.htm?sequence= 1 Acessado em: 08 de janeiro de 2015. 
SHANE, Scott. The New York Times Disponível em: http://www1.folha.uol.com.br/fsp/newyorktimes/ny1011201105.htm Acessado em 04 de julho de 2014.

SILVA, Daniele Dionísio da. Operações de paz à brasileira - uma reflexão teórica, contextual e historiográfica. Um estudo de caso da minustah. 2012.

SPEKTOR, Matias. Origens e direção do Pragmatismo Ecumênico e Rsponsável (1974-1979).Revista Brasileira de Política Internacional. 47 (2): 191-222. 2004.

ST JOHN, Bruce Ronald. The Post-Qadhafi Economy. In: PACK, Jason. The 2011 Libyan Uprisings and The Struggle for the Post-Qadhafi Future. Palgrave Macmilliam. New York. 2013.

STERN, Maria e OJENDAL Joakim. Mapping the Security-Development Nexus: Conflict, Complexity, Cacophony, Convergence? Security Dialogue, 2010.

TAYLOR, Ian. China's New Role in Africa Boulder, Colorado: Lynne Rienner, 2009.

UNITED NATIONS - UNSCR Security Council S/RES/1973 (2011) 17 Março de 2011. Disponível em: http://www.nato.int/nato_static/assets/pdf/pdf_2011_03/20110927_110311-

UNSCR-1973.pdf Acessado em: 10 de fevereiro de 2014.

UNITED NATIONS - UNSCR Security Council Disponível em: http://www.nato.int/nato_static/assets/pdf/pdf_2011_02/20110927_110226UNSCR-1970.pdf Acessado em: 16 de outubro de 2013.

URT, João Nackle. A lógica da construção de confiança: Relações BrasilSuriname entre 1975 e 1985. Rev. Bras. Polít. Int. 53 (2): 70-87 [2010]

VANDEWALLE, Dirk. Qadhafi's Libya 1969 to 1994. St. Martin's Press. New York. 1995. 1998.

Libya Since Independence. Cornell University Press. Ithaca and London.

VIGEVANI, Tullo, OLIVEIRA, Marcelo e CINTRA, Rodrigo. Política externa no período FHC: a busca de autonomia pela integração. Tempo Social USP. São Paulo. 2003.

. e CEPALUNI, Gabriel. Política Externa Brasileira: a busca de autonomia, de Sarney a Lula. São Paulo, Ed. Unesp, cap.2 2011.

VIZENTINI, Paulo Fagundes. A Política Externa no Regime Militar Brasileiro: multilateralização, desenvolvimento e construção de uma potência média. 19641985. Editora UFRGS. Rio Grande do Sul. 2004. 
YILMAZ, Muzaffer Ercan. Peacebuilding in Libya. International Journal on World Peace. Vol. XXIX n. 1. 2012.

WALTZ, Kenneth. Theory of International Politics. New York: McGraw-Hill,Inc., 1976.

WEISS , Thomas G. e THAKUR Ramesh, Global Governance and the UN: An Unfinished Journey Bloomington: Indiana University Press, 2010.

ZARTMAN, William. Political Elites in Arab North Africa. Longman. New York and London. 1982. 